\title{
Efeitos das atividades diárias nos níveis de sonolência, em estudantes do Ensino Médio, trabalhadores e não-trabalhadores
}

\section{Liliane Reis Teixeira}

Tese apresentada ao Programa de PósGraduação em Saúde Pública da Faculdade de Saúde Pública da Universidade de São Paulo para obtenção do título de Doutor em Saúde Pública.

Área de Concentração: Saúde Ambiental Orientadora: Prof ${ }^{\mathrm{a}}$. Dra. Frida Marina Fischer

São Paulo

2006 
É expressamente proibida a comercialização deste documento, tanto na sua forma impressa como eletrônica. Sua reprodução total ou parcial é permitida exclusivamente para fins acadêmicos e científicos, desde que na reprodução figure a identificação do autor, título, instituição e ano da tese. 


\section{DEDICATÓRIAS}

Ao Wagner,

Por ter sido ele, o primeiro a enxergar minha verdadeira vocação.

Aos meus pais, pelo amor e compreensão 


\section{AGRADECIMENTOS}

À Profa. Frida Marina Fischer, minha orientadora, pelo carinho e pela preocupação dedicada a mim e a todos os seus alunos durante todos esses anos.

Ao Prof. Arne Lowden, meu co-orientador, pela hospitalidade e colaboração na análise dos dados e elaboração dos artigos.

À Profa. Maria do Rosário Dias de Oliveira Latorre pelo auxílio na análise dos dados.

À Profa.Claudia Roberta de Castro Moreno pelas sugestões e auxílio na análise dos dados.

À Samantha Lemos Turte pelo grande apoio durante todo o desenvolvimento deste trabalho.

À Flavio Notarnicola da Silva Borges, Roberta Nagai, Lilian Cardoso de Souza Zinn, Josiane Steluti e Nilson Silva Soares pela amizade e apoio na coleta de dados.

Aos adolescentes, que continuam sendo a minha inspiração e aos que participaram deste estudo, agradeço o esforço e dedicação.

À Direção, aos professores e funcionários da Escola Estadual Fernão Dias Paes, pelo apoio, colaboração e compreensão.

À Direção e funcionários da Faculdade de Saúde Pública da Universidade de São Paulo, pelo apoio financeiro e administrativo.

À Pró-reitoria de Pós-Graduação e à Pró-Reitoria de Pesquisa da Universidade de São Paulo pelo apoio financeiro e administrativo.

A todos os pesquisadores e funcionários do Instituto Karolinska - "Institute for Psychosocial Medicine" pela atenção dedicada e pelo auxílio no meu aperfeiçoamento acadêmico.

À Fundação de Amparo à Pesquisa do Estado de São Paulo (FAPESP, processo ${ }^{0}$ 02/04079-6), ao CNPq (processo $\mathrm{n}^{\circ}$ 140846/2003-4; 470917/2003-2 e 500124/2003-5) e a CAPES (processo ${ }^{0}$ 3202/04-6) pelos recursos financeiros concedidos, essenciais para a realização do trabalho.

A todos que colaboraram para a realização deste trabalho, direta ou indiretamente, meus sinceros agradecimentos. 
Teixeira LR. Efeitos das atividades diárias nos níveis de sonolência, em estudantes do Ensino Médio, trabalhadores e não-trabalhadores [tese de doutorado]. São Paulo: Faculdade de Saúde Pública da USP; 2006.

\section{RESUMO}

Introdução - A sonolência é descrita como a interação entre o momento circadiano para adormecer e o aumento da necessidade de sono, e está em geral, associada ao decréscimo do alerta, do tempo de reação, da memória, da coordenação psicomotora, do entendimento da informação, do tempo para se tomar decisões, da maior incidência de uso de substâncias estimulantes e de substâncias álcoolicas. Na adolescência, a sonolência limita as perspectivas dos adolescentes quanto ao seu desenvolvimento intelectual. Muito pouco se conhece sobre a percepção da sonolência em estudantes trabalhadores. Objetivo - Verificar variações da sonolência ao longo do dia e o possível impacto das atividades diárias e estilos de vida na sonolência em estudantes. Metodologia - A população estudada compreendem estudantes trabalhadores e não-trabalhadores, alunos do ensino médio do período noturno de uma escola pública estadual da cidade de São Paulo, SP. Participaram estudantes entre 14 e 21 anos de idade incompletos. Os estudantes selecionados preencheram os questionários de: caracterização das condições de vida, saúde e sono, matutinidade-vespertinidade, caracterização das condições de trabalho e freqüência alimentar. Em seguida foi realizada a obtenção de registros sobre o ciclo vigília-sono dos estudantes através de métodos subjetivos (Protocolo diário de atividades, diário de sono e escala de sonolência) e objetivos (Actimetria). As variáveis sócio-demográficas, estilos de vida, condições de trabalho e do ciclo vigília-sono foram testadas através do teste tStudent, ANOVA para três fatores (dia da semana, horário e trabalho), QuiQuadrado de Pearson $\left(\chi^{2}\right)$ e análise de regressão. Resultados - 1) a duração média do sono nos dias da semana para os estudantes trabalhadores foi em torno de $7 \mathrm{~h}$, enquanto a duração do sono dos estudantes não trabalhadores foi em torno de $9 \mathrm{~h}$; 2) os padrões de sonolência de estudantes trabalhadores são diferentes dos estudantes não-trabalhadores. Verificamos que os estudantes trabalhadores são mais sonolentos que os estudantes não-trabalhadores no primeiro registro diário 
(07 $09 \mathrm{~h})$ e no último $(22$ - $24 \mathrm{~h})$. Verificamos que os estudantes trabalhadores são mais sonolentos que estudantes não-trabalhadores na segunda-feira após o almoço $(13+15 \mathrm{~h})$, na quarta-feira durante as aulas $(19+21 \mathrm{~h})$ e na sexta-feira antes de dormir $(22+24 \mathrm{~h})$. Aos domingos, entre $22+24 \mathrm{~h}$ foi encontrada o maior nível de sonolência entre os estudantes trabalhadores. Também, neste momento, os trabalhadores são mais sonolentos que os estudantes não-trabalhadores em todos os outros dias e horários; 3) os fatores independentemente associados a estar sonolento foram: trabalhar, ser do sexo feminino, consumir álcool, ter maior dificuldade para adormecer e ir dormir após as $24 \mathrm{~h}$. Conclusões - Os padrões de sonolência de estudantes trabalhadores são diferentes dos estudantes nãotrabalhadores e as variáveis do ciclo vigília-sono interferem nos níveis de sonolência ao longo do dia. Além dos fatores cronobiológicos outros fatores estão relacionados às mudanças nos níveis da sonolência: a) fatores individuais; b) fatores sociais; c) fatores sócio-demográficos e d) estilos de vida. Essa gama de fatores acaba levando ao aumento da sonolência no início e fim do dia para os estudantes trabalhadores, podendo interferir no rendimento escolar e prejudicar o desenvolvimento físico e mental, característicos da adolescência. Programas de intervenção tais como, o conhecimento sobre a higiene do sono e as políticas de inserção social que permitam aos estudantes manter um padrão de vida adequado sem ter que sujeitar a longas jornadas de trabalho enquanto na adolescência, devem ser implementados.

Descritores: estudantes, estudantes trabalhadores, sonolência, ciclo vigília-sono, cronobiologia. 
Teixeira LR. Effects of daily activities in patterns of sleepiness among working and non-working high school students [doctoral thesis] in São Paulo: School of Public Health, University of São Paulo; 2006.

\section{ABSTRACT}

Introduction - Sleepiness is described as an interaction between the circadian phase and the increase in pressure to sleep. In general, it is associated with a decrease in alertness levels, reaction time, memory, psychomotor coordination, information assimilation, time to take decisions, and larger consumption of stimulant and alcoholic substances. In adolescence, sleepiness restricts the adolescent's perspectives as to his/her intellectual development. Knowledge on perception of sleepiness in working students is poor. Objective - Verifying patterns of sleepiness along the day and the possible impact of daily activities and life styles on sleepiness among working and non-working students. Methods The population studied comprised working and non-working high school students attending evening classes (19:00-22.30pm) at a public school in São Paulo, Brazil. The study group consisted of working and non-working students aged 14-21. The students selected filled in a questionnaire on living conditions, health and sleep, morningness-eveningness, characterization of working conditions, and frequency of food consumption. As a second step, records of their sleep-wake cycle were obtained through subjective methods (daily protocol of activities, sleep diary and sleepiness scale), as well as objective methods (Actigraphy). Socio-demographic, life style, work conditions and sleep-wake cycle variables were tested with the use of three-way ANOVA test (week day, time and work), Person's Qui-Square test $\left(\chi^{2}\right)$ and regression analysis. Results - 1) The average sleep duration for working students during weekdays was around 7 hours, whereas the sleep duration for nonworking students was around 9 hours; 2) working students' sleepiness patterns are different from those of non-working students. We found that working students were sleepier than non-working students in the first period (07:00am-09:00am) and in the last period recorded (10:00pm-12:00pm). We also found that working students were sleepier on specific days: on Mondays after lunch time (01:00pm03:00pm), on Wednesdays during classes (07:00pm-09:00pm) and on Fridays 
before bedtime (10:00pm-12:00pm). The highest level of sleepiness among students was found on Sundays, between 10:00pm-12:00pm. Also, at this time period working students in general were sleepier than non-working students, independently of the period and time of the day. 3) Other factors associated with sleepiness were: work, being a female, alcohol consumption, easiness of sleeping and going to bed after midnight. Conclusions - The sleepiness patterns for working students are different from those for non-working students, and the sleepwake cycle variables interfere in sleepiness levels during the day. In addition to chronobiological factors, there are other factors associated with changes in sleepiness levels: a) individual factors; b) social factors; c) socio-demographic factors; and d) life style. All these factors contribute to increase in working students' sleepiness at the beginning and end of the day; this may interfere in their school performance, impairing their physical and mental development, which is characteristic of adolescence. Intervention programs, such as those that provide information on sleep hygiene, and those related to social insertion, which would allow students to maintain and adequate life standard without having to be submitted to extended work journeys, should be implemented.

Descriptors: students, working students, sleepiness, sleep-wake cycle, chronobiology. 


\section{ÍNDICE}

1 INTRODUÇÃO

1.1 Adolescência

1.2 Juventude

1.3 Legislação referente ao trabalho de jovens

1.4 Trabalho infanto-juvenil

$1.5 \mathrm{O}$ estudo dos jovens

1.6 O lazer dos jovens

1.7 A prática esportiva dos jovens

1.8 A saúde dos jovens

1.9 Ciclo vigília-sono

1.10 Ciclo vigília-sono em jovens 40

1.11 Sono e trabalho 44

2 HIPÓTESES

3 OBJETIVOS

3.1 Objetivo geral

3.2 Objetivos específicos

4 METODOLOGIA

4.1 AMOSTRAGEM

4.1.1 Desenho do Estudo 
4.1.3 Perdas na Amostra $\quad 52$

4.2 SELEÇÃO DA ESCOLA

4.3 POPULAÇÃO

4.4 APRESENTAÇÃO DO PROJETO DE PESQUISA

4.5 CRITÉRIOS PARA SELEÇÃO DA POPULAÇÃO 54

4.6 TERMO DE CONSENTIMENTO (ANEXO 1)

4.7 INSTRUMENTOS DE PESQUISA

4.7.1 Questionário de Caracterização das Condições de Vida, Saúde e Sono (ANEXO

2) 56

4.7.2 Questionário de Identificação do Caráter de Matutinidade e Vespertinidade $\quad 58$

(ANEXO 3) 58

4.7.3 Questionário de Caracterização das Condições de Trabalho (ANEXO 4)

4.7.3.1 Escalas de Controle no Trabalho $\quad 59$

4.7.4 Questionário para consumo de cafeína, teobromina e bebidas alcoólicas (ANEXO 5)

4.7.4.1 Construção do Questionário de Freqüência de Consumo de Alimentos (QFCA) 61

4.7.5 Actímetro (ANEXO 6) 62

4.7.6 Protocolo Diário de Atividades e Diário de Sono (ANEXO 7) 65

4.7.7 Avaliação Subjetiva da Sonolência (ANEXO 8) 66

4.8 ETAPAS DE COLETAS DE DADOS 67

4.8.1 Coleta de Dados em 2002: primeira etapa 67

4.8.2 Coleta de Dados em 2002: segunda etapa 68 
4.8.3 Coleta de Dados em 2003: primeira etapa

4.8.4 Coleta de Dados em 2003: segunda etapa

4.8.5 Coleta de Dados em 2004: continuação da segunda etapa

5 RESULTADOS

5.1 Comparação da população matriculada no ensino médio no período de 2002 a 2003

e da população participante do estudo

5.2 Descrição da população estudada

5.3 Padrões de sono

5.4 Percepção da qualidade do sono, humor e facilidade para dormir e acordar

5.5 Padrões temporais da sonolência

5.6 Relação entre a sonolência diurna e as características do ciclo vigília-sono

5.7 Fatores independentes associados à sonolência

5.8 Súmula dos resultados

6 DISCUSSÃO

6.2 Consumo de álcool

6.3 Duração do sono

6.4 Regularidade

6.5 Eficiência do sono

6.6 Latência 
6.8 Cochilos

6.9 Qualidade do sono

6.10 Humor

6.11 Sonolência

6.12 Sonolência durante as aulas

6.13 Limitações do estudo

7 CONCLUSÕES

8 RECOMENDAÇÕES

9 REFERÊNCIAS BIBLIOGRÁFICAS

ANEXOS

ANEXO I - TERMO DE COMPROMISSO

ANEXO II - QUESTIONÁRIO DE CARACTERIZAÇÃO DAS CONDIÇÕES DE VIDA, SAÚDE E SONO DOS ADOLESCENTES

ANEXO III - QUESTIONÁRIO DE MATUTINIDADE - VESPERTINIDADE

ANEXO IV - QUESTIONÁRIO DE CARACTERIZAÇÃO DAS CONDIÇÕES DE TRABALHO

ANEXO V - QUESTIONÁRIO PARA CONSUMO DE CAFEÍNA, TEOBROMINA E BEBIDAS ALCOÓLICAS

ANEXO VII - DIÁRIO DE SONO E PROTOCOLO DE ESTUDANTES 
E TRABALHO E COVARIÁVEIS DO CICLO VIGÍLIA-SONO E DAS ESCALAS SUBJETIVAS

ANEXO X - TABELAS DE REGRESSÃO LOGÍSTICA DOS FATORES

ASSOCIADOS À SONOLÊNCIA 


\section{Lista de Quadros}

QUADRO 1 - Resumo da regressão logística para todos os dias da semana 


\section{Lista de Figuras}

Figura 1 - Padrão circadiano da propensão ao sono

Figura 2 - Esquema representativo do modelo de Borbély

Figura 3 - Fatores que contribuem para o aumento da sonolência em adolescentes

Figura 4 - Fatores que contribuem para o aumento da sonolência em jovens trabalhadores

Figura 5 - Possíveis inter-relações de variáveis independentes e dependentes, explicativas do sono e da sonolência diurna em jovens trabalhadores e nãotrabalhadores

Figura 6 - Actograma do ciclo vigília-sono de um estudante trabalhador do sexo masculino. São Paulo. 2001

Figura 7 - Actograma editado do ciclo vigília-sono de um estudante trabalhador do sexo masculino. São Paulo. 2001

Figura 8 - Média e erro-padrão da Escala de Sonolência Karolisnka, coletada a cada 3 horas por trabalhadores e não trabalhadores. Ensino Médio. São Paulo, SP.

Figura 9 - Sumula dos resultados 


\section{Lista de Tabelas}

Tabela 1 - Distribuição segundo série dos alunos matriculados na terceira série do Ensino Médio e das causas de perdas - Colégio Fernão Dias Paes - São Paulo - 2002.

Tabela 2 - Distribuição segundo série dos alunos matriculados no Ensino Médio e das causas de perdas - Colégio Fernão Dias Paes - São Paulo - 2003.

Tabela 3 - Descrição da população matriculada nos anos de 2002 e 2003 e da população estudada

Tabela 4 - Distribuição das características sócio-demográficas e estilos de vida. Estudantes trabalhadores e não-trabalhadores, estudantes do Ensino Médio.

Tabela 5 - Distribuição das variáveis relacionadas ao estudo. Estudantes trabalhadores e não-trabalhadores, estudantes do Ensino Médio.

Tabela 6 - Distribuição das variáveis relacionadas à saúde. Estudantes trabalhadores e não-trabalhadores, estudantes do Ensino Médio.

Tabela 7 - Distribuição das características de trabalho. Estudantes trabalhadores, estudantes do Ensino Médio.

Tabela 8 - Distribuição das variáveis relacionadas aos hábitos de sono. Estudantes trabalhadores, estudantes do Ensino Médio.

Tabela 9 - Média, erro-padrão e teste t-Student das características de sono. Estudantes trabalhadores e não-trabalhadores, Ensino Médio. São Paulo, SP.

Tabela 9 (cont.) - Média, erro-padrão e teste t-Student das características de sono. Estudantes trabalhadores e não-trabalhadores, Ensino Médio. São Paulo, SP.

Tabela 10 - Média, erro-padrão e test t-Student das escalas subjetivas, regularidade do sono e horário que sentiu sono.

Tabela 11 - Análise de variância com três fatores para as marcações a cada três horas da Escala de Sonolência Karolinska, durante uma semana.

Tabela 12 - Tabela-resumo com os resultados da ANOVA para dois fatores (dia e trabalho) e covariáveis relacionadas ao ciclo vigília-sono e escalas visuais analógicas.

Tabela 13 - Resumo da regressão logística dos fatores independentes associados à sonolência para todos os dias da semana. 


\section{INTRODUÇÃO}

\subsection{Adolescência}

A adolescência é caracterizada por uma série de transformações físicas, psicológicas e sociais. A faixa etária que abrange a adolescência varia segundo diferentes critérios, uns mais restritos e outros mais amplos (cronológico, de desenvolvimento físico, sociológico, psicológico, entre outros). $\mathrm{O}$ caráter histórico-social também é importante, pois mudam temporalmente e de sociedade para sociedade. Conseqüentemente, os papéis desempenhados e socialmente aceitos para a infância e adolescência têm sido distintos em tempos e em sociedades diferentes (CERVINI e BURGER, 1996).

Para a Organização Mundial de Saúde (OMS) são “considerados adolescentes todos aqueles que estão na faixa etária compreendida entre 10 e 20 anos" (OPAS, 1990). Contudo, a Lei no 8.069 de 13/07/90, que dispõe sobre o Estatuto da Criança e do Adolescente, em seu Artigo 2 do Título 1 - Das Disposições Preliminares, considera adolescente a pessoa entre 12 e 18 anos de idade.

Segundo NÉRICI (1969), na puberdade ocorre à maturidade biológica que deve ser entendida como o início da atividade de todas as glândulas de secreção interna que direta ou indiretamente provocam as mudanças anatômicas. Nas meninas as alterações biológicas se efetuam comumente entre os 10-13 anos, e são caracterizadas por: desenvolvimento das glândulas mamárias e dos órgãos sexuais internos e externos, maior desenvolvimento da cintura pélvica que a dos ombros, aumento da estatura, mudança no tom de voz, aparecimento de pêlos nas pernas, axilas e regiões genitais, pouco desenvolvimento muscular e tendência ao arredondamento das formas. Nos meninos as alterações biológicas se efetuam geralmente entre os 11-15 anos, e são caracterizadas por: aumento da estatura, maior desenvolvimento da cintura dos ombros do que da pélvica, desenvolvimento dos órgãos sexuais internos e externos, mudança no tom de voz 
mais acentuada do que na menina, aparecimento de pêlos na face, e grande desenvolvimento muscular, com tendência a angulosidade.

Em relação aos processos psicológicos, CHIPKEVITCH (1995), afirma ser a adolescência a fase da vida em que se consolida a identidade de gênero, que segundo o autor significa a representação que o indivíduo faz do seu próprio sexo, adquirida pela identificação com o genitor do mesmo sexo. Para este autor, o comportamento sexual do adolescente é, em grande parte, produto da sociedade e da cultura em que vive.

Numa definição sociológica, adolescência é uma etapa do desenvolvimento humano que se inicia na infância, caracterizando-se por profundas transformações físicas, emocionais e cognitivas (MINAYO-GOMES e MEIRELLES, 1997).

A adolescência não é um período de transição, é parte de um processo de amadurecimento e de intenso aprendizado de vida. A tendência de se limitar o adolescente a "um indivíduo em período de transição" tem favorecido o esquecimento de suas necessidades e a falta de respeito de seus direitos enquanto cidadão. $\mathrm{O}$ conjunto de modificações não apresenta início e término bem definidos e também não acontece ao mesmo tempo. Varia de indivíduo para indivíduo, de acordo com as características genético-hereditárias e das interferências do próprio meio em que cada um vive (MARCONDES e SETIAN, 1989).

Assim, o conjunto dessas relações vai delineando para o indivíduo uma identidade familiar, sexual e laboral, que lhe permite exercer um papel dentro da sociedade. Esta identidade é a imagem que o adolescente tem dele mesmo e dos vários papéis sociais que venha a desempenhar. Este processo é uma construção vivenciada e potencializada com o conjunto de condições de vida e sociais. Em circunstâncias desfavoráveis, o seu desenvolvimento biopsicossocial fica comprometido (MINAYO-GOMES e MEIRELLES, 1997).

\subsection{Juventude}


Segundo a Organização Mundial da Saúde, são considerados jovens os indivíduos dentro da faixa etária dos 15 e 24 anos de idade (BREINBAUER, 2005). É um período de intenso crescimento humano e maturação. Essa fase também é caracterizada pela baixa prevalência de doenças crônicas e infecciosas, e pelos altos riscos associados ao abuso de substâncias psicoativas, doenças sexualmente transmissíveis, violência. É uma fase na qual, muitos jovens adotam estilos de vida que mais tarde contribuirão para o desenvolvimento de doenças crônicas não-transmissíveis (obesidade, hipertensão, diabetes, doenças cardiovasculares, entre outras). Estas doenças vêm aumentando nos últimos anos, decorrentes das alterações dos padrões do consumo alimentar, inatividade física, tabagismo e consumo de bebidas alcoólicas (BREINBAUER, 2005).

Esta fase é parte de um processo de amadurecimento e intenso aprendizado de vida. Caso não seja bem sucedida, pode predispor ao início de problemas de ordem social, psicológica e física; entre eles depressão, sensação de solidão, pessimismo e sentimentos de baixa auto-estima. Estes problemas podem contribuir para que o jovem desenvolva pensamentos negativos sobre si próprio, assim como transtornos que afetarão seu bem-estar físico e mental (ROBERTS et al, 1998).

A partir deste momento o termo jovem será utilizado para descrever adolescentes e jovens.

\subsection{Legislação referente ao trabalho de jovens}

A definição de trabalho infantil pode variar segundo o autor. De acordo com SARTI (1999), trabalho infantil é aquele desenvolvido por pessoas até 14 anos de idade, e o trabalho do adolescente, de 15 a 18 anos, sendo ambos agregados na categoria de trabalho infanto-juvenil. Segundo a Organização Internacional do Trabalho (FORASTIERI, 1997), o termo "trabalho infantil" é definido de uma forma mais completa. Aqui reproduzimos este conceito (p.5)... “abrange todas as atividades econômicas desenvolvidas por pessoas com menos 
de 15 anos de idade, independente de seu status ocupacional (empregados, autônomos, trabalhadores que exercem suas atividades junto à família e não são remunerados). Ainda segundo este autor, o trabalho infantil não incluiria as atividades realizadas no âmbito doméstico pelas crianças e jovens nas suas residências, exceto onde o trabalho pode ser assimilado como uma atividade econômica, como por exemplo, crianças que ajudam no trabalho de seus pais e necessitam devotar tempo integral a este trabalho". Isto impediria as crianças de freqüentarem regularmente a escola. A OIT estipulou na "Convenção da Idade Mínima” para o Trabalho (número 138, de 1973), onde a criança deveria ter pelo menos de 12 ou 13 anos de idade. Entretanto, é recomendado que esta idade mínima seja maior (15 anos) e que o menor tenha completado a escolaridade obrigatória. Atividades perigosas, insalubres, e que atentam os princípios morais não devem ser realizadas por menores de 18 anos (ILO, 1995).

A legislação brasileira proíbe o trabalho noturno, perigoso e insalubre, a menores de 18 anos, e qualquer trabalho a menores de 16 anos, salvo na condição de aprendiz, a partir de 14 anos (Constituição Federal, 1988). até 1998, o trabalho era regulamentado para os adolescentes a partir de 12 anos. esta situação modificou-se com a publicação da emenda constitucional $n^{\circ}$. 20, de 15/12/98, que estipulou a idade mínima em 14 anos para aprendiz. Segundo Sarti (1999), à época da entrada em vigor desta emenda constitucional, havia quase 2 milhões de jovens em todo o país que estavam trabalhando. Questionava-se o que se poderia oferecer a esta imensa população de jovens que por lei deve deixar o trabalho.

Na condição de aprendiz, o trabalho dos jovens tem sido legitimado, mas freqüentemente prevalece o aspecto produtivo sobre o educativo, além de nem sempre haver condições apropriadas de saúde e segurança no trabalho (FISCHER et al, 2003b). Os aprendizes, usualmente, desconhecem seus direitos trabalhistas, submetendo-se a situações arriscadas, insalubres e inadequadas, a salários aviltantes, trabalhando horas-extras, não se protegendo adequadamente dos riscos e das péssimas condições de trabalho em geral. 
Para Robazzi et al (1996) muitas das leis presentes na constituição federal de 1988 não são cumpridas, particularmente quando se trata das crianças e jovens pertencentes às classes sociais menos favorecidas economicamente. Como os custos para pagar encargos trabalhistas são elevados, os empregadores são desestimulados a contratar trabalhadores de forma legal. Dessa forma, grande parte da população trabalhadora, particularmente a que executa trabalhos que são essenciais, mas mesmo assim são considerados menos nobres, é desqualificada, não registrada, alternando empregos temporários com fixos, dependendo da existência das necessidades regionais. Exemplos desta situação são os trabalhadores da construção civil, da coleta de lixo e empregados domésticos.

\subsection{Trabalho infanto-juvenil}

Segundo THOMPSON (1987), o capitalismo não inventou o trabalho infantil, mas criou as condições para que as crianças fossem transformadas em adultos precoces. Durante a Revolução Industrial, crianças e jovens eram forçadas a submeterem-se a longas jornadas de trabalho sem intervalo, recebendo um pagamento inferior ao do adulto pelo seu trabalho.

Segundo a Organização Internacional do Trabalho (OIT, 1996), calcula-se que atualmente duzentos milhões de crianças e jovens trabalhem em todo o mundo. Trata-se de uma mão-de-obra desorganizada, dócil e barata. Em 70\% dos casos, recebem, em média, meio salário-mínimo e, em muitos casos, cumprem jornadas de até 12 horas diárias de trabalho, principalmente os que atuam em ambientes altamente insalubres, como carvoarias, fábricas de sapato, canaviais e outras plantações.

Dados da Organização Internacional do Trabalho (OIT, 1996) indicam que o trabalho infantil está aumentando na África, na América Latina e, em menor ritmo, na Europa Central, na Oriental e nos Estados Unidos. Esses dados revelam que o trabalho infantil é mais freqüente na zona rural, do que na urbana. Estão as crianças e jovens mais ocupados em pequenas unidades de produção do setor urbano não estruturado, e do setor rural, como empregados em domicílios particulares, ou auxiliando na economia doméstica, com seus familiares. Os países 
pobres e aqueles com economias em transições de mercado, como as da Europa Oriental, usam maior percentual de mão de obra infantil e adolescente, do que os países desenvolvidos (FORASTIERI, 1997 e OIT, 1996). Considerando a faixa etária entre 5 e 14 anos, a Ásia tem cerca de $61 \%$ das crianças e adolescentes que trabalham, seguida pela África com $32 \%$, e América Latina com 7\%.

No Brasil, as mudanças que vêm ocorrendo na organização do trabalho desde os anos 70, entre elas a terciarização, têm provocado repercussões nas condições de vida e trabalho nos diferentes grupos da sociedade. Entre elas, destaca-se a situação do trabalho infanto-juvenil, que tem assumido proporções dramáticas e preocupantes, levando um grande contingente de menores a situações extremas de trabalho, as quais, além de interferir no seu processo de crescimento e desenvolvimento, colocam-nos vulneráveis à aquisição de doenças e, até mesmo, de seqüelas que acabam sendo irreversíveis para a sua vida adulta (MINAYOGOMES e MEIRELLES, 1997).

Segundo dados da PNAD de 2001 existem no Brasil cinco milhões e meio de crianças e adolescentes economicamente ativas entre 5 e 17 anos. A legislação vigente permite, sob proteção especial, o trabalho para maiores de 14 anos na condição de aprendiz e para maiores de 16 anos na condição de trabalhador. Entretanto, existem no Brasil cerca de 2 milhões de crianças e adolescentes entre 5 e 13 anos trabalhando. Sabe-se que também estão trabalhando 1 milhão e meio de adolescentes entre 14 e 15 anos e 2 milhões com 16 a 17 anos (IBGE, 2003). Entre estes, pouquíssimos poderiam ser incluídos na condição de aprendiz ou estão em situação de proteção especial. Segundo a Organização Internacional do Trabalho (ILO, 2002) aproximadamente metade destes adolescentes trabalhadores estão inseridos em atividades perigosas.

Embora tenha havido uma redução de 34,9\% no número de trabalhadores precoces entre 1992 e 2001, o número de crianças trabalhando ainda é expressivo. Assim, o estabelecimento de políticas para a erradicação do trabalho infantil poderia intensificar esta tendência de redução. Entre os trabalhadores precoces $65,1 \%$ são homens, $33,5 \%$ trabalham 40 horas ou mais por semana, $48,6 \%$ não 
tem remuneração, mais da metade utiliza produtos químicos, máquinas, ferramentas ou instrumentos no trabalho e $80 \%$ combina o trabalho com a freqüência à escola. A maior parte trabalha em atividade agrícola $(43,4 \%)$, porém este percentual é mais elevado nas faixas etárias mais jovens alcançando 75,9\% no grupo de 5 a 9 anos e 56\% no grupo de 10 a 14 anos (IBGE, 2003). Sabe-se também que mais de $80 \%$ dos trabalhadores precoces estão inseridos no setor informal da economia e que os serviços domésticos são provavelmente uma das atividades urbanas que mais emprega trabalhadores precoces (FACCHINI et al, 2003). Essa forma oculta de trabalho infantil em casa de terceiros ou em sua própria casa, e sem oportunidade de estudar ou brincar compõem um exército invisível de mão-de-obra, que está sujeita a toda sorte de exploração.

Na região Metropolitana de São Paulo, 5,9\% das crianças e adolescentes entre 10 e 17 anos de idade trabalhavam e 22\% estavam desempregados (SEADE, 1996). Dados da PNAD de 2003 mostram que, no Brasil, entre os adolescentes de 15 a 17 anos de idade, $10,3 \%$ só trabalham, 22,8\% trabalham e estudam, $55.7 \%$ só estudam e 2,6\% não realizam nenhuma atividade. Esses números se diferem de acordo com a região do Brasil. A região sudeste foi a que apresentou a maior porcentagem de adolescentes que apenas estudam (61,6\%), seguida da região norte $(61,4 \%)$, região centro-oeste $(53,7 \%)$, região nordeste $(50,5 \%)$ e região sul $(48,9 \%)$. Entre os adolescentes que apenas trabalham, pôde-se verificar que a região sul foi a que apresentou maior número de adolescentes trabalhadores $(13,7 \%)$, seguida da região nordeste $(11,6 \%)$, região centro-oeste $(10,9 \%)$, região sudeste $(8,5 \%)$ e região norte $(8 \%)$. Da mesma forma apresentou-se o número de adolescentes que trabalham e estudam. A região sul e nordeste mostram que $26,2 \%$ de adolescentes exercem ambas as atividades, seguida da região centrooeste $(24,1 \%)$, região sudeste $(19,3 \%)$ e região norte $(19 \%)$.

Vieira (2001) mostrou a grande importância dos jovens na formação da população economicamente ativa no Brasil. Segundo a autora, os jovens entre 15 e 24 representam uma fração significativa da mão-de-obra brasileira, representando, 63\% da PEA no Brasil. Entretanto, possuem uma posição frágil no mercado de trabalho. São geralmente encontrados no mercado informal, onde são 
mal remunerados e desprotegidos por lei, além das precárias condições de trabalho. $\mathrm{O}$ autor constatou que a média de horas trabalhadas pelos jovens não é muito diferente da média encontrada para os adultos (43 horas semanais) e que as funções são semelhantes. Entretanto, o rendimento é inferior, sendo em média $40 \%$ inferior ao rendimento dos adultos (jovens de 15 a 19 anos). Geralmente, esses jovens estão inseridos no mercado de trabalho informal, decorrente da grande desigualdade na distribuição de renda no país, sendo o seu rendimento significativo na composição da renda familiar.

Conseqüentemente, o grande número de crianças e jovens no mercado formal e informal reflete o empobrecimento do país, já que, quanto maior o desemprego, maior o número de trabalhadores adultos e jovens ocupados em subempregos, para poderem, juntos, formar uma renda que permita a subsistência da família. Portanto, a pobreza aparece como principal elemento explicativo para o trabalho precoce de crianças e jovens, na medida em que a saída de crianças e jovens rumo ao mercado de trabalho é produto de uma decisão familiar, na qual os adultos têm um peso maior. Dados do PNAD (IBGE, 2003) demonstram que nas famílias maiores, com 7 componentes ou mais, cerca de $20 \%$ das crianças e adolescentes trabalhavam. Em relação ao rendimento mensal das famílias a que pertenciam, 18,9\% das crianças e adolescentes que trabalhavam tinham renda familiar mensal na faixa de até $1 / 2$ salário mínimo, reduzindo-se a 7,5\% na faixa de 10 salários mínimos ou mais (SCHILL et al, 1985).

De forma geral, o trabalho do menor é culturalmente aceito pelas famílias, tanto das classes populares, quanto para as mais favorecidas economicamente. A pobreza é um dos fatores que explicam a aceitação do trabalho infantil. As famílias oferecem a mão-de-obra dos filhos menores de idade, justificando ser melhor para a criança e o jovem estar trabalhando do que permanecendo nas ruas, expostos ao crime, marginalidade, dependendo de esmolas e submetendo-se a riscos e atividades laborativas violentas, tal como a prostituição (ROBAZZI et al, 1996). 
Muitos são aqueles que argumentam sobre os aspectos positivos e benéficos da entrada na força de trabalho precocemente. Será positivo se contribuir para o crescimento como pessoa ou cidadão, incorporando sentimentos de auto-estima e realização à sua personalidade, desde que compatível e equilibrado com seu potencial energético (FORASTIERI, 1997). São também citados como favoráveis o desenvolvimento do senso de responsabilidade, a aquisição de novas qualificações, as oportunidades de iniciar-se em carreiras, o avanço econômico. Essas concepções se apresentam hoje através de expressões como "ocupar o seu tempo", "tirá-lo da rua", "tirá-lo da marginalidade", "aprender uma profissão", "ajudar a família" (DUNN et al, 1998).

MARX (1996) no século XVIII já relatava acordos feitos entre capitalistas e famílias de baixa renda, para o aluguel de crianças. Por meio desses acordos as crianças eram exploradas com a justificativa do aprendizado de um ofício e das dificuldades financeiras da família. Além disso, os familiares consideravam os empresários benfeitores da família e das próprias crianças. Tais idéias são empregadas atualmente e chegam a ser institucionalizadas, através da criação de programas educativos, sob a justificativa de promover políticas sociais redistributivas, que tendem a atuar numa perspectiva meramente profissionalizante, constituindo-se em instrumentos de legitimação para a manutenção e reprodução social da pobreza e da estrutura ocupacional (MINAYO-GOMES e MEIRELLES, 1997).

A partir dos anos 90, esses programas tiveram um maior impulso, agindo como alternativas educacionais para crianças e jovens que elegem a rua como espaço de sobrevivência e de resistência social Entretanto, ao invés de essas ações contribuírem para a criação de cidadãos, acabam reforçando toda uma situação de exclusão social, por não apresentarem uma proposta pedagógica mais ampla que incorpore questões nas áreas de saúde, educação, cultura, lazer, trabalho, entre outras (MINAYO-GOMES e MEIRELLES, 1997).

Devido ao fato do trabalho infanto-juvenil ser usualmente mais barato que o pagamento a adultos trabalhadores, quanto maior o número de crianças e jovens 
integrados à força de trabalho, menores serão os salários dos adultos, menores serão os incentivos a mudanças tecnológicas para melhorar a segurança e conforto no trabalho (RICHTER e JACOBS, 1991). Segundo estes autores, há situações que se assemelham entre os países onde há grande número de menores trabalhando: é baixo o produto nacional bruto per capita, e igualmente baixo o índice de escolaridade no nível médio. Desta forma, encontram-se disponíveis um numeroso grupo de jovens sem educação e treinamento adequados que se submetem a difíceis, perigosas e extenuantes jornadas de trabalho, mesmo recebendo baixo pagamento.

Para CAMPOS e FRANCISCHINI (2003) os fatores citados acima, (aumento da mão-de-obra infantil e o aumento do desemprego dos adultos), podem ser responsáveis pela reorganização na estrutura familiar, alterando funções e o status de seus membros. O jovem aparece como membro de maior status. É ele que tem o melhor emprego e renda podendo sustentar a família e, devido a esses motivos, ter maior liberdade. Essas mudanças na estrutura familiar podem representar para o jovem uma inserção artificial na vida adulta. Nessas condições, independência financeira pode ser percebida como independência emocional e social por um indivíduo que ainda está se desenvolvendo. Nesta etapa da vida o jovem necessita de orientação, pois não tem maturidade física, cognitiva, emocional ou social para o exercício das funções por ele assumidas. Além disso, os jovens trabalhadores passam a desvalorizar o ensino e os professores. Para eles, os professores, apesar do tempo dedicado a formação profissional, não são remunerados adequadamente, ao contrário de alguns indivíduos com baixa escolaridade, mas que possuem bons salários.

Em publicação dedicada ao trabalho infantil e do adolescente, do National Institute for Occupational Health dos Estados Unidos (NIOSH, 1997) são descritos os riscos de natureza física, fisiológica e psicossocial que atingem os trabalhadores. Os fatores de natureza física e fisiológica compreendem, principalmente, às dimensões antropométricas (tamanho, crescimento) e ainda, necessidades de sono, susceptibilidade a acidentes e doenças, exposição a agentes físicos e químicos. Os chamados riscos psicossociais envolvem exposição a 
situações e agravos incompatíveis com o estágio de maturação emocional, que pode estar obscurecida pela maturação física do adolescente. Assim, o adolescente pode estar exposto a tarefas para as quais não está preparado, tanto pelos aspectos físicos, quanto emocionais e cognitivos. Também fazem parte da lista de agravos à saúde, entre outros, a falta de experiência no trabalho, de adequada supervisão, da necessidade para executar tarefas perigosas, da falta de conhecimento sobre os riscos do trabalho. Também são fatores importantes, os débitos acumulados de sono decorrentes das atividades de trabalho e estudo. A perda aguda de sono (por exemplo, privação de sono por uma noite) gera nível elevado de sonolência durante o dia, momentos de desatenção, curtos episódios de sono que passam despercebidos, queda no desempenho e alterações dos estados de ânimo.

Situações de trabalho impróprias à saúde e ao desenvolvimento físico da criança e do jovem podem causar efeito imediato, a médio ou longo prazo. Podem acarretar perda de visão e audição, mutilação de membros, desvios na estrutura corporal, atrofia do crescimento. Algumas dessas lesões ou doenças podem levar anos para serem diagnosticadas (ASMUS et al, 1996).

\section{$1.5 \mathrm{O}$ estudo dos jovens}

Uma das conseqüências mais sérias e comuns do trabalho infantil, pelo tempo que absorve e pela exaustão que provoca, é impedir o desenvolvimento intelectual da criança (ASMUS et al, 1996).

O trabalho precoce, geralmente, promove efeitos negativos no desenvolvimento físico e educacional, impedindo o jovem de dedicar-se a atividades extracurriculares, tais como, atividades lúdicas e sociais próprias da idade, trazendo isolamento dos jovens entre seus pares e familiares, bem como pode ser responsável pelo atraso escolar (OLIVEIRA et al, 2001). Neste estudo verificaram que os alunos que referem chegar atrasados devido ao trabalho têm 10 vezes a chance de vir a sofrer retenção escolar; aqueles que referem ter dificuldade de concentração nos estudos têm 1,8 vezes a chance de sofrer retenção escolar; para os que têm 2 ou mais empregos essa probabilidade é de 
aproximadamente 2,5 vezes; começar a trabalhar antes dos 11 anos aumenta 1,5 vezes o risco de retenção escolar. A retenção escolar é uma das principais razões que levam à evasão escolar, e o futuro tão almejado através do trabalho resultará num profissional desqualificado e sem possibilidades de competir num mercado de trabalho cada vez mais especializado e complexo.

Para pais e educadores, reprovação e desistência dos estudantes trabalhadores são explicadas como decorrentes de brincadeiras, desatenção e falta de interesse. Pais e educadores não conseguem entender que, o tempo gasto na escola representa o único momento em que é possível aos trabalhadores encontrar os colegas, conversar, brincar, etc., isto é, ser jovem. Para o estudante, a atividade laborativa transforma-se freqüentemente em fonte de estresse, ao contrapor-se a seu processo de diferenciação e maturação. O jovem precisa de tempo, espaço e condições favoráveis para realizar sua transição em direção à vida adulta. Assim, o trabalho acaba impondo a esses jovens um conjunto de situações desfavoráveis, contrapondo-se ao seu momento de descoberta individual (CAMPOS e FRANCISCHINI, 2003).

Dados do PNAD (IBGE, 2003) demonstram que cerca de um terço da população ocupada entre 5 e 17 anos de idade trabalhavam habitualmente 40 horas ou mais por semana. Destes, $65,2 \%$ não freqüentavam a escola e $25,7 \%$ freqüentavam. Considerando a desagregação por faixa etária, constataram-se diferenças marcantes. Entre os estudantes que cumpriam jornada de trabalho de 40 horas ou mais por semana, 9,8\% tinham entre 10 a 14 anos de idade e 40,2\% entre 15 a 17 anos de idade.

As jornadas de trabalho dos jovens são usualmente de 8 horas diárias, o que restringe ou torna difícil conciliar o trabalho com o estudo, restando aos jovens a alternativa de cursarem a escola noturna, que na grande maioria das vezes limita as possibilidades de continuidade do processo de escolarização. Em estudo realizado pelo PNAD (IBGE, 2003) verificou-se que os estudantes (entre 5 e 17 anos de idade) que permaneciam mais de quatro horas diárias na escola 
realizando atividades curriculares e extracurriculares representavam 41,5\% dos estudantes.

Mesmo não sendo a jornada de trabalho coincidente com o horário escolar, os estudos fora deste horário ficam prejudicados afetando o rendimento escolar. Estudos conduzidos por ANDRADE (1997), CARSKADON et al (1989) e CARSKADON (1990) mostraram que o sono dos adolescentes fica prejudicado devido aos horários de entrada na escola, e à fadiga causada pelo trabalho, além de aumentar os riscos de acidentes decorrentes da sonolência durante o trabalho.

O DIEESE (1996) divulgou os dados sobre uma pesquisa realizada com estudantes trabalhadores de seis capitais brasileiras (Belém, Recife, Goiânia, Belo Horizonte, São Paulo e Porto Alegre), no período de 1995 e 1996. Foram entrevistados 1419 estudantes de até 15 anos de idade. Desses, em torno de 20\% trabalhavam em atividades desenvolvidas na rua; mais de $60 \%$ trabalhavam 4 horas ou mais por dia. Em relação aos que trabalhavam, o índice de repetência nas escolas, Belo Horizonte possuía o menor percentual (51\%), São Paulo, Porto Alegre e Goiânia tinham índices acima de 60\% e em Belém e Recife o percentual dos entrevistados ultrapassou os $70 \%$. Essas prevalências são superiores a encontrada por todos os estudantes entrevistados (em torno de 20\%).

Anualmente o Ministério da Educação realiza o Exame Nacional do Ensino Médio - ENEM, para avaliar o rendimento escolar de todos os estudantes do Ensino Média. Durante o exame, os estudantes respondem a questionários e alguns estudantes participam de grupos-focais. No relatório de 2004, o Ministério da Educação verificou que mais da metade dos participantes trabalharam ganhando algum salário ou rendimento. Destes, $38 \%$ trabalharam durante todo o tempo em que estudaram durante o ensino médio. Em âmbito nacional, 37\% dos jovens entrevistados acreditam que trabalhar prejudica os estudos e 13,3\% dos estudantes já abandonaram a escola pelo menos uma vez devido ao trabalho.

As atividades de trabalho desenvolvidas precocemente por menores são fatores decisivos em suas vidas, podendo ter conseqüências (negativas e ou positivas) ao seu completo desenvolvimento. Para os jovens de classes sociais 
com maior renda, o trabalho está ligado à maturidade e a emancipação econômica (MIELNIK, 1987). Para esses estudantes, trabalhar ou não é uma escolha que não prejudica sua vida escolar.

Outros autores ao analisarem o efeito do trabalho sobre o rendimento escolar encontraram resultados contraditórios. D’AMICO (1984) e MORTIMER et al (1996) verificaram que adolescentes trabalhadores com jornada de trabalho inferior a $20 \mathrm{hs} / \mathrm{semanais} \mathrm{e} \mathrm{atividades} \mathrm{com} \mathrm{baixa} \mathrm{intensidade} \mathrm{faltam} \mathrm{menos} \mathrm{às}$ aulas e possuem melhor rendimento escolar, demonstrando a idéia de que o trabalho promove comportamento positivo.

Para jovens de classes sociais com menor renda, o trabalho é necessário e, portanto, a legislação que proíbe o trabalho antes dos 16 anos impede o acesso desses jovens a uma renda importante para eles e para a família (MINISTÉRIO DA EDUCAÇÃO, 2004).

Nas regiões Norte e Nordeste os estudantes relatam que o trabalho prejudica o desempenho escolar, mas é responsável pelo amadurecimento e responsabilidade, prevenindo da delinqüência social. Para esses participantes, o trabalho de jovens deve ter jornada diária e semanal reduzida e com características de formação profissional (MINISTÉRIO DA EDUCAÇÃO, 2004).

Em estudo de coorte que está sendo conduzido por SANTANA et al (2005) foi verificado que os estudantes do sexo masculino relatam estarem insatisfeitos com a escola e faltam mais às aulas quando comparados com as meninas. Em relação ao atraso escolar, as meninas chegam mais atrasadas às aulas quando comparadas com os meninos, mas devido à flexibilidade no horário de trabalho (trabalho doméstico informal) há maior facilidade para preparar a lição de casa e ir à escola.

Alguns autores apontam a relação entre a sonolência diurna em jovens adultos e problemas de atenção, baixo nível de desempenho acadêmico e maior incidência de uso de substâncias estimulantes (GIANNOTTI et al, 2002; LACK, 1986; THORPY et al, 1988). Segundo DINGES e KRIBBS (1991), a privação de 
sono está relacionada ao débito de memória, ao desempenho escolar reduzido, à sonolência diurna, falta às aulas, e ocorre uma diminuição no tempo utilizado para realizar as tarefas escolares provavelmente em decorrência do cansaço. Pode-se supor que o prejuízo no desempenho escolar causado pela privação de sono seria conseqüência da menor capacidade de atenção e concentração do aluno nas diferentes atividades escolares. Evidências fornecidas pelo estudo em laboratório feito por RANDAZZO et al (1998) mostraram que uma única noite de restrição de sono (5 horas de sono ou $50 \%$ da duração de sono diária) prejudicava funções cognitivas de crianças de 10 a 14 anos de idade.

Outros estudos (STICKGOLD et al, 2000; WALKER et al, 2002) demonstraram que o aprendizado de habilidades sensório-motoras, como por exemplo, esportes, tocar instrumentos musicais, ou desenvolver movimentos artísticos controlados, necessitam de uma "completa noite de sono" para uma ótima consolidação do aprendizado.

LOUZADA (2003) realizou um estudo comparativo das características do ciclo vigília-sono de adolescentes que vivem em diferentes ambientes sócioculturais (uma população urbana, e duas populações que vivem na zona rural do interior do Estado de São Paulo). Participaram do estudo 612 adolescentes, que responderam um questionário sobre hábitos de sono. Este estudo demonstrou que adolescentes que vivem no ambiente urbano tendem a apresentar as fases do ciclo vigília-sono atrasadas quando comparadas àquelas de adolescentes que vivem em áreas rurais. Também os alunos submetidos ao turno matutino apresentam uma redução na duração de sono e aumento da sonolência percebida durante as aulas quando comparados aos alunos do turno vespertino. Portanto, nas populações estudadas, o contexto sócio-cultural influencia a expressão do ciclo vigília-sono em adolescentes. Os horários escolares atuam como potentes sincronizadores ${ }^{1}$ e/ou mascaradores ${ }^{2}$ do ciclo vigília-sono em adolescentes.

\footnotetext{
${ }^{1}$ Estímulos ambientais que promovem o ajuste de um ritmo a um ciclo ambiental, como, por exemplo, o ajuste do ciclo atividade/repouso ao claro/escuro ambiental (MARQUES e MENNABARRETO, 1997).

2 Agente que promove a modificação da expressão de um ritmo biológico (MARQUES e MENNA-BARRETO, 1997).
} 


\subsection{O lazer dos jovens}

Segundo estudo de FITZGERALD e LAIDLAW (1995) e MINISTÉRIO DA EDUCAÇÃO (2004), ir à casa dos amigos é o principal entretenimento dos jovens, citado por $53 \%$ dos entrevistados. Assistir televisão vem logo a seguir (51\%), como a segunda principal fonte de diversão e lazer e passear pela rua e praticar esportes em terceiro lugar (ambos com 47\%). Em estudo realizado por MATSUDO et al (1997) no Brasil o tempo médio dedicado diariamente pelos jovens a assistir televisão é $3 \mathrm{~h} 55 \mathrm{~min}$, sendo em média $4 \mathrm{~h}$ para adolescentes entre 12 e 14 anos e $3 \mathrm{~h} 49$ min para adolescentes entre 15 e 17 anos.

Segundo FITZGERALD e LAIDLAW (1995) assistir televisão oferece a segurança nem sempre encontrada nas ruas das grandes cidades onde os jovens poderiam praticar atividades físicas, principalmente o futebol. Os ambientes inseguros nas cidades são uma das barreiras à prática regular de atividades físicas (SALLIS e OWEN, 1999). Além da televisão, 45\% dos jovens escutam música diariamente, $59 \%$ lêem jornais e revistas esporadicamente. O tipo de leitura preferido pelos jovens são jornais diários e revistas informativas (MINISTÉRIO DA EDUCAÇÃO, 2004).

Para o MINISTÉRIO DA EDUCAÇÃO (2004) as atividades básicas de lazer parecem dividir-se entre aquelas realizadas nas escolas (projetos de oficinas oferecidos à comunidade e utilização da estrutura de esporte) ou 'na rua' (esportes, conversa com amigos); e os eventos pagos ou privados, como shoppings, cinemas e boates, acessar a Internet e ouvir música em casa. Para adolescentes de 15 a 17 anos, se houvesse projetos de lazer específicos para jovens, com espaços adequados e boa estrutura, o índice de violência diminuiria.

\subsection{A prática esportiva dos jovens}

Três são os mundos básicos dos jovens: amigos, casa e escola. A ocorrência de um quarto mundo, correspondente ao trabalho, pode interferir no desenvolvimento dos jovens. 
O restante do tempo que sobra para o jovem trabalhador é empregado na escola noturna, no descanso diário e com os amigos. "Dedicando $25 \%$ de seu tempo semanal ao trabalho e $12 \%$ à escola, os jovens identificam-se mais com a classe trabalhadora do que como educando e é desse mesmo modo que são reconhecidos pela própria família. Eles sofrem pressão da família para não perderem o emprego, da escola para passarem de ano e, do empregador, exigindo maior produtividade" (FITZGERALD e LAIDLAW, 1995).

O trabalho além de prejudicar o sono também diminui o tempo disponível para o lazer, vida em família, educação, e oportunidade de estabelecer relações de convivência com seus pares, privando o jovem trabalhador de um desenvolvimento saudável (MINAYO-GOMEZ e MEIRELLES, 2001).

FISCHER et al (2003a) relatam que trabalhar 20 horas ou mais por semana pode interferir no desempenho escolar devido à fadiga e ao tempo insuficiente para os estudos, além de contribuir para o consumo de bebidas alcoólicas e cafeína, o tabagismo e interferir na participação de atividades extracurriculares e familiares.

Os trabalhos de MECHANIC e HANSELL, 1987; NUTBEAM et al, 1989; e SILVA e MALINA (2000), com adolescentes brasileiros revelaram que, apesar dos baixos níveis de atividade física em ambos os sexos, os adolescentes apresentam maior nível de atividade física nos fins-de-semana em comparação aos dias da semana. SAITO e SILVA (2001) comentam que este fato pode determinar maiores riscos de lesões pela falta de condicionamento físico adequado e pela, em geral, maior intensidade e duração com que são praticados nessas ocasiões.

SILVA e MALINA (2000) também concluíram que 85\% dos meninos e 94\% das meninas podem ser classificados como sedentários, demonstrando que os homens tendem a ser mais ativos do que as mulheres. A prática do futebol, esporte que faz parte da cultura nacional é um fator determinante para essa diferença. Entre as meninas, a dança é a principal atividade física realizada. Já a duração das atividades físicas foi em média de $1 \mathrm{~h} 30 \mathrm{~min} /$ dia para os adolescentes trabalhadores durante os fins-de-semana o que pode estar relacionado ao maior tempo livre 
nestes dias, o que possibilitaria a utilização desse período com atividades lúdicas e esportivas.

Segundo GREYDANUS et al (2004) a prática da atividade física regular promove o desenvolvimento físico (força, flexibilidade e resistência), a coordenação motora, e as habilidades mentais. Também melhora a saúde, previne doenças, a obesidade e o uso e/ou abuso do fumo e de outras drogas lícitas e ilícitas. Além desses fatores, as atividades físicas são importantes agentes no desenvolvimento da personalidade, principalmente a personalidade social, devido ao aprendizado das relações humanas: solidariedade, trabalho em equipe, senso de responsabilidade, disciplina, cidadania, competitividade, auto-estima, etc., que são fundamentais para a vida profissional (ILO, 1975).

\subsection{A saúde dos jovens}

VICTORA et al (2003) está realizando um estudo de coorte iniciado em 1982. Este é o primeiro estudo longitudinal realizado com adolescentes no Brasil. Seus resultados demonstram os principais fatores de risco para doenças crônicas entre adolescentes de baixa e alta classe social. Entre adolescentes que nasceram em famílias de baixa renda, fumar diariamente e irregularidade na prática de atividade física durante o tempo livre são os principais fatores de risco. Já para os adolescentes que nasceram em famílias ricas, sobrepeso, obesidade, dieta rica em gorduras, maior colesterol total e maior ingestão de álcool durante a semana são os principais fatores de risco. A autora não analisa o efeito do trabalho na saúde, mas alguns autores (FISCHER et al, 2005; MORTIMER et al, 1996) analisaram o efeito do trabalho na auto-percepção da saúde.

O estudo de coorte de MORTIMER et al (1996), verificaram que a baixa auto-estima e depressão estão associados com auto-percepção da saúde. E, que, a auto-percepção da saúde está associada com estresse no trabalho. FISCHER et al (2005) ao analisarem questionários respondidos por 354 adolescentes entre 14-18 anos de idade, verificaram que o controle no trabalho tem efeitos negativos sobre a saúde dos adolescentes trabalhadores. Seus resultados demonstram que há correlação entre auto-percepção de insegurança no trabalho com redução da 
duração do sono e aumento da jornada de trabalho. Além disso, exigências psicológicas do trabalho estão associadas com queixas de saúde, relatos de dores no corpo, acidentes de trabalho e menor duração do sono nos dias da semana. Esses resultados ilustram as duas escolhas que os adolescentes têm: eles podem se dedicar ao trabalho ou à escola, pois quanto maior a jornada de trabalho, mais seguro os adolescentes se sentem em seus empregos, mas, por outro lado, reduzem a duração de sono.

Entretanto, para muitos autores (FASSA, 2003; MORTIMER et al, 1996; FITZGERALD e LAIDLAW, 1995) o trabalho na adolescência tem efeitos positivos no desenvolvimento psicológico e na saúde mental. Esses resultados positivos precisam ser olhados com cuidado, pois o "Efeito do Trabalhador Sadio" não pode ser esquecido.

\subsection{Ciclo vigília-sono}

O ciclo vigília-sono ${ }^{3}$ é um ritmo biológico em que sua expressão não é rígida, pois tende a se alterar de acordo com as informações provenientes do meio interno e externo. As imposições sociais são importantes fatores que podem conduzir a modificações dramáticas nos padrões de sono. De fato, a estrutura e a duração do sono são influenciadas por fatores internos e externos, como os sócioculturais (LOUZADA e MENNA-BARRETO, 2003), ambientais (CARSKADON et al, 1980), fisiológicos e psicológicos. Além desses fatores, outros fatores, como por exemplo, humor, classe social, ambiente familiar, e diferenças sazonais, climáticas e geográficas podem interferir no ciclo vigília-sono (HARRISON e HORNE, 1995; TERMAN e HOCKING, 1913).

Afirmar que o ciclo vigília-sono é um ritmo flexível não significa dizer que as alterações possam ocorrer em qualquer sentido e desprovidas de conseqüências. Mesmo que a pessoa não adormeça, ela apresenta um aumento da propensão ao sono em certos momentos do dia (LAVIE e SCHERSON, 1981). Portanto, existem momentos do dia, como no final da tarde, propícios à ocorrência 
da vigília denominados zonas de manutenção da vigília, nos quais as pessoas dificilmente conseguem adormecer (STROGATZ, 1986). Também existem momentos durante o dia, onde há maior facilidade para iniciar o sono, como no início do sono noturno e do cochilo da tarde, quando também ocorrem os menores valores da temperatura corporal (STROGATZ, 1986).

Para explicar as flutuações do ciclo vigília-sono foram criados modelos de sono. O primeiro modelo de regulação de sono - Processo " $S$ " de WEBB e AGNEW (1971), considerava apenas a necessidade de sono como determinante do início do sono (Figura 1). Mais tarde, as variações de latência e duração do sono ao longo das 24 horas passaram a ser consideradas como fatores de determinação do início do sono (CARSKADON e DEMENT, 1975). Atualmente, um dos modelos mais aceitos é o modelo de BORBÉLY (1982) onde o início do sono seria determinado pela interação entre o momento circadiano para adormecer (Processo C) e o aumento da necessidade de sono (Processo S), controlados pelos relógios biológicos (Figura 2). Com o decorrer do sono, a necessidade de sono diminuiria coincidindo com a tendência circadiana para acordar. Em 1988, a este modelo foi acrescentado o fator "respostas comportamentais" como um terceiro fator de regulação do ciclo vigília-sono (WEBB, 1988).

Atualmente, propriedades anatômicas, celulares, e moleculares dos relógios biológicos têm sido estudadas. Hipóteses a respeito dos processos neuroquímicos ou neurocelulares, como os osciladores tálamocorticais (STERIADE et al, 1993), e mudanças na expressão do gene dos relógios biológicos têm sido descritas (CIRELLI, 2002).

\footnotetext{
${ }^{3}$ Ciclo vigília-sono: São as relações temporais da fase de sono e vigília em relação ao tempo convencional do relógio, no ciclo de 24 horas (MARQUES e MENNA-BARRETO, 1997).
} 
Figura 1. Padrão circadiano da propensão ao sono.

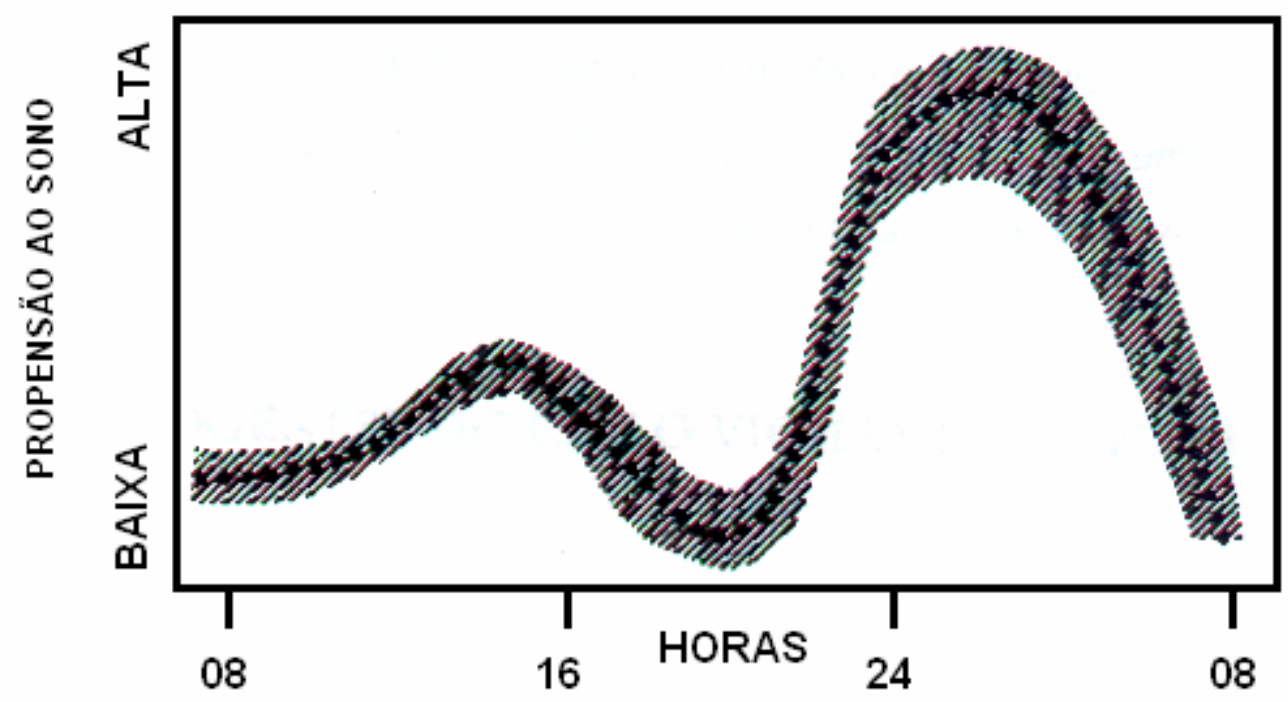

Fonte: LAVIE, 1996.

Figura 2. Esquema representativo do modelo de Borbély.

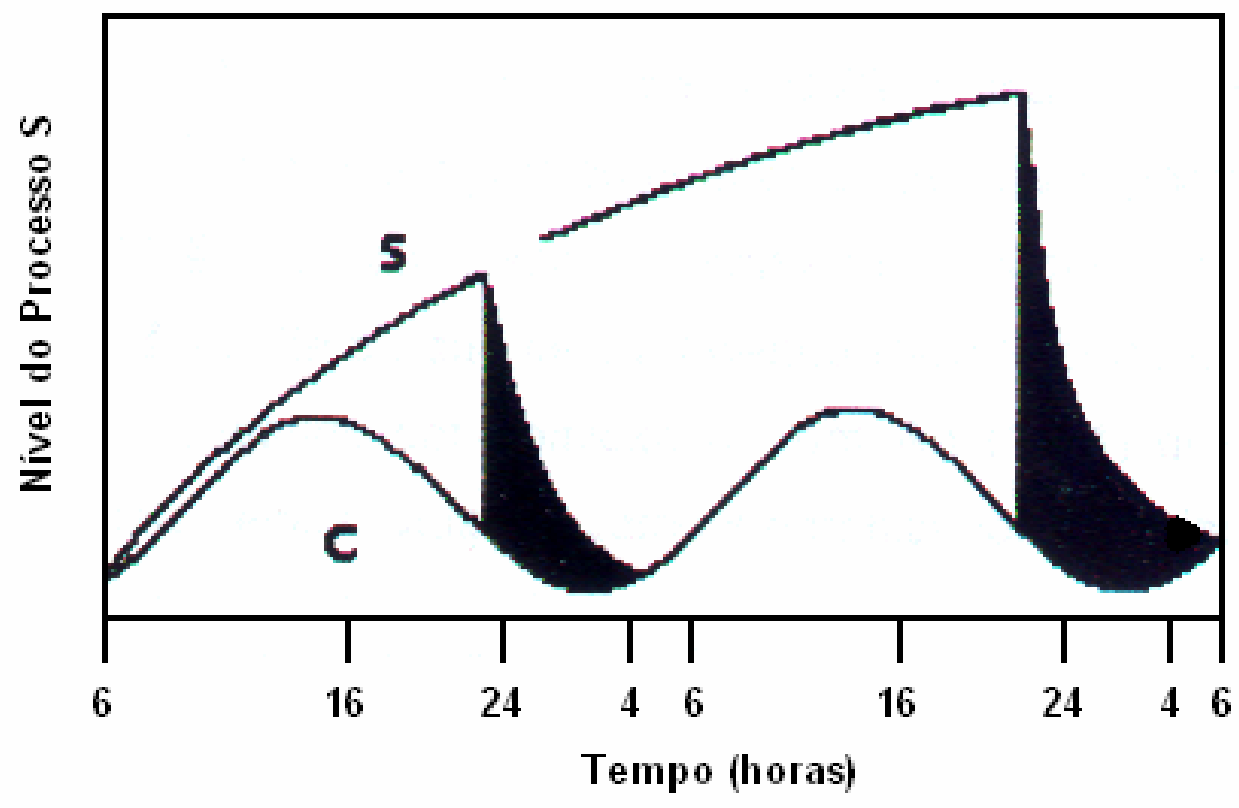

Fonte: MARQUES e MENNA-BARRETO, 1997. O sono ocorre durante a área hachurada, acabando quando S cai abaixo de C. A evolução do processo S é mostrada durante o sono após uma vigília (à esquerda) e durante o sono após uma vigília prolongada (à direita). 
O padrão do ciclo vigília-sono depende ainda de características individuais, como a idade, gênero, trabalho, tipo cronobiológico (matutino, vespertino ou indiferente), capacidade para tolerar a sonolência, necessidade do sono (pequenos e grandes dormidores), predisposição para os cochilos (cochiladores e os não-cochiladores), número e duração dos cochilos e fatores genéticos (VAN DONGEN e DINGES, 2000).

Quanto à duração do sono, os indivíduos são classificados em grandes, médios e pequenos dormidores de acordo com a necessidade de sono nas 24 horas. Os indivíduos adultos pequenos dormidores necessitam de 6 horas ou menos por dia, os médios dormidores entre 6 e 9 horas de sono, e os grandes dormidores necessitam de 9 horas ou mais de sono (WEBB, 1979). Alguns estudos mostram que nestes três tipos de dormidores há distribuição diferente das diversas fases do sono ao longo da noite (WEBB e AGNEW, 1970) e o pico do alerta ocorre em momentos distintos do dia (BENOIT et al, 1981). BENOIT et al (1981) também relatam que os grandes e pequenos dormidores reagem de forma diferente à privação de uma mesma quantidade de sono, sendo os grandes dormidores os mais prejudicados.

Quanto à matutinidade-vespertinidade, a população humana pode ser dividida em três tipos básicos de acordo com o caráter de matutinidade e vespertinidade. Os tipos matutinos são indivíduos que dormem e acordam cedo, sentindo-se bem dispostos e alertas ao acordar, além de preferirem realizar suas atividades durante o dia e terem um menor desempenho à noite. Os tipos vespertinos são indivíduos que dormem e acordam tarde, sentindo-se bastante sonolentos pela manhã, mas apresentam boa disposição para trabalhar durante a noite. Por último, os tipos indiferentes apresentam uma maior flexibilidade de horários de sono, encontrando-se em uma situação intermediária entre os matutinos e os vespertinos. Os indivíduos matutinos e vespertinos apresentam diferenças em relação: à sensação de alerta e fadiga ao longo do dia, ao ritmo de excreção dos hormônios, ao ritmo de desempenho e ao momento em que ocorrem os valores máximo e mínimo da temperatura corporal (ÅKERSTEDT e FROBERG, 1976; FORET et al, 1982 e 1985; GIANNOTTI et al, 2002; HORNE 
e OSTBERG, 1976; PÁTKAI, 1971; ROENNEBERG et al, 2004; TAKEUCHI et al, 2001).

Também existem pessoas com maior ou menor capacidade para tolerar a sonolência (LAVIE e SEGAL, 1989; ROEHRS et al, 1990). Pessoas sonolentas adormecem facilmente durante o dia e durante a noite. Apresentam elevada eficiência do sono $^{4}$ e quando colocadas em um ambiente propício ao sono, encontram dificuldades em evitar o sono (principalmente quando em situação de privação). Por outro lado, pessoas alertas apresentam maior dificuldade em adormecer e conseguem facilmente resistir ao sono. Segundo LAVIE (1989), o nível de sonolência diurna constitui uma característica individual estável, que junto à estrutura temporal do ciclo vigília-sono, estabelece a marca pessoal da sonolência ultradiana e circadiana.

Durante o desenvolvimento ocorrem modificações nas características do ciclo vigília-sono humano, relacionadas à duração do sono e à distribuição dos episódios ao longo das 24 horas, e à estrutura interna do sono (KLEITMAN, 1963; WEBB, 1968). Nas primeiras semanas após o nascimento, a criança apresenta diversos episódios de sono e vigília distribuídos ao longo do dia e a noite. Os episódios de sono diurno desaparecem ao longo dos primeiros anos de vida, passando-se a ocorrer um episódio de sono durante a noite. A idade de desaparecimento destes episódios de sono diurno varia de maneira significativa entre as crianças (LOUZADA et al, 1996). Em algumas sociedades, um episódio de sono diurno após o almoço, a sesta, é permitido pela sociedade durante a vida adulta (STAMPI, 1992). Em idosos também são observadas algumas alterações dos padrões do ciclo vigília-sono quando comparados com os padrões do adulto mais jovem, em particular, uma fragmentação do sono noturno e cochilos mais freqüentes. Essas alterações, no entanto, parecem estar relacionadas aos hábitos destes idosos, pois CEOLIM (1999) estudando o ciclo vigília-sono de idosos saudáveis e ativos observou que o envelhecimento não é necessariamente acompanhado pela fragmentação do sono, e que essa fragmentação poderia ser

\footnotetext{
${ }^{4}$ Porcentagem da duração do sono em que o indivíduo estava dormindo, excluindo os despertares noturnos e a latência do sono (tempo que o indivíduo levou para adormecer).
} 
decorrente das condições associadas à idade avançada, como a inatividade ou patologias.

Diferenças entre os sexos também são observadas, como uma maior duração de sono nas mulheres em diversas etapas da vida: nos primeiros anos de vida (MENNA-BARRETO et al, 1989), na adolescência (ANDRADE, 1991; LEVY et al, 1986) e na vida adulta (WEVER, 1984).

\subsection{Ciclo vigília-sono em jovens}

Com o início da puberdade, algumas características do ciclo vigília-sono começam a se alterar: os horários de dormir e acordar tornam-se mais tardios, principalmente em situação de menor imposição dos horários escolares (férias e fins-de-semana) (ANDERS et al, 1978; ANDRADE et al, 1993; CARSKADON et al, 1989; MELLO, 1999; STRAUCH e MEIER, 1988; VALDEZ et al, 1996). Observa-se uma tendência à diminuição da duração do sono noturno nos dias de semana com um concomitante aumento da incidência da sonolência diurna, da dificuldade em despertar pela manhã e de problemas relacionados a adormecer a noite (ANDRADE et al, 1993; BEARPARK e MICHIE, 1987; MONTAGNER et al, 1994). Paralelamente, os jovens relatam uma diminuição na qualidade de sono ao longo da adolescência (STRAUCH e MEIER, 1988), o que também é verificado nos estudos realizados com estudantes universitários, sugerindo que esta tendência presente nos adolescentes pode se manifestar em adultos jovens (HAWKINS e SHAW, 1991; JOHNS et al, 1971).

A melatonina ${ }^{5}$ é um dos mais seguros marcadores biológicos utilizados nos estudos com adolescentes. KOLATA (1984) demonstrou que a redução na secreção de melatonina em crianças pode ser um gatilho para a puberdade. Outro estudo (TETSUO et al, 1982), demonstra que durante a puberdade, não há alterações na excreção total de melatonina (6-hydroxymelatonin sulfate-6-OHMS). Recentemente, GRIEFAHN et al (2003) num estudo longitudinal, demonstrou que o crescimento corporal é o fator responsável pelo declínio dos níveis de

\footnotetext{
${ }^{5}$ Hormônio produzido pela glândula pineal que atua como mecanismo de sinalização biológica da fase escura do ciclo claro/escuro em vertebrados (MARQUES e MENNA-BARRETO, 1997).
} 
melatonina no plasma. Para REITER (1998) esse declínio ocorrido na puberdade, está relacionado com a redução da síntese de melatonina pela glândula pineal. Já ACEBO et al (2003), ARENDT (1988), CARSKADON (2004), WALDHAUSER e DIETZEL (1985) e ZEITZER et al (1999) encontraram grande variabilidade nos níveis de melatonina. Esses resultados não são conclusivos, mas essa variabilidade nos resultados encontrados demonstra que a puberdade pode sinalizar uma redução da secreção de melatonina no sistema temporal circadiano. Talvez essa diminuição em adolescentes mais velhos possa auxiliar na tendência de manifestar o atraso de fase do sono ${ }^{6}$, estendendo o período circadiano durante a puberdade, isto é, em alguns adolescentes o dia interno seria mais longo.

As mudanças que ocorrem nas características do ciclo vigília-sono de adolescentes estão relacionadas aos estágios da puberdade. O aumento da sonolência diurna e a tendência a atrasar o horário de início de sono teriam origem em modificações orgânicas características da adolescência (ANDRADE, 1991 e 1997; ANDRADE e MENNA-BARRETO, 1996; CARSKADON et al, 1993). Além disso, fatores psicossociais, como, por exemplo, aumento na quantidade e variedade de atividades sociais e acadêmicas do adolescente, resultam em uma restrição do tempo disponível para o sono (DAHL e CARSKADON 1995). O próprio cotidiano, como por exemplo, a necessidade de acordar cedo para ir à escola ou trabalhar, causa uma privação crônica do sono (TEIXEIRA et al, 2004) (Figura 3).

\footnotetext{
${ }^{6}$ Deslocamento de fase do sono, como por exemplo, a mudança do horário de dormir das $22 \mathrm{~h}$ para as 23h (MARQUES e MENNA-BARRETO, 1997).
} 
Figura 3. Fatores que contribuem para o aumento da sonolência em jovens.

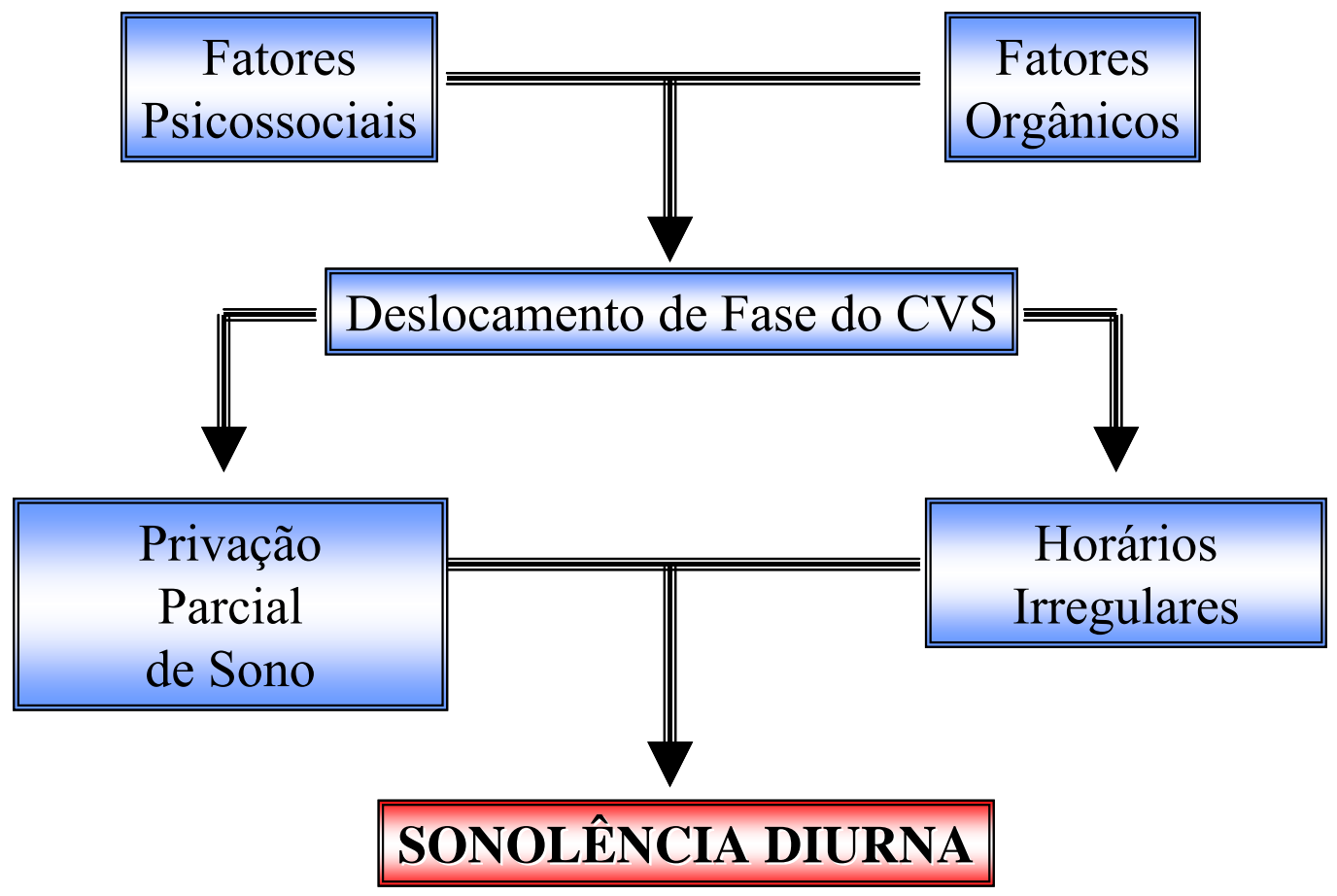

Fonte: ANDRADE, 1997.

O aumento da sonolência diurna seria também, conseqüência da privação de sono aos quais os jovens estão submetidos, devido principalmente aos horários escolares. MELLO (1999) acompanhou um grupo de 33 pré-adolescentes na transição de horários escolares, do turno vespertino para o turno matutino. Os estudantes sofreram privação parcial de sono após a mudança para o turno matutino embora tenham adiantado seus horários de dormir nos dias úteis e finsde-semana. O nível de sonolência diurna aumentou durante o turno matutino, principalmente no início da aula. O número de cochilos durante o dia aumentou e o número de despertares espontâneos diminuiu após a transição. CARSKADON et al (1998) analisaram a sonolência de estudantes após o início das aulas ter sido 
adiantado em cerca de uma hora, e verificaram que as aulas ocorriam numa fase do dia em que os adolescentes estão muito sonolentos provocando uma redução da duração do sono noturno e assim, limitando o adolescente a se adaptar aos horários escolares.

ANDRADE (1997) analisou os padrões temporais das expressões da sonolência diurna em 99 estudantes da cidade de São Paulo, do sexo feminino, com idade média de 16,8 anos, que freqüentavam a escola pública em período integral (7:15h às 17:05h); foi verificado que: a) o nível de sonolência diurna apresentava um padrão temporal caracterizado por maiores valores no início da manhã e menores valores do meio para o fim da tarde, b) a fase e a duração do sono estavam associadas à prevalência de relatos de sonolência diurna, c) o desempenho das adolescentes em testes psicofisiológicos (adição, cancelamento de letras e destreza manual) aumentava ao longo do dia, atingindo um pico do meio para o final da tarde, momento em que também ocorre maior valor da temperatura corporal A eficiência nos testes de cancelamento de letras era maior quanto menor o nível de sonolência das adolescentes.

Outros estudos mostram que o aumento da sonolência diurna nos adolescentes com maior idade poderia não ocorrer, exclusivamente, devido ao débito de sono provocado pelos horários inadequados às necessidades fisiológicas destes jovens. Adolescentes mais "maduros" seriam mais sonolentos, mesmo quando comparadas situações nas quais existam as mesmas oportunidades para dormir (CARSKADON et al, 1980; LEVY et al, 1986). LEVINE et al (1988) compararam o nível de sonolência diurna de um grupo de jovens entre dezoito e vinte e nove anos com um grupo de adultos entre trinta e oitenta anos. Estudantes universitários com elevada eficiência do sono $(\geq 95 \%)$ mostraram uma latência ${ }^{7}$ média diária mais baixa (maior sonolência) do que aqueles com menor eficiência do sono $(\leq 85 \%)$. A relação entre eficiência do sono noturno e a sonolência diurna sugeriu uma restrição de sono moderada em jovens adultos.

\footnotetext{
${ }^{7}$ Tempo que o indivíduo levou para adormecer
} 
MANBER et al (1996) mostraram que dormir e acordar em horários regulares tem um efeito significativo sobre a sonolência diurna, quando não há falta de sono. Eles analisaram por 12 dias estudantes universitários que citaram ter elevado nível de sonolência diurna e horários irregulares de sono. Após recomendação da equipe de pesquisadores, os estudantes passaram a dormir e a acordar em horários semelhantes todos os dias. Decorridas cinco semanas, os pesquisadores observaram que os níveis de sonolência diurna foram significativamente mais baixos, quando comparados com os dados anteriores.

CARSKADON (2004) em seu artigo relata que principalmente os jovens americanos e de classe social elevada, estão sendo seduzidos pela televisão, internet, telefones celulares, vídeo games e o uso de diversos tipos de substâncias estimulantes e depressores do sono (cafeína, álcool, nicotina, energéticos, etc.). Esses fatores associados à falsa promessa de que redução na duração de sono é igual a maior tempo livre, faz com que os adolescentes consigam permanecer acordado por mais tempo, e assim possam realizar muitas atividades, exceto dormir. Maior estimulação, menor duração de sono, atraso no horário de dormir, atraso no horário de acordar durante os fins-de-semana, maior tempo livre, malhumor, infelicidade, fadiga, etc., fazem com que os o ciclo vigília-sono dos jovens esteja desregulado.

Além das alterações no ciclo vigília-sono, o jovem privado de sono pode ter conseqüências como: alterações metabólicas associadas com diabetes (SPIEGEL et al, 1999) e obesidade (GUPTA et al, 2002). O sistema imune pode ser comprometido (SPIEGEL et al, 2002) e queixas de fadiga e alterações no humor tornam-se comuns (WOLFSON e CARSKADON, 1998).

\subsection{Sono e trabalho}

Apesar da existência de um componente biológico nas modificações do ciclo vigília-sono na adolescência, existem diversos fatores sociais que poderiam estar relacionados à sua expressão em adolescentes (CARSKADON, 1990). Horários de trabalho podem reduzir as horas disponíveis para o sono (DAHL e 
CARSKADON, 1995; TEIXEIRA et al, 2004a e b) e também ter influência sobre o atraso de fase do sono (ALLEN, 1992).

Muitos autores realizaram estudos com trabalhadores adultos, mas poucos autores se preocuparam com os adolescentes trabalhadores. A revisão da literatura realizada revelou os trabalhos de CARSKADON et al (1989), VINHA et al (2001) e TEIXEIRA et al (2004a e b). CARSKADON et al (1989), realizaram uma comparação do padrão do ciclo vigília-sono de adolescentes que trabalhavam mais de 20 horas semanais com outros que trabalhavam menos do que 20 horas ou não trabalhavam. Observaram que aqueles que apresentam uma maior carga de trabalho eram mais sonolentos e tinham maiores dificuldades em permanecer acordados na escola.

Em 1991, CARSKADON também analisou a sonolência em grupos de estudantes trabalhadores e não-trabalhadores, que possuíam ou não atividades extracurriculares. Seus resultados mostraram que o número de estudantes que adormecia em sala de aula era maior entre os estudantes trabalhadores, assim como o número de relatos de dormir enquanto dirigiam, correndo o risco de sofrer acidentes fatais.

MACHADO et al (1998) compararam estudantes universitárias trabalhadoras e não trabalhadoras que freqüentavam as aulas à noite. As estudantes não trabalhadoras dormiam e acordavam mais tarde, tinham uma duração do sono maior e os horários de dormir eram mais regulares do que as trabalhadoras.

VINHA et al (2001) e TEIXEIRA et al (2004a) compararam o ciclo vigília-sono de estudantes trabalhadores e não-trabalhadores, em Assis e São Paulo, SP, respectivamente. Os dois estudos chegaram a resultados similares, demonstrando que o ciclo vigília-sono dos adolescentes trabalhadores, comparado com adolescentes não-trabalhadores é caracterizado por: acordar mais cedo e ter menor duração do sono noturno e do sono total durante a semana. Os estudantes trabalhadores também apresentaram maiores dificuldades para acordar e menor qualidade do sono. Nos fins-de-semana dormiam mais cedo, tinham uma duração 
de sono menor e despertavam sozinhos mais facilmente que os adolescentes nãotrabalhadores.

TEIXEIRA et al (2004b) também comparou o tempo gasto na realização das atividades diárias entre adolescentes trabalhadores e não-trabalhadores. Seus resultados demonstravam que a dupla jornada (estudo e trabalho) dos estudantes trabalhadores afeta a duração do sono, o tempo de permanência na escola e a realização de outras atividades extracurriculares, como por exemplo, cursos de línguas, informática e a prática de atividade física.

Adolescentes trabalhadores foram estudados por FISCHER et al (2003a e b). Verificou-se que, tanto os adolescentes trabalhadores da capital quanto do interior do estado de São Paulo que estudavam a noite, relataram uma menor duração do sono do que os adolescentes não-trabalhadores. Particularmente no estudo de FISCHER et al (2003a), que levantou informações através de questionários, foram observados vários fatores associados à menor duração de sono e impactos importantes pelo fato de dormirem menos, tais como: a) os adolescentes trabalhadores do sexo masculino e que ingerem regularmente bebidas alcoólicas apresentaram uma menor duração de sono noturno e do sono total nos fins-de-semana; b) os que dormiam menos referiram: sonolência durante o trabalho e nas aulas, ter dificuldades de se concentrar nos estudos, maior dificuldade para acordar e menor qualidade do sono durante a semana.

A sonolência em adultos está relacionada com a ocorrência de acidentes de trabalho. DINGES et al (1997) referiram que trabalhadores que apresentam média de duração de sono de 4,5 horas por dia tinham sonolência a níveis similares ao da privação total de sono, aumentando consideravelmente as chances de ocorrerem acidentes de trabalho.

O trabalho do adolescente pode ser responsável pela sonolência durante o trabalho e nas aulas, levando a diminuição no tempo utilizado para realizar as tarefas escolares e atividades físicas, maior incidência de uso de substâncias estimulantes e de substâncias alcoólicas, e pela percepção de cansaço crônico (FISCHER et al, 2003a; TEIXEIRA et al, 2005). 


\section{HIPÓTESES}

De acordo com a Figura 3 foi verificado os principais resultados de pesquisas a respeito do ciclo vigília-sono em jovens. A partir do modelo de ANDRADE (1997) e com os resultados dos estudos sobre o ciclo vigília-sono em jovens trabalhadores foi criado um modelo explicativo para a privação de sono nesse grupo (FIGURA 4). É importante destacar que os horários irregulares não aparecem neste modelo, pois o estudante trabalhador possui horários regulares para dormir e acordar durante a semana, ocorrendo o atraso de fase característico da adolescência apenas nos fins-de-semana onde o estudante pode escolher seus horários de sono. Além disso, a carga de trabalho e a fadiga podem aumentar a privação de sono dos estudantes trabalhadores.

Figura 4. Fatores que contribuem para o aumento da sonolência em jovens trabalhadores.

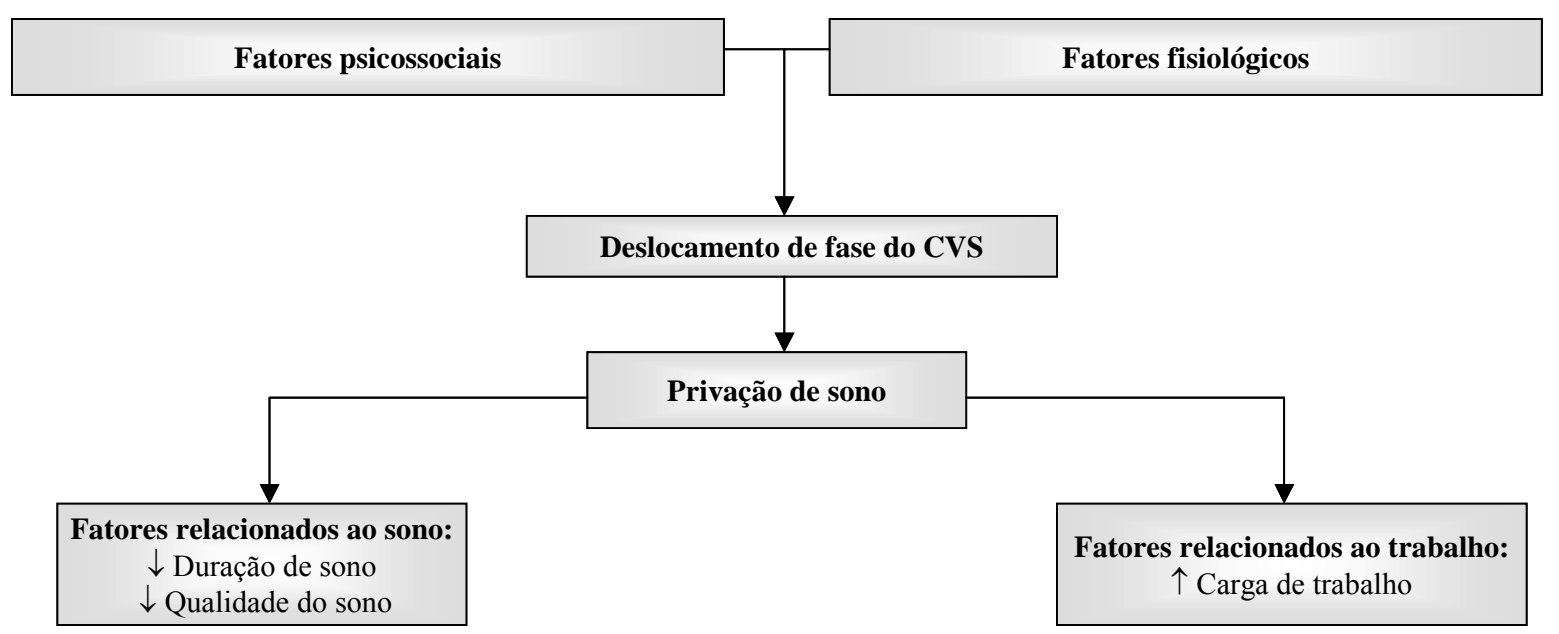

Analisando a Figura 4 é evidente que há muitas lacunas no conhecimento sobre o sono e a sonolência em jovens trabalhadores. Muito pouco se conhece sobre a percepção da sonolência em estudantes trabalhadores. Não se conhecem com que freqüência e intensidade ocorre à sonolência, as expressões da ritmicidade circadiana desta variável, nem suas associações com: o uso de substâncias psicoativas e depressoras do sistema nervoso, qualidade do local onde a pessoa dorme, higiene de sono, comportamento do ciclo vigília-sono, 
particularmente entre jovens trabalhadores. Também não se tem conhecimento das repercussões da sonolência nas atividades diárias (curriculares e extracurriculares), na vida social entre estudantes trabalhadores e nãotrabalhadores. Não se conhecem as estratégias utilizadas pelos estudantes para vencer a sonolência. Também são desconhecidas as relações entre sonolência e tipo de trabalho realizado.

Figura 5. Possíveis inter-relações de variáveis independentes e dependentes, explicativas do sono e da sonolência diurna em jovens trabalhadores e não-trabalhadores.

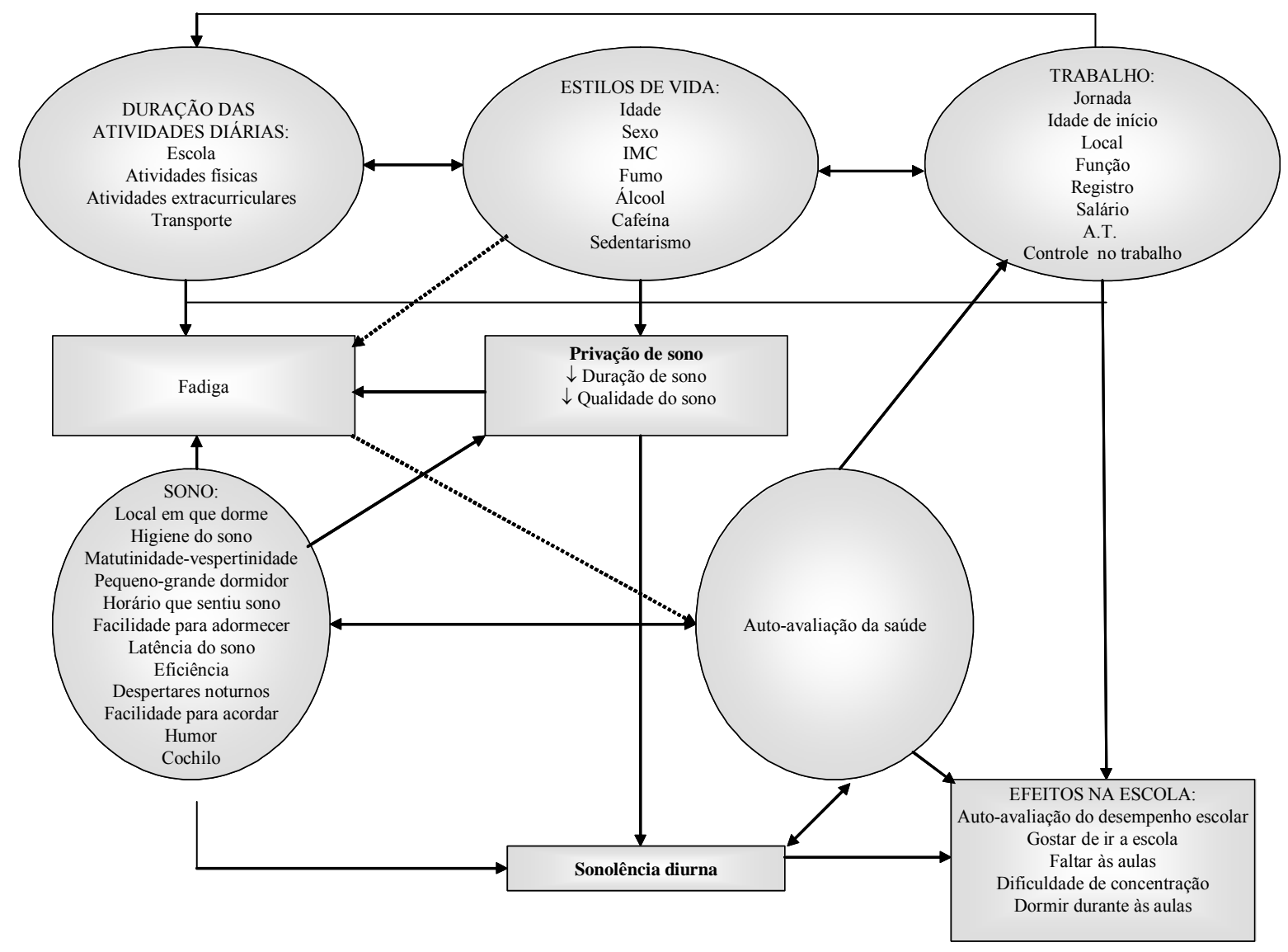

$\mathrm{Na}$ Figura 5 pode-se verificar as possíveis inter-relações de variáveis independentes e dependentes, explicativas do sono e da sonolência diurna em 
jovens trabalhadores e não-trabalhadores. Devido à complexidade do tema, nesta tese serão analisados o ciclo vigília-sono e a sonolência de jovens trabalhadores e não-trabalhadores e suas associações com estilos de vida, duração das atividades diárias e o trabalho. Os efeitos da sonolência no desempenho escolar e as demais associações não são objeto de estudo desta tese.

Neste estudo uma das hipóteses é que o trabalho contribui para o aumento da sonolência durante o trabalho e as aulas. Outra hipótese é que durante os finsde-semana, os jovens trabalhadores, apresentam maiores níveis de sonolência quando comparados com jovens não-trabalhadores.

Além do trabalho, muitos jovens se dedicam a atividades físicas e extracurriculares regulares. Como o tempo gasto nessas atividades pode ser semelhante à jornada de trabalho, a prática dessas atividades aumenta a sonolência diurna.

Outra importante hipótese é que as alterações no ciclo vigília-sono (regularidade ao longo da semana, duração do sono, latência do sono, eficiência do sono, despertares noturnos, cochilos, qualidade do sono, facilidade para dormir e acordar) levariam à privação de sono podendo interferir na sonolência diurna.

Para finalizar, será avaliado se as variáveis sócio-demográficas (sexo, faixa etária) e estilos de vida (IMC, consumo de substâncias psicoativas e depressoras do sistema nervoso e sedentarismo) influenciam na expressão da sonolência diurna. 


\section{OBJETIVOS}

\subsection{Objetivo geral}

Verificar possíveis efeitos das atividades diárias nos níveis de sonolência entre estudantes trabalhadores e não-trabalhadores, alunos de escola pública do município de São Paulo.

\subsection{Objetivos específicos}

- Analisar associações das variáveis que compõem o ciclo vigília-sono e trabalho.

- Identificar os padrões temporais dos relatos de sonolência diurna durante as atividades diárias (nos dias de aula e folga) em estudantes trabalhadores e não-trabalhadores.

- Verificar a relação entre a sonolência diurna e as características do ciclo vigília-sono (regularidade ao longo da semana, duração do sono, latência do sono, eficiência do sono, despertares noturnos, cochilos, qualidade do sono, facilidade para dormir e acordar e as variações de humor) entre estudantes trabalhadores e não-trabalhadores.

- Analisar a associação entre a sonolência diurna e as variáveis sóciodemográficas, estilos de vida, auto-avaliação do desempenho escolar e condições de trabalho. 


\section{METODOLOGIA}

\subsection{AMOSTRAGEM}

\subsubsection{Desenho do Estudo}

Estudo do tipo transversal, o qual permite estudar a situação de exposição e efeito de uma população em um único momento.

\subsubsection{Tamanho da Amostra}

Devido à ausência na literatura de estudos a respeito da sonolência em estudantes trabalhadores, foi realizada uma pré-coleta, em 2002, com estudantes da $3^{\text {a }}$ série do Ensino Médio do período noturno. Com esses resultados, o tamanho da amostra foi calculado a partir da média e dos desvios-padrão dos níveis de sonolência dos estudantes trabalhadores. A média dos níveis de sonolência para os estudantes trabalhadores foi 4,55 e para os não-trabalhadores, 4,18 e o desviopadrão para todos os estudantes foi 0,46 .

Para analisar o efeito do trabalho nos níveis de sonolência foi utilizada a fórmula para comparação de duas médias de HULLEY e CUMMINGS (1988):

$$
\mathrm{T}=\frac{\text { Efeito }}{\text { d.p. }}=\frac{4,55-4,18}{0,46}=0,80
$$

$\mathrm{T}=$ Tamanho da amostra

$\mathrm{E}=$ Efeito esperado (média dos níveis de sonolência para cada grupo trabalhadores e não-trabalhadores)

d.p. = desvio-padrão dos níveis de sonolência dos dois grupos. 
Utilizando a tabela para comparação entre duas médias (HULLEY e CUMMINGS, 1988), $\alpha=5 \%, \beta=10 \%$ e $\mathrm{T}=0,80$, o tamanho da amostra seria de 33 estudantes por grupo de estudo (trabalhadores e não-trabalhadores).

\subsubsection{Perdas na Amostra}

A coleta de dados iniciou-se em agosto de 2002 e terminou em junho de 2004. Não ocorreu coleta de dados nos períodos de férias e nas semanas em que havia algum feriado. O tempo de coleta (24 meses) deveu-se a: às baixas taxas de resposta e de colaboração dos estudantes, as substanciais perdas de seguimento dos participantes e aos constantes defeitos de um dos instrumentos utilizados (actímetros). Após praticamente dois anos de coleta de dados, e por não conseguir mais voluntários, foi decidido terminar a coleta de dados. Assim, o grupo dos estudantes trabalhadores contém 51 estudantes e o grupo dos não-trabalhadores contém 41 estudantes.

Mesmo ultrapassando o tamanho da amostra estabelecido (33 estudantes por grupo), o maior número de perdas ocorreu no grupo dos estudantes nãotrabalhadores. Esses estudantes, por ainda não estarem inseridos no mercado de trabalho, não se sentiram motivados a participar deste estudo.

\subsection{SELEÇÃO DA ESCOLA}

Tendo em vista a necessidade de verificação diária dos instrumentos de pesquisa utilizados no estudo, foram escolhidas escolas pertencentes à diretoria centro-oeste, próximas à Faculdade de Saúde Pública da Universidade de São Paulo para este estudo.

De acordo com informações obtidas na Secretaria de Estado da Educação do Governo do Estado de São Paulo, a escola estadual mais próxima da Faculdade de Saúde Pública, que oferecia Ensino Médio no período noturno e que possuía o maior número de alunos matriculados foi a Escola Fernão Dias Paes. A escola está localizada entre o trabalho e a residência da maioria dos estudantes do Ensino Médio do período noturno. Nesta escola há alunos que residem em diversas 
regiões da cidade de São Paulo, principalmente nos bairros próximos a Rodovia Raposo Tavares. A grande maioria das famílias dos estudantes é de baixa renda (1 a $3 \mathrm{SM})$.

A escola Fernão Dias Paes possuía uma infra-estrutura adequada para a pesquisa, com salas livres em que os alunos foram levados para preencherem os questionários e serem entrevistados. A diretora e a coordenadora do colégio disponibilizaram todas as informações que fossem pertinentes ao estudo principalmente em relação à freqüência dos alunos.

Haviam 16 salas de aula no turno noturno. Das 16 salas, 6 eram destinadas à primeira série, 5 a segunda e 5 à terceira série do Ensino Médio. As aulas do período noturno ocorriam das 19:00 h às 22:30 horas.

Os resultados deste estudo poderão fornecer subsídios ao Centro de Saúde "Geraldo de Paula Souza" da Universidade de São Paulo vinculado à Faculdade de Saúde Pública, que oferece o Programa "Saúde do Adolescente" para jovens que residem nos Bairros de Pinheiros, Jardim América e Vila Madalena.

\subsection{POPULAÇÃO}

Participaram da pesquisa estudantes entre 14 e 21 anos de idade incompletos, alunos do Ensino Médio do período noturno da rede pública estadual, pertencente à diretoria de ensino centro-oeste, que freqüentavam a escola no período das 19:00 às 22:30 horas no município de São Paulo, SP.

\subsection{APRESENTAÇÃO DO PROJETO DE PESQUISA}

Foi realizada uma reunião na escola, onde o projeto de pesquisa foi apresentado à diretora geral, a seus auxiliares (auxiliares da direção e coordenadores pedagógicos) e professores da escola. Enfatizou-se a importância desta pesquisa e discutiu-se o cronograma de trabalho para a aplicação dos protocolos e questionários aos alunos. Posteriormente, mediante a aceitação dos professores, a diretora autorizou o início do estudo. 


\subsection{CRITÉRIOS PARA SELEÇÃO DA POPULAÇÃO}

Foram considerados para este estudo os adolescentes que se encontravam no final do período da puberdade, entre $14-17$ anos de idade e os jovens entre 18 - 21 anos de idade segundo os critérios da OPAS (BREINBAUER, 2005).

Para as análises do ciclo vigília-sono foram utilizados os seguintes critérios de inclusão e exclusão:

- Foi excluído da amostra um estudante que estava tomando medicamentos que interferia no ciclo vigília-sono, além de um indivíduo que relatou distúrbios de sono no questionário de avaliação dos distúrbios do sono (BRAZ et al, 1987).

- Para o grupo de alunos não-trabalhadores, foram considerados aqueles que registraram no questionário que nunca trabalharam ou que estavam desempregados. Este critério baseou-se no estudo de FISCHER et al (2003a), que verificaram semelhanças entre as médias de duração do sono referidas por estudantes desempregados e não-trabalhadores.

- Para obter-se o grupo de estudantes trabalhadores, foi utilizado o mesmo critério utilizado por FISCHER et al (2003a e b) em estudos anteriores: "trabalho é toda atividade sistemática em que há uma obrigatoriedade de desenvolver tarefas, em horários e períodos pré-determinados, seja no ambiente doméstico, seja para terceiros, com ou sem remuneração, tendo ou não vínculo empregatício formalizado".

- Para o grupo de alunos trabalhadores, foram selecionados para a pesquisa alunos trabalhadores com horários e duração de trabalho semelhantes (em torno de 40 horas semanais), para minimizar diferenças nas análises dos horários de acordar, ou mesmo na quantidade de horas trabalhadas diariamente $\mathrm{e}$ semanalmente entre os alunos. Dessa forma, estão neste grupo, alunos que trabalhavam, de segunda à sexta-feira. Para o horário de início do trabalho, foram escolhidos os alunos que acordavam até as 7:30h da manhã. 


\subsection{TERMO DE CONSENTIMENTO (ANEXO 1)}

Após a seleção, todos os estudantes entre 14 e 21 anos de idade foram convidados a participar como voluntários da pesquisa. Os estudantes foram contatados pessoalmente e leram o Termo de Consentimento pós-informação. Todos aceitaram participar voluntariamente do estudo, preenchendo e assinando o documento. Os voluntários menores de 18 anos de idade levaram o termo de consentimento para ser assinado também pelo responsável.

O Termo de Consentimento constou do projeto apresentado ao Comitê de Ética da Faculdade de Saúde Pública da USP de São Paulo, o qual deu parecer favorável à pesquisa (Of. COEP/197/02).

Dentro dos preceitos da Ética em Pesquisa com Seres Humanos (CONSELHO NACIONAL DE SAÚDE, 1996), o termo de consentimento continha informações sobre os objetivos da pesquisa e sobre a destinação científica dos dados para a população estudada, autoridades do ensino e do trabalho, em eventos e publicações científicas. Todos os entrevistados tinham liberdade para abandonar a pesquisa a qualquer momento, sem que isto trouxesse prejuízo à sua pessoa, e era esclarecido que os dados individuais eram mantidos sob sigilo, somente disponíveis para o próprio respondente. Além disso, o pesquisador era responsável por esclarecer todas as dúvidas acerca dos procedimentos, riscos e benefícios e outros assuntos relacionados com a pesquisa.

A devolutiva dos resultados individuais da pesquisa ocorreu durante todo o período de coleta de dados (agosto de 2002 a junho de 2004). 


\subsection{INSTRUMENTOS DE PESQUISA}

\subsubsection{Questionário de Caracterização das Condições de Vida, Saúde e Sono (ANEXO 2)}

Com este protocolo foram obtidas informações a respeito da idade, estado marital, local em que o estudante dorme, hábitos de dormir, cursos e atividades extracurriculares, hábitos de fumo e álcool, atividades físicas e outras atividades no tempo livre, condições de saúde, horários de dormir e acordar, durante a semana e fim-de-semana, cochilos, queixas relacionadas ao sono, sensação de sonolência e cansaço durante a vigília, ingestão de estimulantes e de indutores de sono e do tempo gasto com: transporte, estudo e lazer e o índice de massa corpórea (IMC). As questões relativas ao sono dos estudantes foram adaptadas de protocolos utilizados anteriormente (FISCHER et al, 2003a e b).

Com a duração e freqüência da atividade física desenvolvida pelos estudantes, foi possível classificar os estudantes em sedentários e ativos. Para isso foi utilizado o cálculo do Questionário Internacional de Atividade Física (IPAQ) (CRAIG et al, 2003):

1. Muito ativo: a) realiza atividade física vigorosa $\geq 5$ dias durante a semana em sessões com duração $\geq 30$ minutos, $b$ ) atividade vigorosa $e m \geq 3$ dias durante a semana, em sessões $\geq 20$ minutos acrescidas de atividades moderadas e/ou caminhadas em 5 dias ou mais durante a semana com duração $\geq 30$ minutos/sessão.

2. Ativo: a) realiza atividade física vigorosa em 3 dias ou mais durante a semana com duração de 20 minutos/sessão, b) atividade moderada em 5 dias ou mais durante a semana com duração $\geq 30$ minutos/sessão, c) qualquer atividade somada (caminhada, moderada ou vigorosa) em 5 ou mais dias por semana e com duração $\geq 150$ minutos por semana. 
3. Irregularmente ativo: os que atingem pelo menos um dos critérios da recomendação: a) freqüência: 5 dias na semana ou b) duração: 150 minutos por semana;

4. Sedentário: não realiza atividade física por pelo menos 10 minutos contínuos por semana;

Neste questionário foi incluído o questionário de avaliação dos distúrbios do sono que foi validado por BRAZ et al, 1987, com o objetivo de ser utilizado em estudos epidemiológicos que avaliam queixas de sono nas seguintes categorias: insônia, sonolência excessiva e parassonias. Esse questionário foi validado comparando-se os resultados obtidos através de sua aplicação com os de uma avaliação médica, considerada padrão-ouro. Para se avaliar a insônia foram considerados insones os estudantes que marcaram freqüentemente ou sempre às questões: problema para adormecer, acordar muito durante a noite (mais de 3 vezes) e acordar antes da hora esperada e não conseguir adormecer novamente. Para se avaliar sonolência excessiva foram consideradas as respostas "freqüentemente ou sempre" às questões: ataques de sono incontroláveis, chegando a adormecer em momentos em que não poderia e sente-se muito sonolento(a) durante o dia, de forma a prejudicar as suas atividades. Para distúrbios de sono foram considerados os estudantes que relataram um ou mais dos seguintes distúrbios na última semana: andar, ranger os dentes, engolir e se sufocar, acordar em pânico, chorando ou gemendo, paralisia ao adormecer ou ao despertar, roncar, câimbras, chutar as pernas, gritar dormindo, bater a cabeça, falar dormindo e mexer-se muito.

O questionário apresenta 34 questões (questões 53 a 65 do ANEXO 2) que, além de detectarem a presença ou não de um problema de sono, procuram levantar outras informações, como: impressão subjetiva do entrevistado quanto à qualidade de seu sono; hábitos de horários de sono e vigília; indicativos da gravidade do problema de sono apresentado, como o uso de medicação, procura de auxílio médico e freqüências de apresentação do problema. É um instrumento 
de fácil aplicação e de baixo custo, com uma boa sensibilidade para detecção da presença ou não de doenças relacionadas ao sono.

\subsubsection{Questionário de Identificação do Caráter de Matutinidade e Vespertinidade (ANEXO 3)}

A identificação de diferenças individuais em relação aos ritmos circadianos, principalmente quanto aos momentos de máximo e mínimo de diversas funções, pode ser obtida através do emprego de questionários. $O$ questionário de identificação de matutinidade-vespertinidade desenvolvido por HORNE e OSTBERG (1976) tem sido o mais amplamente utilizado, apresentando um bom grau de discriminação. É composto de 19 questões a respeito de situações habituais da vida diária, onde o indivíduo deve registrar os seus horários preferenciais para estas situações, considerando-se que ele fosse completamente livre para escolher estes horários. O resultado do questionário é um valor numérico, que varia entre 16 e 86 pontos, de acordo com o qual o indivíduo pode ser classificado em cinco tipos diferentes: vespertino extremo, moderadamente vespertino, indiferente, moderadamente matutino, e matutino extremo. Este questionário foi traduzido para a língua portuguesa e aplicado no Brasil, com adaptação da pontuação obtida de acordo com as características e hábitos da população brasileira, para a qual foi validado (BENEDITO-SILVA et al, 1990).

Utilizando as questões: a que horas você gostaria de se levantar e de ir se deitar, se estivesse inteiramente livre para planejar seu dia, foi possível estimar a duração do sono nos dias de folga. Em seguida, utilizou-se o conceito de WEBB (1979) para classificar os estudantes em pequenos dormidores $(<6$ horas de sono), neutros (6 H 9 horas de sono) e grandes dormidores ( $>9$ horas do sono).

\subsubsection{Questionário de Caracterização das Condições de Trabalho}

\section{(ANEXO 4)}


Com este protocolo foram obtidas informações a respeito do trabalho atual, local de trabalho, função exercida, registro em carteira de trabalho, salário, benefícios recebidos, trabalho realizado em casa, tempo gasto para se deslocar para o trabalho e a escola, meio de transporte utilizado, horário de trabalho, descanso e alimentação, sensação de sonolência durante o trabalho, habilidade física e mental exigidas pelo trabalho, cansaço físico e mental (antes e após o trabalho), ambiente de trabalho e acidentes de trabalho. As questões relativas ao trabalho dos estudantes foram adaptadas de protocolos utilizados anteriormente por FISCHER et al (2003a e b). Também foram utilizadas escalas elaboradas por KARASEK (1985), para verificar exigências psicológicas do trabalho, capacidade criativa e demandas físicas que serão descritas a seguir.

\subsubsection{Escalas de Controle no Trabalho}

No estudo conduzido por FISCHER et al (2003a) foi encontrada associação entre menor duração de sono e algumas das sub-escalas do "Job Content Questionnaire" (JCQ) (KARASEK, 1985): maior capacidade de discernimento, menor habilidade criativa, elevadas exigências psicológicas no trabalho e maiores demandas físicas (Physical Exertion). Essas escalas foram acrescentadas ao "Questionário de caracterização das condições de trabalho" para verificarmos se há associação entre elas e os níveis de sonolência dos estudantes trabalhadores.

Após o término da coleta de dados o coeficiente Alpha de Cronbach foi testado para avaliar a consistência interna ou homogeneidade das perguntas (itens) das escalas de controle no trabalho. O resultado para as sub-escalas utilizadas foram: capacidade de discernimento $(\alpha=78 \%)$, exigências psicológicas do trabalho $(\alpha=74 \%)$ e demandas físicas ( $\alpha=81 \%)$. Segundo ROWLAND et al (1991) o valor mínimo de $70 \%$ foi recomendado para considerar-se que os itens avaliam consistentemente a mesma escala.

\subsubsection{Questionário para consumo de cafeína, teobromina e} bebidas alcoólicas (ANEXO 5) 
As técnicas para estimar a ingestão dietética podem ser classificadas em dois grandes grupos: aquelas utilizadas para avaliar o consumo atual (registros e recordatórios); e retrospectivas, freqüentemente utilizadas para avaliar a ingestão habitual de grupos específicos de alimentos/bebidas e para verificar a associação entre consumo alimentar e doença (história dietética e questionário de freqüência alimentar) (GIBSON, 1990).

Em estudos epidemiológicos, um método freqüentemente utilizado para verificar a associação entre dieta e doença é o Questionário de Freqüência de Consumo de Alimentos (QFCA), usado na abordagem do indivíduo sobre seu consumo de determinados alimentos e bebidas. Esse questionário pode fornecer uma estimativa quantitativa do consumo alimentar, incluindo-se informações sobre a porção diária consumida ou, por aproximação, comparando-a a uma porção alimentar de referência. Dentre as vantagens da utilização destes questionários, cita-se o fato de poder ser auto-respondido, aplicado em estudos com grande número de indivíduos, de baixo custo e requerer pouco tempo para completá-lo. Comparado a outros instrumentos, substitui a medição da ingestão alimentar de um ou vários dias pela informação global da ingestão de um período amplo de tempo. O método também permite a estratificação dos resultados em quartis ou quintis de consumo de nutrientes para a análise de tendências de risco, segundo grau de exposição e diferenças entre os níveis extremos de ingestão (WILLETT, 1998).

A reprodutibilidade das informações dos questionários de freqüência é razoavelmente boa, e a validade é aceitável quando se faz a comparação da média de ingestão de nutrientes com outros métodos. Estudos de reprodutibilidade e validade apresentam, com freqüência, coeficientes de correlação da ordem de 0,50 a 0,70 (mais baixos do que as medidas laboratoriais) (WILLETT, 1998).

THOMPSON e BYERS (1994) relatam que esses questionários devem ser ajustados ao invés de validados, porque estudos retrospectivos podem superestimar a ingestão de substâncias em até $20 \%$. A correlação entre o método, para muitos alimentos e nutrientes, está em média entre 0,4 e 0,7. 
DREWNOWOSKI (2001) ressalta que, na ausência da memória dos eventos dietéticos, a pessoa confia nas imagens mentais de sua dieta habitual para estimar a quantidade média do alimento questionado. Assim, esta imagem pode incluir as preferências alimentares e é mais uma inferência do que uma recordação.

\subsubsection{Construção do Questionário}

Com este protocolo foram obtidas informações a respeito da ingestão de substâncias que continham cafeína, teobromina e álcool, a quantidade consumida e a freqüência com que essas substâncias eram consumidas pelos estudantes.

O questionário foi composto por duas listas:

- consumo de cafeína e teobromina contendo 14 itens;

- consumo de bebidas alcoólicas contendo 20 itens.

A seleção dos alimentos e bebidas e de suas formas de preparação, que compuseram o questionário, foi adaptada do instrumento utilizado por PASQUA (2002). Foram acrescentados ao questionário, alimentos e bebidas comumente ingeridos pelos estudantes.

Com o objetivo de aumentar a precisão da informação coletada, classificou-se a periodicidade de consumo alimentar como diário, semanal, mensal e a cada dois meses. Dentro de cada uma dessas categorias, foi registrado o número de vezes que o alimento/bebida era habitualmente ingerido.

A quantidade ingerida e informada, em medidas caseiras, das substâncias selecionadas para comporem o questionário, foram convertidas em gramas mediante a utilização da tabela de medidas caseiras elaborada pelo Departamento de Nutrição da Universidade Federal do Rio de Janeiro (PINHEIRO et al, 1994). A porcentagem de álcool foi levada em consideração segundo a freqüência e o tipo de bebida consumida.

Para o consumo de bebidas alcoólicas, a quantidade ingerida de álcool foi dividida por 0,79, para termos a quantidade de etanol ingerida. Em seguida, este 
valor foi dividido pelo peso do indivíduo para obtermos a dose de álcool ingerida de acordo com o peso corporal.

\subsubsection{Actímetro (ANEXO 6)}

O actímetro é um acelerômetro miniaturizado contendo um cristal piezoelétrico em balanço e deve ser utilizado no pulso não dominante (Basic Mini Motionlogger Actigraph ${ }^{\circledR}$ Ambulatory Monitoring, Inc.). O cristal é um sensor bilaminado, sendo sua voltagem proporcional à mudança de direção de seu movimento. Isto quer dizer que a cada movimento do actímetro é gerada uma voltagem. Este sinal é amplificado, filtrado e comparado com uma voltagem de referência, antes de ser transformado em uma representação digital. Tais representações são agrupadas em intervalos constantes, referidos como épocas (neste caso foi utilizado o período de 1 minuto entre um registro e outro). Os valores acumulados durante uma época são armazenados na memória do aparelho (32K) por no máximo 16 dias e posteriormente transferidos para um computador utilizando como conector uma interface (Auto Actigraph Interface Unit). A detecção e o registro dos dados é realizado através do "Zero Crossing Mode", que conta o número de vezes em cada período de um minuto. Este modo de coleta independe da aceleração estar sendo deslocada acima ou abaixo do limiar da referência. Com a sua utilização, estima-se a freqüência do movimento, sendo a opção de escolha para o estudo do ciclo vigília-sono (SOUZA, 1999; MANUAL Action-W®, 1999).

Com os registros é possível estimar através da quantidade de atividade ocorrida naquele instante, os períodos de sono e vigília de cada indivíduo, a partir da aplicação de um algoritmo. Trata-se de um procedimento automático realizado pelo programa Action-W® (AMBULATORY MONITORING INC., 2001). O algoritmo trabalha com uma equação, construída com constantes específicas. A equação é aplicada aos valores da atividade, gerando resultados expressos em dados binários, sendo 1 o valor atribuído aos momentos em que ocorre o sono, 0 para a vigília, e 2 quando há uma superposição de ambos (quando há incerteza sobre o estado de vigília) em determinado momento. É necessário que os dados 
tenham sido coletados em épocas de 60 segundos. Dois algoritmos foram validados, um por COLE et al (1990), e outro por SADEH, 1996. Ambos os algoritmos possuem uma precisão de aproximadamente $90 \%$ de concordância quando comparados com a polissonografia, que foi tomada como padrão-ouro para a validação dos algoritmos.

Neste estudo, o algoritmo que foi utilizado é o de Sadeh, que ao analisar uma época (ou período), utiliza 11 minutos, sendo, a média da contagem de atividades durante o minuto considerado, os 5 minutos precedentes e os 5 minutos seguintes, levando em consideração o desvio-padrão e o valor mínimo da atividade no período. Este algoritmo também é mais preciso ao se analisar o tempo total de sono, os despertares noturnos e a eficiência do sono. A análise do registro contínuo da atividade fornece dados sobre as seguintes variáveis do ciclo vigília-sono: latência subjetiva do sono noturno (tempo estimado que o estudante leva para adormecer), início e fim da fase de sono, duração do sono noturno, duração dos eventos de despertar durante o sono, duração dos cochilos, duração total do sono (sono noturno + cochilos) e eficiência do sono (porcentagem da duração do sono em que o indivíduo estava dormindo, excluindo os despertares noturnos e a latência do sono). Para os despertares noturnos e os cochilos foram utilizados os eventos $\geq 5 \mathrm{~min}$. Esses eventos foram somados e a duração total analisada.

O uso do actímetro se deve ao fato deste ser um aparelho de maior precisão, capaz de detectar, por exemplo, pequenas interrupções de sono que usualmente não são percebidas pelos indivíduos.

Existem evidentemente limitações nesta estimativa: períodos de vigília em que o indivíduo esteja imóvel (assistindo televisão, por exemplo) poderão ser estimados como períodos de sono, se forem suficientemente duradouros; há, portanto, risco de superestimar os episódios de sono. Por outro lado, períodos de sono mais agitados poderão ser considerados como de vigília, superestimando, por exemplo, as interrupções de sono. Além disso, os períodos em que o aparelho não foi usado serão estimados como sono, se não forem adequadamente identificados. 
Por estes motivos, é indispensável realizar a edição dos dados de vigília e sono obtidos com a aplicação do algoritmo. Esta deve ser bastante cuidadosa, e comparar os registros do Protocolo diário de atividades e do Diário de sono aos do actímetro tendo estes últimos dispostos em forma de gráficos na tela do computador, denominados actogramas.

Os registros do actímetro foram processados automaticamente pelo programa Action-W® (AMBULATORY MONITORING, INC., 2001), que acompanha o actímetro (Figura 6). De acordo com os dados brutos mostrados pelo actímetro e com o diário de sono e os protocolos de atividades preenchidos pelos estudantes, foi feita a edição dos dados no software Action-W® (Figura 7). O intervalo marcado em verde mostra baixa atividade, indicando desde o período que o indivíduo foi se deitar até o período em que se levantou da cama. A linha em vermelho indica os prováveis períodos que o estudante, realmente, estava dormindo. $\mathrm{O}$ intervalo indicado com a faixa rosa indica o período em que o actímetro foi retirado.

Figura 6. Actograma do ciclo vigília-sono de um estudante trabalhador do sexo masculino. São Paulo. 2001.

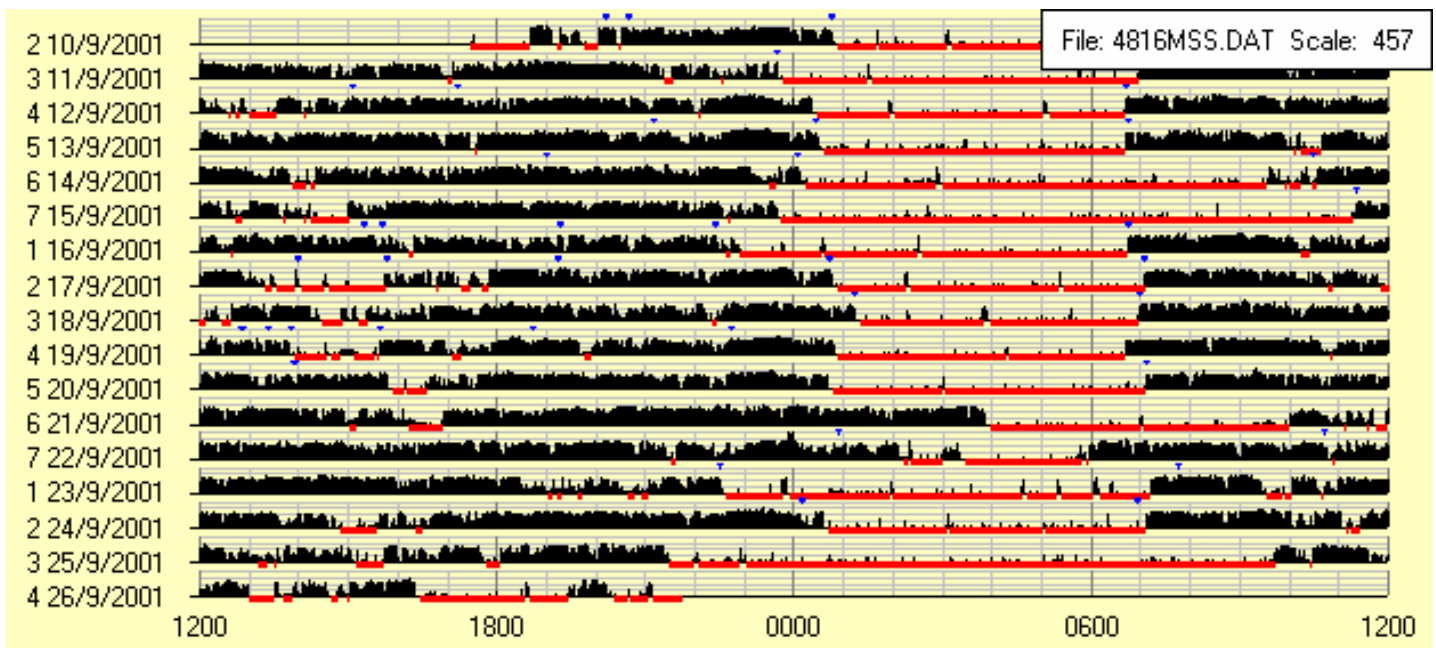


Figura 7. Actograma editado do ciclo vigília-sono de um estudante trabalhador do sexo masculino. São Paulo. 2001.

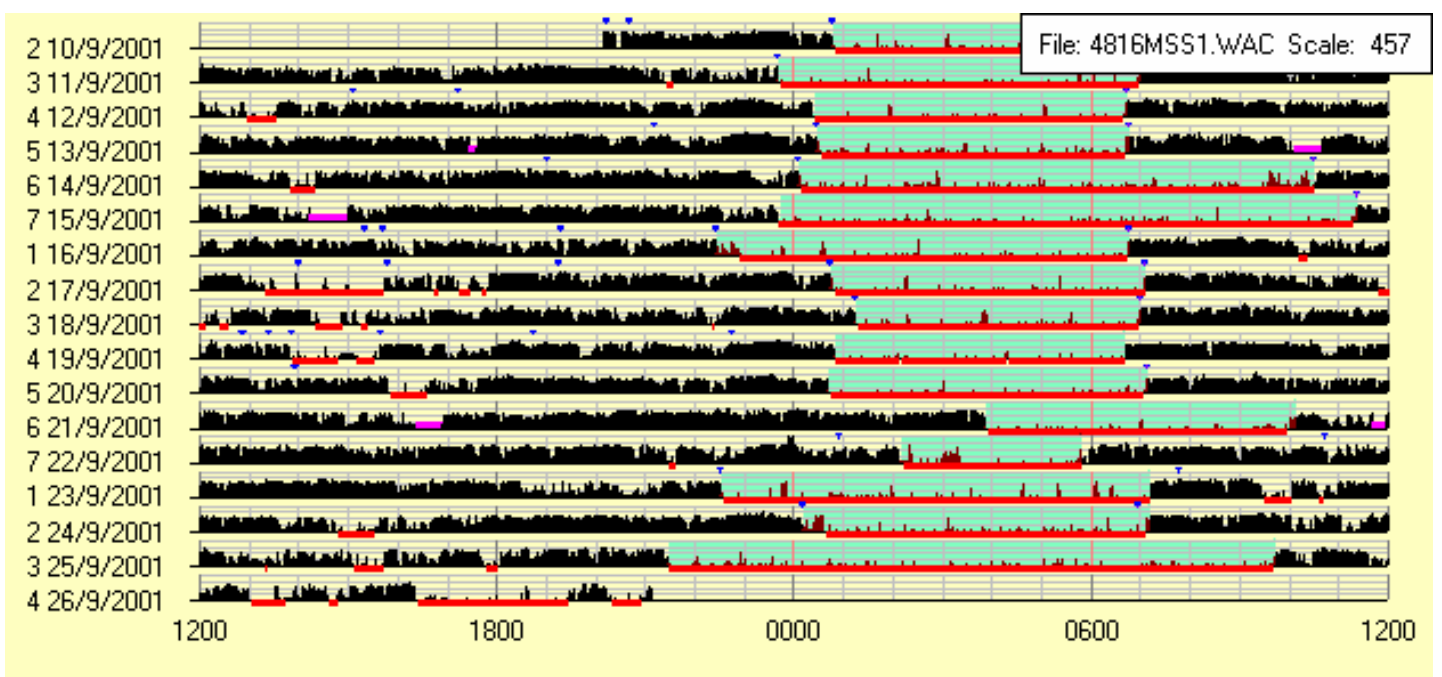

\subsubsection{Protocolo Diário de Atividades e Diário de Sono (ANEXO}

7)

Durante 12 dias consecutivos, os estudantes levaram para casa folhas do protocolo diário de atividade. Ele consiste em uma grade horária de 24 horas dividida em intervalos de tempo de 15 minutos, e apresenta várias opções de atividades. As atividades estão divididas em: trabalho, atividades no lar, transporte, escola, sono, outras atividades (cursos extracurriculares e atividades esportivas) e folga (todas as atividades que não se encaixam nos itens anteriores). $\mathrm{O}$ estudante traçou uma reta que indica o período em que realizou cada uma das atividades apresentadas no instrumento.

Este protocolo foi originalmente idealizado por KNAUTH et al (1983) e adaptado por FISCHER et al (1987) tendo sido utilizado em outros estudos conduzidos por esta pesquisadora.

As sensações subjetivas da qualidade do sono e de facilidade em adormecer à noite, de despertar pela manhã e do humor após acordar, foram quantificadas tendo como referência à posição do traço feito pelo estudante nas escalas analógicas visuais (MONK et al, 1987), que possuem um comprimento de 
$10 \mathrm{~cm}$. As palavras à esquerda (muito difícil, muito ruim) correspondem ao valor zero da escala e à direita (muito fácil, muito boa) ao valor dez. A ausência de valores numéricos dificulta que o indivíduo se lembre das respostas anteriores, o que influenciaria na resposta. Porém, o indivíduo dificilmente conseguirá marcar novamente o mesmo local da escala analógica (baixa confiabilidade). Após a marcação o valor é medido com uma régua para determinação das sensações subjetivas, em até uma casa decimal. As escalas analógicas foram idealizadas para a avaliação de estados afetivos (MONK, 1989), mas são muito utilizadas para a avaliação de sonolência e qualidade de sono em vários estudos.

O diário de sono era composto de perguntas relativas à: latência do sono noturno (tempo estimado que o estudante leva para adormecer), ocorrência, motivo, número e duração dos despertares noturnos, o meio utilizado para despertar (espontaneamente, com o despertador, alguém chamando ou ruídos), tempo estimado que o estudante levou para levantar da cama, realização de cochilos (local, número, horário e duração dos cochilos) e eventuais problemas de saúde e uso de medicação.

\subsubsection{Avaliação subjetiva da sonolência (ANEXO 8)}

Nos protocolos diários de atividade foram anexadas 7 páginas com a escala de sonolência Karolinska (Karolinska Sleepiness Scale). Esta escala é utilizada para a auto-avaliação do nível de alerta do participante da pesquisa (ÅKERSTEDT e GILLBERG, 1990; GILLBERG et al, 1994). A escala contém 9 pontos: muito alerta (1); alerta (3); nem alerta, nem sonolento (5); sonolento mas consegue ficar acordado (7) e muito sonolento, brigando com o sono, muito esforço para ficar acordado (9). Os outros pontos da escala (2,4,6 e 8) não possuem texto explicativo. O indivíduo deverá circular o valor que entender como melhor no momento, precedida da pergunta "Como você está se sentindo agora?".

Cada página representa uma avaliação durante um dos momentos do ciclo vigília-sono. A auto-avaliação da percepção do alerta foi realizada ao acordar, a cada três horas e antes de dormir, durante a fase de vigília por 12 dias 
consecutivos. A avaliação da percepção do alerta também é largamente utilizada por vários autores da área de trabalho em turnos no Brasil e no exterior (ÅKERSTEDT e GILLBERG, 1981; ÅKERSTEDT, 1988; BORGES e FISCHER, 2003; MORENO et al, 2003).

\subsection{ETAPAS DE COLETA DE DADOS}

\subsubsection{Coleta de dados em 2002: primeira etapa}

A coleta de dados ocorreu no período de 12 de agosto a 31 de outubro de 2002, começando uma semana após o início das aulas e terminando alguns dias antes do início do horário de verão. Tanto o início das aulas como o horário de verão, trazem viés para a coleta de dados, pois alteram o ciclo vigília-sono dos estudantes.

Neste ano, apenas os estudantes da terceira série do Ensino Médio do período noturno foram convidados a participar do estudo. Os dados coletados foram utilizados para a definição da amostra. Os alunos da primeira e segunda série foram convidados a participar do estudo em 2003.

Haviam 199 alunos matriculados na terceira série do Ensino Médio do período noturno. Destes, 132 alunos (66,3\%) possuíam entre 14 e 21 anos (Tabela $1)$.

Todos os estudantes que estavam presentes, que estudavam na terceira série do Ensino Médio do período noturno e que possuíam entre 14-21 anos de idade, foram convidados a participar da pesquisa e assinaram o termo de consentimento. Em seguida, 114 estudantes preencheram o "Questionário de caracterização das condições de vida, saúde e sono", o "Questionário de matutinidade-vespertinidade", o "Questionário de caracterização das condições de trabalho" e o "Questionário para consumo de cafeína, teobromina e bebidas alcoólicas". Após o preenchimento, os questionários eram revisados e as incorreções no preenchimento, ou dúvidas das respostas, eram corrigidas. 
Tabela 1. Distribuição segundo série dos alunos matriculados na terceira série do Ensino Médio e das causas de perdas - Colégio Fernão Dias Paes - São Paulo 2002.

\begin{tabular}{|c|c|c|c|c|c|}
\hline \multirow{2}{*}{$\begin{array}{l}2002 \\
\text { Série }\end{array}$} & \multicolumn{3}{|c|}{$\mathrm{N}^{0}$ alunos matriculados } & \multicolumn{2}{|c|}{ Perdas } \\
\hline & $\begin{array}{c}\mathbf{N}^{0} \text { total de } \\
\text { alunos }\end{array}$ & $\begin{array}{l}\mathrm{N}^{\mathrm{O}} \text { alunos entre } 14 \text { - } \\
21 \text { anos incompletos }\end{array}$ & $\begin{array}{c}\mathrm{N}^{0} \text { de alunos excluídos } \\
\text { (> } 21 \text { anos) }\end{array}$ & $\begin{array}{c}\text { Faltosos } \\
\text { freqüientes }\end{array}$ & Transferências \\
\hline $3 \mathrm{~F}$ & 40 & 33 & 07 & 12 & 0 \\
\hline $3 \mathrm{G}$ & 42 & 18 & 24 & 24 & 1 \\
\hline $3 \mathrm{H}$ & 40 & 25 & 15 & 16 & 2 \\
\hline $3 \mathrm{I}$ & 38 & 28 & 10 & 14 & 2 \\
\hline $3 \mathrm{~J}$ & 39 & 28 & 11 & 10 & 4 \\
\hline TOTAL & 199 & 132 & 67 & & 85 \\
\hline
\end{tabular}

Dos 199 alunos, 42,7\% não participaram da pesquisa (85 alunos), sendo: $89,4 \%$ faltosos freqüentes (alunos com avaliação satisfatória em 3 ou mais disciplinas e com mais de 50 faltas durante o primeiro bimestre - 76 alunos) e 10,6\% alunos foram transferidos para outros colégios ( 9 estudantes) (Tabela1).

\subsubsection{Coleta de dados em 2002: segunda etapa}

Obtenção de registros sobre o ciclo vigília-sono de estudantes trabalhadores e não-trabalhadores utilizando métodos subjetivos (Protocolo diário de atividades, diário de sono e escala de sonolência) e objetivos (actímetros).

Todos os alunos que participaram da $1^{\mathrm{a}}$ etapa foram convidados a participar da segunda etapa. Muitos não aceitaram, pois achavam que teriam mais uma atividade para se preocuparem.

Dos 114 estudantes convidados, 48 aceitaram participar. Esses estudantes foram treinados a preencher o Protocolo diário de atividades, o Diário de sono (inclusive medicamentos e ingestão de bebida alcoólica) e a Escala de sonolência, para serem esclarecidas eventuais dúvidas que viessem a surgir. Cada aluno recebeu folhas do protocolo diário de atividades, do diário de sono, as escalas de 
sonolência e instruções quanto ao seu preenchimento, levando-as para casa e trazendo-as no outro dia letivo. Por três dias consecutivos as anotações eram verificadas e as dúvidas esclarecidas. Durante a coleta, foi entregue a cada aluno uma nova folha para que fosse preenchida na manhã seguinte. Foi recolhida a folha que havia sido respondida no dia vigente, durante os dias de aula. Para os fins-de-semana, cada aluno recebeu três folhas para que fossem respondidas no sábado, domingo e segunda-feira e devolvidas na segunda-feita durante a aula. Estes procedimentos foram utilizados para controlar a qualidade do preenchimento, pelo pesquisador.

Os actímetros foram usados simultaneamente pelos estudantes que estavam preenchendo os protocolos diários de atividades, os diários de sono e as escalas de sonolência. Os estudantes foram informados de todos os cuidados que deveriam ter com o aparelho e como deveriam utilizá-lo.

Após a coleta, foram construídos dois grupos: 22 estudantes que trabalhavam e 14 estudantes que não-trabalhavam, totalizando 36 estudantes.

Dos 48 estudantes que participaram desta etapa, ocorreram 12 perdas devido a: quebra ou defeito ocorrido com o equipamento $(\mathrm{N}=6)$. Dois estudantes desistiram e quatro estudantes não utilizaram o aparelho por aproximadamente 2/3 de cada dia, o que inviabilizou a análise dos dados.

O esquema abaixo representa a seqüência da coleta de dados: todos os instrumentos (Protocolo diário de atividades - PDA, Diário de sono -DS e Escala de sonolência - ES) e equipamentos (Actímetros - A) que foram utilizados na segunda etapa. As coletas de dados iniciavam-se na quinta-feira e terminavam na segunda-feira $\left(12^{\circ} \mathrm{dia}\right)$. 


\begin{tabular}{|l|l|l|l|l|l|l|l|}
\hline Semana & Domingo & 2a. feira & 3a. feira & 4a. feira & 5a. feira & 6a. feira & Sábado \\
\hline $\mathbf{1}^{\text {a }}$ semana & treino & treino & treino & $\begin{array}{l}\text { PDA, DS, } \\
\text { ES, A }\end{array}$ & $\begin{array}{l}\text { PDA, DS, } \\
\text { ES, A }\end{array}$ & $\begin{array}{l}\text { PDA, DS, } \\
\text { ES, A }\end{array}$ \\
\hline $\mathbf{2}^{\text {a } \text { semana }}$ & $\begin{array}{l}\text { PDA, DS, } \\
\text { ES, A }\end{array}$ & $\begin{array}{l}\text { PDA, DS, } \\
\text { ES, A }\end{array}$ & $\begin{array}{l}\text { PDA, DS, } \\
\text { ES, A }\end{array}$ & $\begin{array}{l}\text { PDA, DS, } \\
\text { ES, A }\end{array}$ & $\begin{array}{l}\text { PDA, DS, } \\
\text { ES, A }\end{array}$ & $\begin{array}{l}\text { PDA, DS, } \\
\text { ES, A }\end{array}$ & $\begin{array}{l}\text { PDA, DS, } \\
\text { ES, A }\end{array}$ \\
\hline $\mathbf{3}^{\text {a semana }}$ & $\begin{array}{l}\text { PDA, DS, } \\
\text { ES, A }\end{array}$ & $\begin{array}{l}\text { PDA, DS, } \\
\text { ES, A }\end{array}$ & & & & & \\
\hline
\end{tabular}

\subsubsection{Coleta de dados em 2003: primeira etapa}

A segunda coleta de dados ocorreu no período de 3 de março a 31 de outubro de 2003, começando após o carnaval e terminando alguns dias antes do início do horário de verão. Nas semanas em que havia feriados e nas férias de julho não houve coleta de dados, devido principalmente às alterações ocorridas no ciclo vigília-sono dos estudantes.

Neste ano, o colégio possuía 630 alunos matriculados no Ensino Médio do período noturno. Destes, 565 alunos (89,7\%) possuíam entre 14 e 21 anos (Tabela 2).

Todos os estudantes que estavam presentes e que possuíam entre 14-21 anos de idade foram convidados a participar da pesquisa e assinaram o termo de consentimento. Em seguida, 377 estudantes preencheram o "Questionário de caracterização das condições de vida, saúde e sono", o "Questionário de matutinidade-vespertinidade", o "Questionário de caracterização das condições de trabalho" e o "Questionário para consumo de cafeína, teobromina e bebidas alcoólicas”. Após o preenchimento, os questionários eram revisados e as incorreções no preenchimento, ou dúvidas das respostas, eram corrigidas. 
Dos 565 alunos selecionados, 32,7\% não participaram da pesquisa (185 alunos), sendo: $44,9 \%$ desistentes (aluno com número de faltas igual ou superior a 100 por semestre - 83 alunos); 26,5\% faltosos freqüentes (alunos com avaliação satisfatória em 3 ou mais disciplinas e com número de faltas inferior a 100 por semestre - 49 alunos); 27,0\% alunos foram transferidos para outros colégios (50 estudantes) e 1,6\% recusas (alunos que se recusaram a participar da pesquisa -3 alunos) (Tabela 2).

Tabela 2. Distribuição segundo série dos alunos matriculados no Ensino Médio e das causas de perdas - Colégio Fernão Dias Paes. São Paulo. 2003.

\begin{tabular}{cccccccc}
\hline 2003 & \multicolumn{3}{c}{$\mathbf{N}^{\mathbf{0}}$ alunos matriculados } & \multicolumn{4}{c}{ Perdas } \\
\hline Série & $\begin{array}{c}\mathbf{N}^{\mathbf{0}} \text { total de Alunos entre } \\
\text { alunos }\end{array}$ & $\begin{array}{c}\text { Alunos } \\
\mathbf{1 4 - 2 1} \text { anos } \\
\text { incompletos }\end{array}$ & $\begin{array}{c}\text { excluídos } \\
(>\mathbf{2 1} \text { anos) }\end{array}$ & Desistentes & $\begin{array}{c}\text { Faltosos } \\
\text { freqüentes }\end{array}$ & Transferências & Recusas \\
\hline 1a série & 194 & 172 & 22 & 30 & 18 & 18 & - \\
2a série & 199 & 183 & 16 & 29 & 16 & 12 & 3 \\
3a série & 237 & 210 & 27 & 24 & 15 & 20 & - \\
\hline TOTAL & $\mathbf{6 3 0}$ & $\mathbf{5 6 5}$ & $\mathbf{6 5}$ & & & $\mathbf{1 8 5}$ & \\
\hline
\end{tabular}

\subsubsection{Coleta de dados em 2003: segunda etapa}

Dos 377 estudantes convidados, 60 aceitaram participar com o uso de actímetros. Ocorreram 15 perdas devido a: quebra ou defeito ocorrido com o equipamento $(\mathrm{N}=5)$. Uma aluna perdeu um aparelho. Quatro estudantes desistiram e cinco estudantes não utilizaram o aparelho por aproximadamente $2 / 3$ do dia.

\subsubsection{Coleta de dados em 2004: continuação da segunda etapa}

Ao terminar a coleta em 2003, 21 estudantes que responderam aos questionários em 2003 não puderam participar da segunda etapa do estudo, devido: ao pequeno número de actímetros $(\mathrm{n}=10)$ e aos defeitos ocorridos com os equipamentos. Vários estudantes tiveram que repetir o uso do actímetro por uma 
semana (pelo menos). Deste modo, a continuação da segunda etapa da coleta de dados ocorreu no período de 01 de março a 25 de junho de 2004.

Dos 21 estudantes que aceitaram participar, 10 estudantes foram considerados como perda devido a: quebra ou defeito ocorrido com o equipamento $(\mathrm{N}=3)$. Quatro estudantes desistiram e três estudantes não utilizaram o aparelho por aproximadamente $2 / 3$ do dia.

Após finalizar as coletas de dados, os grupos foram constituídos da seguinte forma: 51 estudantes trabalhadores e 41 estudantes não-trabalhadores, totalizando 92 estudantes.

De acordo com o cálculo do tamanho da amostra, o grupo de estudantes trabalhadores e não-trabalhadores ultrapassou o número proposto $(\mathrm{N}=33)$.

\subsection{ANÁLISE ESTATÍSTICA}

Os dados obtidos na primeira etapa da coleta foram submetidos inicialmente à estatística descritiva (distribuição de freqüências, média e desviospadrão). As variáveis analisadas foram: idade, sexo, IMC, estado marital dos estudantes, número de filhos, desempenho escolar, duração dos cursos extracurriculares, hábitos de fumo e álcool, duração das atividades físicas, condições de saúde, situação ocupacional, local de trabalho e função exercida, registro em carteira e salário. As variáveis relacionadas ao controle no trabalho não foram analisadas, por não se mostrarem significantes nas análises iniciais (qui-quadrado com $\mathrm{p}>0,05$ ). As variáveis matutinidade-vespertinidade e pequeno e grande dormidores também não serão analisadas devido ao pequeno número de matutinos e pequenos dormidores.

Os dados obtidos na segunda etapa de coleta também foram submetidos inicialmente à análise descritiva (média e erro-padrão). Os dados em formato original de horas foram convertidos em minutos para viabilizar os cálculos. Foram utilizados os programas SPSS 12.0 e Statistica 6.0. 
Foram calculados as médias e os desvios-padrão, de cada aluno, para cada dia da semana das seguintes variáveis: horário de início do sono noturno, horário de término de sono noturno, duração do sono noturno (diferença entre os horários de dormir e acordar), latência subjetiva do sono noturno (tempo estimado que o estudante leva para adormecer), duração total do despertar noturno (despertares com duração $\geq 5 \mathrm{~min}$ ), eficiência do sono noturno (porcentagem da duração do sono em que o indivíduo estava dormindo, excluindo os despertares noturnos e a latência do sono), facilidade em adormecer à noite (distância do ponto zero na escala analógica), facilidade em despertar pela manhã (distância do ponto zero na escala analógica), qualidade subjetiva do sono noturno (distância do ponto zero na escala analógica), humor (distância do ponto zero na escala analógica), duração total dos cochilos (cochilos com duração $\geq 5$ min), duração das atividades diárias (trabalho, transporte, folga, escola, outras atividades - cursos de línguas, computação, etc).

Devido às diferenças individuais encontradas entre os estudantes, todas as análises do ciclo vigília-sono foram realizadas para cada dia da semana.

Os dados passaram por teste de normalidade (Teste de Shapiro-Wilk) para que fosse possível escolher os testes adequados para a análise estatística. As variáveis apresentaram distribuição normal e foram testadas através do(a):

a) teste t-Student: comparação de médias entre trabalhadores e nãotrabalhadores;

b) análise de variância (ANOVA) de 3 fatores: nas comparações de médias entre grupo de trabalhadores e não-trabalhadores, dia da semana e horário $07+09 \mathrm{~h}, 10 \vdash 12 \mathrm{~h}, 13 \vdash 15 \mathrm{~h}, 16 \vdash 18 \mathrm{~h}, 19+21 \mathrm{~h}$ e 22 - $24 \mathrm{~h}$. Os seis períodos de sonolência foram escolhidos por conterem uma marcação de cada estudante por período. Foram feitas múltiplas comparações utilizando a correção de Tukey-HSD (honest significant diferences).

c) teste de associação do $\chi^{2}$ com correção de Yates: a variável dependente sonolência para cada dia da semana (pontuação na Escala de Sonolência 
Karolinska) foi transformada em variável dicotômica $(0=1-6$ pontos; $1=7$ 9 pontos). Algumas variáveis foram divididas em tercis: consumo de álcool, cafeína e teobromina, duração dos cursos extracurriculares e do estudo fora do horário escolar, saúde referida, duração da atividade física, desempenho escolar referido, duração do tempo livre e salário-mínimo.

d) regressão logística: Finalizando, foi realizada a análise conjunta das variáveis independentes através da regressão logística múltipla para avaliar os fatores associados à sonolência na segunda-feira, de terça a quinta-feira, na sexta-feira, no sábado e no domingo. Como de terça a quinta-feira os estudantes possuem rotinas semelhantes optou-se por realizar apenas uma análise de regressão. Nesses dias, os estudantes que relataram estar sonolentos em no mínimo dois momentos durante o dia foram classificados como sonolentos. $\mathrm{Na}$ análise de regressão foi utilizado o método stepwise forward selection, para a modelagem estatística. As variáveis sócio-demográficas, estilos de vida, duração das atividades diárias, condições de trabalho, auto-avaliação da saúde, efeitos na escola e do ciclo vigília-sono foram as variáveis independentes de interesse. As variáveis trabalhar, duração do sono, hábito de fumar, consumo de bebidas alcoólicas e cafeína e atividade física foram consideradas variáveis de controle por serem potenciais variáveis de confusão da percepção da sonolência. As variáveis sexo e faixa etária também foram selecionadas como variáveis de controle por serem, de acordo com a literatura, importantes fatores que influenciam na análise do sono e sonolência de jovens. A variável permaneceu no modelo sempre que fosse estatisticamente significativa.

Em todas as análises foi considerado o nível de significância $\alpha=5 \%$. 


\section{RESULTADOS}

\subsection{Comparação da população matriculada no ensino médio no período de}

\section{2 a 2003 e da população participante do estudo}

Na tabela 3 verificou-se que a idade média da população estudada é semelhante à da população matriculada no Ensino Médio nos anos de $2002 \mathrm{e}$ 2003. Com relação ao sexo verificou-se que há uma porcentagem menor de homens e uma porcentagem maior de mulheres na população estudada. Para a série verificou-se que na primeira série há uma porcentagem menor de participantes, ao contrário do que se observou na terceira série do Ensino Médio.

Tabela 3. Descrição da população matriculada nos anos de 2002 e 2003 e da população estudada.

\begin{tabular}{l|l|c|c|c}
\hline \multicolumn{1}{c|}{ Variável } & Categorias & $\begin{array}{c}\text { População } \\
\text { 2002 }\end{array}$ & $\begin{array}{c}\text { População } \\
\mathbf{2 0 0 3}\end{array}$ & $\begin{array}{c}\text { População estudada } \\
\text { (92 estudantes) }\end{array}$ \\
\hline $\begin{array}{l}\text { Idade (média e d.p. em } \\
\text { anos) }\end{array}$ & $17,8(1,1)$ & $17,7(1,5)$ & $17,4(1,4)$ \\
\hline \multirow{2}{*}{ Sexo (n \%) } & Masculino & $332(53,5)$ & $357(56,7)$ & $44(47,8)$ \\
\cline { 2 - 5 } & Feminino & $288(46,5)$ & $273(43,3)$ & $48(52,2)$ \\
\hline \multirow{2}{*}{ Série (n \%) } & $1^{\text {a } \text { série }}$ & $193(31,1)$ & $194(30,8)$ & $18(19,6)$ \\
\cline { 2 - 5 } & $2^{\mathrm{a}}$ série & $228(36,8)$ & $199(31,6)$ & $27(29,3)$ \\
\cline { 2 - 5 } & $3^{\mathrm{a}}$ série & $199(32,1)$ & $237(37,6)$ & $47(51,1)$ \\
\hline
\end{tabular}

\subsection{Descrição da população estudada}

A Tabela 4 demonstra as características sócio-demográficas e estilos de vida. Todos os estudantes eram solteiros e não tinham filhos. Com relação às atividades extracurriculares, aproximadamente $65 \%$ dos estudantes não realizavam cursos de computação ou de língua estrangeira. E, aproximadamente $50 \%$ dos estudantes eram sedentários. Com relação ao consumo de cafeína e teobromina, o consumo 
médio de cafeína foi $265,6 \mathrm{mg} /$ dia $($ S.E. $=29,68 \mathrm{mg} / \mathrm{dia}$ ) e de teobromina foi $83,4 \mathrm{mg} / \mathrm{dia}($ S.E. $=9,8 \mathrm{mg})$.

Não foram encontradas entre estudantes trabalhadores e não-trabalhadores diferenças significantes em relação ao: sexo, faixa etária, série, duração das atividades extracurriculares, hábito de fumar, consumo diário de cafeína e teobromina, duração da atividade física semanal e duração do lazer semanal.

Com relação ao hábito de fumar e beber, aproximadamente $70 \%$ dos estudantes não fumavam e 35\% não bebiam. Para os estudantes que bebiam o consumo médio diário de álcool foi $0,42 \mathrm{~g} / \mathrm{kg}$ (S.E. $=0,09 \mathrm{~g} / \mathrm{kg})$. As estudantes do sexo feminino não-trabalhadoras relataram o maior consumo diário de álcool $(0,77 \mathrm{~g} / \mathrm{kg} ; \quad$ S.E. $=0.25 \mathrm{~g} / \mathrm{kg})$ quando comparadas com as estudantes femininas trabalhadoras (média $=0,63 \mathrm{~g} / \mathrm{kg} ;$ S.E. $=0,22 \mathrm{~g} / \mathrm{kg} ; \mathrm{p}=<0,01$ ), estudantes do sexo masculino trabalhadores (média $=0,48 \mathrm{~g} / \mathrm{kg} ; \quad$ S.E. $=0,20 \mathrm{~g} / \mathrm{kg} ; \mathrm{p}=0,02$ ); e nãotrabalhadores (média $=0,58 \mathrm{~g} / \mathrm{kg} ;$ S.E. $=0,24 \mathrm{~g} / \mathrm{kg}$ ); $\mathrm{p}=0,02$ ). 
Tabela 4. Distribuição das características sócio-demográficas e estilos de vida. Estudantes trabalhadores e não-trabalhadores, estudantes do Ensino Médio.

\begin{tabular}{|c|c|c|c|c|c|}
\hline \multirow{2}{*}{ Variável } & \multirow{2}{*}{ Categorias } & \multicolumn{2}{|c|}{ Trabalhadores } & \multicolumn{2}{|c|}{ Não-trabalhadores } \\
\hline & & $\mathbf{n}$ & $\%$ & $\mathbf{n}$ & $\%$ \\
\hline \multirow[b]{2}{*}{ Sexo } & Masculino & 29 & 56,9 & 15 & 36,6 \\
\hline & Feminino & 22 & 43,1 & 26 & 63,4 \\
\hline \multirow{2}{*}{ Faixa etária } & $14-17$ & 26 & 51,0 & 26 & 63,4 \\
\hline & $18-21$ & 25 & 49,0 & 15 & 36,6 \\
\hline \multirow{3}{*}{ Série } & $1^{\mathrm{a}}$ & 7 & 13,7 & 11 & 26,8 \\
\hline & $2^{\mathrm{a}}$ & 15 & 29,4 & 12 & 29,3 \\
\hline & $3^{\mathrm{a}}$ & 29 & 56,9 & 18 & 43,9 \\
\hline \multirow{4}{*}{$\begin{array}{l}\text { Atividades } \\
\text { extracurriculares }\end{array}$} & Não pratica & 35 & 68,6 & 27 & 65,9 \\
\hline & $<6 \mathrm{~h} /$ semana & 4 & 7,8 & 5 & 12,2 \\
\hline & $6-8 \mathrm{~h} / \mathrm{semana}$ & 5 & 9,8 & 3 & 7,3 \\
\hline & $>8 \mathrm{~h} /$ semana & 7 & 13,8 & 6 & 14,6 \\
\hline \multirow{3}{*}{ Hábito de fumar } & Não fuma & 37 & 72,5 & 31 & 75,6 \\
\hline & $<0.5 \mathrm{maço} / \mathrm{dia}$ & 8 & 15,7 & 8 & 19,5 \\
\hline & $>0.5 \mathrm{maço} / \mathrm{dia}$ & 6 & 11,8 & 2 & 24,9 \\
\hline \multirow{4}{*}{ Hábito de beber } & Não bebe & 18 & 35,3 & 14 & 34,1 \\
\hline & $<0.18 \mathrm{~g} / \mathrm{kg}$ & 11 & 21,6 & 9 & 22,0 \\
\hline & $0.18-0.49 \mathrm{~g} / \mathrm{kg}$ & 12 & 23,5 & 8 & 19,5 \\
\hline & $>0.50 \mathrm{~g} / \mathrm{kg}$ & 10 & 19,6 & 10 & 24,4 \\
\hline \multirow{4}{*}{$\begin{array}{l}\text { Consumo de } \\
\text { cafeína }\end{array}$} & Não consome & 6 & 11,8 & 8 & 19,5 \\
\hline & $<116 \mathrm{mg} / \mathrm{dia}$ & 16 & 31,4 & 8 & 19,5 \\
\hline & $116-290 \mathrm{mg} / \mathrm{dia}$ & 15 & 29,4 & 12 & 29,3 \\
\hline & $>290 \mathrm{mg} / \mathrm{dia}$ & 14 & 27,5 & 13 & 31,7 \\
\hline \multirow{4}{*}{$\begin{array}{l}\text { Consumo de } \\
\text { teobromina }\end{array}$} & Não consome & 8 & 15,7 & 10 & 24,4 \\
\hline & $<29 \mathrm{mg} / \mathrm{dia}$ & 11 & 21,6 & 13 & 31,7 \\
\hline & $29-107 \mathrm{mg} / \mathrm{dia}$ & 19 & 37,3 & 6 & 14,6 \\
\hline & $>107 \mathrm{mg} / \mathrm{dia}$ & 13 & 25,5 & 12 & 29,3 \\
\hline \multirow{4}{*}{$\begin{array}{l}\text { Atividade física } \\
\text { (duração) }\end{array}$} & Não pratica & 21 & 41,2 & 24 & 58,5 \\
\hline & $<5 \mathrm{~h} /$ semana & 12 & 23,5 & 6 & 14,7 \\
\hline & $5-8 \mathrm{~h} /$ semana & 10 & 19,6 & 3 & 7,3 \\
\hline & $>8 \mathrm{~h} /$ semana & 8 & 15,7 & 8 & 19,5 \\
\hline \multirow{3}{*}{ Atividade física } & Muito ativo & 5 & 9,8 & 10 & 24,4 \\
\hline & Irregularmente ativo & 21 & 41,2 & 12 & 29,3 \\
\hline & Sedentário & 25 & 49,0 & 19 & 46,3 \\
\hline \multirow{3}{*}{ Duração do lazer } & $<12 \mathrm{~h} / \mathrm{sem}$ & 17 & 33,3 & 11 & 33,3 \\
\hline & $13-30 \mathrm{~h} / \mathrm{sem}$ & 16 & 31,4 & 12 & 36,4 \\
\hline & $>30 \mathrm{~h} / \mathrm{sem}$ & 18 & 35,3 & 10 & 30,3 \\
\hline \multicolumn{2}{|l|}{ Total } & 51 & 100,0 & 41 & 100,0 \\
\hline
\end{tabular}


A Tabela 5 demonstra a freqüência das variáveis relacionadas à escola. Aproximadamente $40 \%$ dos estudantes relataram bom desempenho escolar, $85 \%$ gostavam de ir à escola, $80 \%$ não faltavam muito às aulas, 50\% estudavam mais de $2 \mathrm{hs} /$ semana em casa. Não foram encontradas diferenças significantes entre estudantes trabalhadores e não-trabalhadores em relação as variáveis relacionadas à escola.

Tabela 5. Distribuição das variáveis relacionadas ao estudo. Estudantes trabalhadores e não-trabalhadores, estudantes do Ensino Médio.

\begin{tabular}{llcccc}
\hline \multirow{2}{*}{ Variável } & \multirow{2}{*}{ Categorias } & \multicolumn{2}{c}{ Trabalhadores } & \multicolumn{2}{c}{ Não-trabalhadores } \\
& & $\mathbf{n}$ & $\mathbf{\%}$ & $\mathbf{n}$ & $\mathbf{\%}$ \\
\hline Desempenho & $7-10$ pontos & 21 & 41,2 & 16 & 39,0 \\
escolar referido & $0-6$ pontos & 30 & 58,8 & 25 & 61,0 \\
& & & & & \\
& Gosta & 44 & 86,3 & 35 & 85,4 \\
Gosta de ir à & Neutro & 7 & 13,7 & 4 & 9,8 \\
escola & Não gosta & - & - & 2 & 4,8 \\
& & & & & \\
Falta muito às & Não & 40 & 78,4 & 35 & 85,4 \\
aulas & Sim & 11 & 21,6 & 6 & 14,6 \\
& & & & & \\
Duração do & Não estuda & 18 & 35,3 & 12 & 29,3 \\
estudo fora da & $<1 \mathrm{~h} /$ sem & 7 & 13,7 & 7 & 17,1 \\
escola & $\geq 2 \mathrm{~h} /$ sem & 26 & 51,0 & 22 & 53,7 \\
& & & & & \\
\hline Total & & 51 & $\mathbf{1 0 0 , 0}$ & $\mathbf{4 1}$ & $\mathbf{1 0 0 , 0}$ \\
& & & & & \\
\hline
\end{tabular}

A Tabela 6 demonstra a freqüência das variáveis relacionadas à saúde. Os estudantes relataram ser saudáveis $(75 \%)$, mas aproximadamente $35 \%$ relataram cansaço nos olhos, $65 \%$ cansaço no corpo, $25 \%$ cansaço mental e $65 \%$ moleza no corpo. Não foram encontradas diferenças significantes entre estudantes trabalhadores e não-trabalhadores em relação as variáveis relacionadas à saúde. 
Tabela 6. Distribuição das variáveis relacionadas à saúde. Estudantes trabalhadores e não-trabalhadores, estudantes do Ensino Médio.

\begin{tabular}{|c|c|c|c|c|c|}
\hline \multirow{2}{*}{ Variável } & \multirow{2}{*}{ Categorias } & \multicolumn{2}{|c|}{ Trabalhadores } & \multicolumn{2}{|c|}{ Não-trabalhadores } \\
\hline & & $\mathbf{n}$ & $\%$ & $\mathbf{n}$ & $\%$ \\
\hline \multirow{2}{*}{ Nota para a saúde } & $0-7$ pontos & 13 & 25,5 & 10 & 24,4 \\
\hline & $8-10$ pontos & 38 & 74,5 & 31 & 75,6 \\
\hline \multirow{2}{*}{$\begin{array}{l}\text { Cansaço nos } \\
\text { olhos }\end{array}$} & Não & 34 & 66,7 & 25 & 62,5 \\
\hline & Sim & 17 & 33,3 & 15 & 37,5 \\
\hline \multirow{2}{*}{ Cansaço no corpo } & Não & 16 & 31,4 & 16 & 40,0 \\
\hline & Sim & 35 & 68,6 & 24 & 60,0 \\
\hline \multirow[t]{2}{*}{ Cansaço mental } & Não & 37 & 72,5 & 32 & 80,0 \\
\hline & Sim & 14 & 27,5 & 8 & 20,0 \\
\hline \multirow{2}{*}{ Moleza no corpo } & Não & 18 & 36,0 & 13 & 32,5 \\
\hline & Sim & 32 & 64,0 & 27 & 67,5 \\
\hline Total & & 51 & 100,0 & 41 & 100,0 \\
\hline
\end{tabular}

A Tabela 7 demonstra as características de trabalho dos estudantes trabalhadores.

Os estudantes trabalhavam principalmente em bancos $(66,6 \%)$ e no comércio (21,6\%). A função principal era auxiliar de escritório $(49,0 \%)$. Com relação ao registro em carteira, 57,1\% eram registrados e recebiam entre um e dois saláriosmínimos. Para as escalas de controle no trabalho, $23,5 \%$ dos estudantes tinham baixa habilidade criativa, $42,0 \%$ alta exigência psicológica no trabalho e $2 \%$ alta exigência física. 
Tabela 7. Distribuição das características de trabalho. Estudantes trabalhadores, estudantes do Ensino Médio.

\begin{tabular}{|c|c|c|c|}
\hline Variável & Categorias & $\mathbf{n}$ & $\begin{array}{r}\text { Trabalhadores } \\
\text { \% }\end{array}$ \\
\hline \multirow{4}{*}{$\begin{array}{l}\text { Local de } \\
\text { trabalho }\end{array}$} & Banco & 34 & 66,6 \\
\hline & Comércio & 11 & 21,6 \\
\hline & Indústria & 3 & 5,9 \\
\hline & Outros locais & 3 & 5,9 \\
\hline \multirow{7}{*}{ Função } & $\begin{array}{l}\text { Auxiliar de } \\
\text { escritório }\end{array}$ & 25 & 49,0 \\
\hline & Balconista & 6 & 11,8 \\
\hline & Office-boy & 8 & 15,7 \\
\hline & Ajudante geral & 7 & 13,7 \\
\hline & Doméstica & 2 & 3,9 \\
\hline & $\begin{array}{l}\text { Operador de } \\
\text { teleatendimento }\end{array}$ & 2 & 3,9 \\
\hline & Outras funções & 1 & 2,0 \\
\hline \multirow{2}{*}{$\begin{array}{l}\text { Carteira } \\
\text { assinada }\end{array}$} & Não & 23 & 42,9 \\
\hline & Sim & 28 & 57,1 \\
\hline \multirow{3}{*}{$\begin{array}{l}\text { Salário- } \\
\text { mínimo }\end{array}$} & $\leq 1 \mathrm{SM}$ & 10 & 20,4 \\
\hline & $1-2 \mathrm{SM}$ & 30 & 58,0 \\
\hline & $>2 \mathrm{SM}$ & 11 & 21,6 \\
\hline \multirow{3}{*}{$\begin{array}{l}\text { Habilidade } \\
\text { criativa }\end{array}$} & $12-29$ pontos & 18 & 23,5 \\
\hline & $30-35$ pontos & 21 & 41,2 \\
\hline & $36-48$ pontos & 12 & 35,3 \\
\hline \multirow{3}{*}{$\begin{array}{l}\text { Exigências } \\
\text { psicológicas } \\
\text { do trabalho }\end{array}$} & $09-21$ pontos & 14 & 28,0 \\
\hline & $22-23$ pontos & 15 & 30,0 \\
\hline & $24-36$ pontos & 21 & 42,0 \\
\hline \multirow{3}{*}{$\begin{array}{l}\text { Exigências } \\
\text { físicas }\end{array}$} & $03-06$ pontos & 25 & 50,0 \\
\hline & $07-09$ pontos & 23 & 46,0 \\
\hline & $10-12$ pontos & 2 & 4,0 \\
\hline \multicolumn{2}{|l|}{ Total } & 51 & 100,0 \\
\hline
\end{tabular}

A tabela 8 demonstra as variáveis relacionadas aos hábitos de sono. Com relação às diferenças individuais, foram encontrados 5 estudantes matutinos, 68 neutros e 16 vespertinos. Em relação a ser pequeno e grande dormidor, 1 estudantes era pequeno dormidor $(n=1), 38$ neutros e 53 grandes dormidores. $38,8 \%$ dos trabalhadores e $56,1 \%$ dos não-trabalhadores acordavam facilmente com barulho ou com pessoas entrando em seu quarto. 
Aproximadamente $70 \%$ dos estudantes possuíam maus hábitos de sono, como dormir assistindo tv, ingerir bebidas alcoólicas, cafeína ou fumar antes de dormir, etc. Aproximadamente $40 \%$ dos estudantes relataram ter um local adequado para dormir, e $71,4 \%$ dos estudantes trabalhadores gostariam de poder aumentar a duração do sono $(\mathrm{F}=8,31 ; \mathrm{p}<0,01)$. Não foram encontradas diferenças significantes entre estudantes trabalhadores e não-trabalhadores em relação as variáveis acordar com barulho ou pessoas entrando no quarto, hábito de sono e local em que dorme.

Tabela 8. Distribuição das variáveis relacionadas aos hábitos de sono. Estudantes trabalhadores, estudantes do Ensino Médio.

\begin{tabular}{|c|c|c|c|c|c|}
\hline \multirow{2}{*}{ Variável } & \multirow{2}{*}{ Categorias } & \multicolumn{2}{|c|}{ Trabalhadores } & \multicolumn{2}{|c|}{ Não-trabalhadores } \\
\hline & & $\mathbf{n}$ & $\%$ & n & $\%$ \\
\hline \multirow{3}{*}{$\begin{array}{l}\text { Matutinidade- } \\
\text { Vespertinidade }\end{array}$} & Matutino & 1 & 2,0 & 4 & 10,2 \\
\hline & Neutro & 37 & 74,0 & 31 & 79,5 \\
\hline & Vespertino & 12 & 24,0 & 4 & 10,3 \\
\hline \multirow{3}{*}{$\begin{array}{l}\text { Pequeno-Grande } \\
\text { dormidor }\end{array}$} & Pequeno & - & - & 1 & 2,4 \\
\hline & Neutro & 20 & 39,2 & 18 & 43,9 \\
\hline & Grande & 31 & 60,8 & 22 & 53,7 \\
\hline \multirow{2}{*}{$\begin{array}{l}\text { Acordar com } \\
\text { barulho/pessoas }\end{array}$} & Não & 30 & 61,2 & 18 & 43,9 \\
\hline & Sim & 19 & 38,8 & 23 & 56,1 \\
\hline \multirow[t]{2}{*}{ Hábito de sono } & Bom & 12 & 23,5 & 14 & 34,1 \\
\hline & Mal & 39 & 76,5 & 27 & 65,9 \\
\hline \multirow{2}{*}{$\begin{array}{l}\text { Local em que } \\
\text { dorme }\end{array}$} & Adequado & 24 & 47,1 & 16 & 39,0 \\
\hline & Inadequado & 27 & 52,9 & 25 & 61,0 \\
\hline \multirow{3}{*}{$\begin{array}{l}\text { Gostaria de alterar } \\
\text { duração do sono }\end{array}$} & Aumentando & 30 & 71,4 & 8 & 32,0 \\
\hline & Diminuindo & 3 & 7,1 & 6 & 24,0 \\
\hline & Variando & 9 & 21,4 & 11 & 44,0 \\
\hline Total & & 51 & 100,0 & 41 & 100,0 \\
\hline
\end{tabular}

\subsection{Padrões de sono}

De acordo com a tabela 9 verificamos efeito do trabalho no início e fim do sono noturno de domingo a quinta-feira $(p \leq 0,04)$. Nesses dias da semana os estudantes trabalhadores iniciavam o sono por volta da meia-noite e acordavam em torno das $7 \mathrm{~h}$, enquanto os estudantes não-trabalhadores iniciavam o sono após a meia-noite e acordavam após as $9 \mathrm{~h}$. 
Com relação à duração do sono noturno, verificamos efeito do trabalho nos seguintes dias da semana: Segunda-feira $\left[\mathrm{t}_{(1,89)}=3,52 ; \mathrm{p}<0,01\right]$, Terça-feira $\left[\mathrm{t}_{(1,90)}=5,34 ; \mathrm{p}<0,01\right]$, Quarta-feira $\left[\mathrm{t}_{(1,90)}=7,70 ; \mathrm{p}<0,01\right]$, Quinta-feira $\left[\mathrm{t}_{(1,90)}=4,34\right.$; $\mathrm{p}<0,01]$ e Domingo $\left[\mathrm{t}_{(1,90)}=2,68 ; \mathrm{p}<0,01\right]$. Nesses dias da semana a duração média do sono dos estudantes trabalhadores foi em torno de 7,2h (S.E.=13.44min), enquanto a duração do sono dos estudantes não-trabalhadores foi em média $8,8 \mathrm{~h}$ $(\mathrm{S} . \mathrm{E} .=16.08 \mathrm{~min})(\mathrm{t}=4,72 ; \mathrm{p}<0,01)$. Nos fins-de-semana a duração do sono foi similar para os grupos $(\mathrm{t}=0,23 ; \mathrm{p}=0,83)$ : trabalhadores média de $7,8 \mathrm{~h}$; (S.E.=16,7min) e não-trabalhadores média de 7,9h (S.E.=18,0.0min). Porém, os estudantes não-trabalhadores, tinham a mesma duração do sono quando comparados com os dias da semana $(\mathrm{t}=0,97 ; \mathrm{p}=0,34)$ o mesmo não ocorrendo com os trabalhadores $(\mathrm{t}=2,6 ; \mathrm{p}=0,01)$.

Avaliando-se a eficiência do sono noturno, apenas da sexta-feira para o sábado foi encontrado o efeito do trabalho $\left[\mathrm{t}_{(1,90)}=2,30 ; \mathrm{p}=0,02\right]$. Neste dia, os estudantes trabalhadores apresentaram uma melhor eficiência do sono $(96,55 \%$;S.E. $=0,38 \%)$ quando comparados com os estudantes não-trabalhadores $(90,12 \% ;$ S.E. $=3,25 \%)$.

Os despertares durante a noite também estavam associados com o trabalho na segunda-feira $\left[\mathrm{t}_{(1,72)}=3,45 ; \mathrm{p}<0,01\right]$, terça-feira $\left[\mathrm{t}_{(1,62)}=2,28 ; \mathrm{p}=0,03\right]$ e domingo $\left[\mathrm{t}_{(1,80)}=1,98 ; \mathrm{p}=0,05\right]$. Na segunda-feira, os estudantes não-trabalhadores tinham maior duração média dos despertares noturnos $(29,06 \mathrm{~min}$; S.E. $=5,11 \mathrm{~min})$ quando comparados com os estudantes trabalhadores $(24,21 \mathrm{~min}$; S.E. $=7,00 \mathrm{~min})$. Nos outros dias, os estudantes trabalhadores tinham maior duração média dos despertares noturnos (terça-feira - 22,35min; S.E. $=5,03 \mathrm{~min}$ e domingo 14,17min; S.E. $=1,85 \mathrm{~min}$ ) quando comparados com os estudantes nãotrabalhadores (terça-feira - 13,20min; S.E.=1,08min e domingo - 13,68min; S.E. $=1,92 \mathrm{~min})$.

Em relação aos cochilos, foi verificado efeito significativo do trabalho na segunda-feira $\left[\mathrm{t}_{(1,32)}=2,26 ; \mathrm{p}=0,03\right]$, terça-feira $\left[\mathrm{t}_{(1,25)}=2,28 ; \mathrm{p}=0,04\right]$, sexta-feira $\left[\mathrm{t}_{(1,33)}=2,24 ; \mathrm{p}=0,03\right]$ e domingo $\left[\mathrm{t}_{(1,38)}=4,02 ; \mathrm{p}<0,01\right]$. Na segunda e terça-feira os 
estudantes trabalhadores apresentaram a maior duração dos cochilos (segundafeira - 58,63min; S.E. $=27,87 \mathrm{~min}$ e terça-feira $-121,06 \mathrm{~min}$; S.E. $=45,65 \mathrm{~min}$ ) e, na sexta-feira e no domingo os estudantes não-trabalhadores tinham a maior duração média dos cochilos (sexta-feira $-116 \mathrm{~min} ;$ S.E. $=53,33 \mathrm{~min}$ e domingo $124,21 \mathrm{~min} ;$ S.E. $=29,98 \mathrm{~min}$ ).

Para a regularidade do sono encontramos diferenças significativas na segunda-feira $\quad(\mathrm{F}=6,50 ; \mathrm{p}<0,01)$, terça-feira $\quad(\mathrm{F}=4,98 ; \mathrm{p}<0,01)$, quarta-feira $(F=4,41 ; p<0,01)$, sexta-feira $(F=3,85 ; p<0,01)$ e no domingo $(F=3,23 ; p<0,01)$. Nos dias da semana o estudante trabalhador teve o meio período do sono em torno das 3:00 h enquanto o estudante não-trabalhador próximo às 5:00 h. No domingo, o meio período do sono sofria um arrastamento e o estudante trabalhador teve o meio período do sono próximo às 5:00 h e os não-trabalhadores próximo às 6:00 h (Tabela 10).

Ao analisarmos o horário que o estudante sentiu sono encontramos diferenças significativas na quarta $(2,14 ; \mathrm{p}=0,04)$ e quinta-feira $(3,73 ; \mathrm{p}<0,01) . \mathrm{Na}$ quarta-feira o estudante não-trabalhador sentia sono às 20:23h enquanto o estudante trabalhador próximo às 23:00 h. Entretanto, o erro-padrão é próximo há uma hora e meia (85min) para os estudantes não-trabalhadores, o que interfere na interpretação do resultado. Na quinta-feira o estudante trabalhador sentia sono no mesmo horário enquanto o estudante não-trabalhador às 00:10h (Tabela 10). 
Tabela 9. Média, erro-padrão e teste t-Student das características de sono. Estudantes trabalhadores e não-trabalhadores, Ensino Médio. São Paulo, SP.

\begin{tabular}{|c|c|c|c|c|c|c|c|c|c|}
\hline \multirow{2}{*}{ Dia } & \multirow{2}{*}{ Variáveis* } & \multicolumn{3}{|c|}{ Trabalhadores } & \multicolumn{3}{|c|}{ Não-trabalhadores } & \multirow{2}{*}{ t test } & \multirow[b]{2}{*}{$\mathbf{p}$} \\
\hline & & $\mathbf{N}$ & Média & S.E. & $\mathbf{N}$ & Média & S.E. & & \\
\hline \multirow{7}{*}{$2^{a}-3^{a}$ feira } & Início do sono & 51 & 23,5 & 10,7 & 41 & 01,1 & 21,3 & 6,97 & $<0,01$ \\
\hline & Fim do sono & 51 & 6,9 & 12,5 & 41 & 10,3 & 28,2 & 6,48 & $<0,01$ \\
\hline & Duração do sono & 51 & 423,41 & 14,90 & 40 & 511,03 & 20,75 & 3,52 & $<0,01$ \\
\hline & Eficiência (\%) & 51 & 93,54 & 1,76 & 40 & 93,72 & 1,00 & 0,08 & 0,93 \\
\hline & Latência & 51 & 17,63 & 5,48 & 40 & 13,63 & 2,82 & 0,60 & 0,55 \\
\hline & Duração dos despertares noturnos & 39 & 24,21 & 7,00 & 35 & 29,06 & 5,11 & 3,45 & $<0,01$ \\
\hline & Duração dos cochilos & 19 & 58,63 & 27,87 & 15 & 41,07 & 12,54 & 2,26 & 0,03 \\
\hline \multirow{7}{*}{$3^{a}-4^{a}$ feira } & Início do sono & 51 & 23,9 & 9,1 & 41 & 24,9 & 11,4 & 2,84 & 0,02 \\
\hline & Fim do sono & 51 & 7,2 & 19,2 & 41 & 8,5 & 22,2 & 2,96 & 0,02 \\
\hline & Duração do sono & 51 & 417,06 & 14,75 & 41 & 543,07 & 18,89 & 5,34 & $<0,01$ \\
\hline & Eficiência (\%) & 51 & 95,95 & 0,95 & 41 & 95,69 & 0,65 & 0,22 & 0,83 \\
\hline & Latência & 50 & 10,84 & 2,71 & 41 & 12,22 & 1,30 & 0,43 & 0,67 \\
\hline & Duração dos despertares noturnos & 23 & 22,35 & 5,03 & 41 & 13,20 & 1,08 & 2,28 & 0,03 \\
\hline & Duração dos cochilos & 16 & 121,06 & 45,65 & 11 & 17,09 & 2,35 & 2,28 & 0,04 \\
\hline \multirow{7}{*}{$4^{a}-5^{a}$ feira } & Início do sono & 51 & 23,5 & 9,5 & 41 & 24,4 & 13,1 & 3,60 & $<0,01$ \\
\hline & Fim do sono & 51 & 7,4 & 17,2 & 41 & 8,6 & 27,3 & 2,23 & 0,03 \\
\hline & Duração do sono & 51 & 404,75 & 9,63 & 41 & 534,49 & 14,50 & 7,70 & $<0,01$ \\
\hline & Eficiência (\%) & 51 & 95,75 & 0,54 & 41 & 95,50 & 0,38 & 0,36 & 0,72 \\
\hline & Latência & 46 & 12,50 & 2,91 & 41 & 17,29 & 2,37 & 1,26 & 0,21 \\
\hline & Duração dos despertares noturnos & 38 & 19,29 & 3,37 & 41 & 17,34 & 1,71 & 0,53 & 0,60 \\
\hline & Duração dos cochilos & 12 & 66,50 & 24,33 & 14 & 21,43 & 4,20 & 1,97 & 0,06 \\
\hline \multirow{7}{*}{$5^{\mathrm{a}}-6^{\mathrm{a}}$ feira } & Início do sono & 51 & 24,1 & 14,6 & 41 & 24,9 & 17,5 & 2,28 & 0,04 \\
\hline & Fim do sono & 51 & 7,9 & 16,4 & 41 & 8,9 & 23,4 & 3,10 & 0,03 \\
\hline & Duração do sono & 51 & 440,55 & 12,10 & 41 & 520,46 & 13,96 & 4,34 & $<0,01$ \\
\hline & Eficiência (\%) & 51 & 96,55 & 0,44 & 41 & 96,67 & 0,36 & 0,22 & 0,83 \\
\hline & Latência & 45 & 8,93 & 1,43 & 41 & 10,83 & 1,65 & 0,87 & 0,39 \\
\hline & Duração dos despertares noturnos & 39 & 16,13 & 2,21 & 36 & 14,89 & 1,92 & 0,42 & 0,68 \\
\hline & Duração dos cochilos & 25 & 43,60 & 10,50 & 19 & 46,37 & 14,22 & 0,16 & 0,87 \\
\hline \multirow{7}{*}{$\begin{array}{l}6^{\mathrm{a}} \text { feira- } \\
\text { Sábado }\end{array}$} & Início do sono & 51 & 24,0 & 15,1 & 41 & 24,0 & 18,5 & 0,11 & 0,91 \\
\hline & Fim do sono & 51 & 7,7 & 20,5 & 41 & 7,8 & 21,3 & 0,20 & 0,84 \\
\hline & Duração do sono & 51 & 453,63 & 15,49 & 41 & 455,17 & 22,48 & 0,06 & 0,95 \\
\hline & Eficiência (\%) & 51 & 96,88 & 0,38 & 41 & 90,12 & 3,25 & 2,30 & 0,02 \\
\hline & Latência & 47 & 10,06 & 1,48 & 41 & 15,56 & 2,98 & 1,72 & 0,09 \\
\hline & Duração dos despertares noturnos & 33 & 14,17 & 1,85 & 41 & 13,68 & 1,92 & 0,92 & 0,36 \\
\hline & Duração dos cochilos & 24 & 31,65 & 8,54 & 11 & 116,00 & 53,33 & 2,24 & 0,03 \\
\hline
\end{tabular}


Tabela 9 (cont.). Média, erro-padrão e teste t-Student das características de sono.

Estudantes trabalhadores e não-trabalhadores, Ensino Médio. São Paulo, SP.

\begin{tabular}{|c|c|c|c|c|c|c|c|c|c|}
\hline \multirow{2}{*}{ Dia } & \multirow{2}{*}{ Variáveis* } & \multicolumn{3}{|c|}{ Trabalhadores } & \multicolumn{3}{|c|}{ Não-trabalhadores } & \multirow{2}{*}{ t test } & \multirow{2}{*}{$\mathbf{p}$} \\
\hline & & $\mathbf{N}$ & Média & S.E. & $\mathbf{N}$ & Média & S.E. & & \\
\hline \multirow{7}{*}{$\begin{array}{l}\text { Sábado- } \\
\text { Domingo }\end{array}$} & Início do sono & 51 & 24,7 & 20,1 & 41 & 1,17 & 22,3 & 0,90 & 0,37 \\
\hline & Fim do sono & 51 & 9,1 & 16,5 & 41 & 9,7 & 19,7 & 1,27 & 0,21 \\
\hline & Duração do sono & 51 & 484,14 & 17,89 & 41 & 493,22 & 13,51 & 0,39 & 0,70 \\
\hline & Eficiência $(\%)$ & 51 & 95,42 & 0,54 & 41 & 95,77 & 0,85 & 0,36 & 0,72 \\
\hline & Latência & 49 & 13,35 & 1,73 & 41 & 14,39 & 4,18 & 0,25 & 0,81 \\
\hline & Duração dos despertares noturnos & 43 & 18,42 & 3,20 & 35 & 17,34 & 4,79 & 0,19 & 0,85 \\
\hline & Duração dos cochilos & 22 & 78,18 & 23,19 & 28 & 72,50 & 19,43 & 0,19 & 0,85 \\
\hline \multirow{7}{*}{$\begin{array}{l}\text { Domingo- } \\
2^{\text {a }} \text { feira }\end{array}$} & Início do sono & 51 & 24,6 & 20,5 & 41 & 1,5 & 23,9 & 2,26 & 0,03 \\
\hline & Fim do sono & 51 & 7,4 & 20,9 & 41 & 9,6 & 21,7 & 3,6 & $\mathbf{0 , 0 2}$ \\
\hline & Duração do sono & 51 & 477,27 & 15,84 & 41 & 533,05 & 12,28 & 2,68 & $\mathbf{0 , 0 1}$ \\
\hline & Eficiência (\%) & 51 & 96,88 & 0,38 & 41 & 96,20 & 0,43 & 1,18 & 0,24 \\
\hline & Latência & 47 & 8,89 & 1,50 & 39 & 13,62 & 2,46 & 1,70 & 0,09 \\
\hline & Duração dos despertares noturnos & 41 & 34,06 & 1,76 & 36 & 18,19 & 2,62 & 1,98 & 0,05 \\
\hline & Duração dos cochilos & 26 & 31,19 & 5,77 & 14 & 124,21 & 29,98 & 4,02 & $<0,01$ \\
\hline
\end{tabular}

\subsection{Percepção da qualidade do sono, humor e facilidade para}

\section{dormir e acordar}

Não foram encontradas diferenças significativas entre trabalhadores e nãotrabalhadores para a facilidade em adormecer e a qualidade do sono (Tabela 14).

Facilidade para acordar: $\mathrm{Na}$ quarta-feira foi encontrada diferença significativa entre os grupos $(\mathrm{F}=2,17 ; \mathrm{p}=0,03)$. Era mais difícil para o trabalhador despertar (média=4,33; S.E.=0,41) quando comparado com o estudante nãotrabalhador (média=5,74;S.E.0,52).

Humor: No domingo foi encontrada diferença significativa para o humor entre os estudantes $(\mathrm{F}=2,29 ; \mathrm{p}=0,02)$. Os trabalhadores estavam mais bem humorados (média=7,58;S.E. $=0,33$ ) quando comparados com os nãotrabalhadores (média $=6,30 ;$ S.E. $=0,47$ ). 
Tabela 10. Média, erro-padrão e test t-Student das escalas subjetivas, regularidade do sono e horário que sentiu sono.

\begin{tabular}{|c|c|c|c|c|c|c|c|}
\hline \multirow{2}{*}{ Dia } & \multirow{2}{*}{ Variável } & \multicolumn{2}{|c|}{ Trabalhadores } & \multicolumn{2}{|c|}{ Não-trabalhadores } & \multirow{2}{*}{ Teste $\mathbf{t}$} & \multirow{2}{*}{$\mathbf{p}$} \\
\hline & & Média & S.E. & Média & S.E. & & \\
\hline \multirow{6}{*}{ Segunda-feira } & Horário que sentiu sono & $22: 58$ & 17,89 & $23: 42$ & 20,03 & 1,63 & 0,11 \\
\hline & Meio do sono & 3,20 & 0,16 & 5,67 & 0,37 & 6,50 & 0,00 \\
\hline & Facilidade adormecer & 7,21 & 0,35 & 6,65 & 0,46 & 0,97 & 0,33 \\
\hline & Facilidade acordar & 6,41 & 1,68 & 6,15 & 0,48 & 0,13 & 0,89 \\
\hline & Humor & 6,99 & 0,317 & 5,99 & 0,45 & 1,86 & 0,07 \\
\hline & Qualidade sono & 6,44 & 0,39 & 6,41 & 0,40 & 0,05 & 0,96 \\
\hline \multirow{6}{*}{ Terça-feira } & Horário que sentiu sono & $22: 58$ & 16,02 & $23: 40$ & 17,70 & 1,73 & 0,09 \\
\hline & Meio do sono & 3,36 & 1,29 & 4,79 & 1,45 & 4,98 & 0,00 \\
\hline & Facilidade adormecer & 7,36 & 0,30 & 7,05 & 0,34 & 0,69 & 0,49 \\
\hline & Facilidade acordar & 4,81 & 0,45 & 5,52 & 0,48 & 1,10 & 0,28 \\
\hline & Humor & 6,21 & 0,36 & 6,27 & 0,40 & 0,12 & 0,91 \\
\hline & Qualidade sono & 6,95 & 0,31 & 6,43 & 0,38 & 1,06 & 0,29 \\
\hline \multirow{6}{*}{ Quarta-feira } & Horário que sentiu sono & 22:58 & 12,33 & 20:23 & 85,06 & 2,14 & 0,04 \\
\hline & Meio do sono & 3,23 & 1,42 & 4,75 & 1,88 & 4,41 & 0,00 \\
\hline & Facilidade adormecer & 7,06 & 0,41 & 6,65 & 0,42 & 0,69 & 0,50 \\
\hline & Facilidade acordar & 4,33 & 0,41 & 5,74 & 0,52 & 2,17 & 0,03 \\
\hline & Humor & 6,36 & 0,34 & 7,02 & 0,34 & 1,37 & 0,17 \\
\hline & Qualidade sono & 6,39 & 0,41 & 6,45 & 0,42 & 0,11 & 0,91 \\
\hline \multirow{6}{*}{ Quinta-feira } & Horário que sentiu sono & 22:59 & 13,52 & 00:10 & 12,51 & 3,73 & 0,00 \\
\hline & Meio do sono & 4,07 & 1,75 & 4,11 & 1,94 & 0,13 & 0,90 \\
\hline & Facilidade adormecer & 7,79 & 0,41 & 6,82 & 0,41 & 1,66 & 0,10 \\
\hline & Facilidade acordar & 4,32 & 0,46 & 5,60 & 0,46 & 1,94 & 0,06 \\
\hline & Humor & 6,40 & 0,36 & 6,30 & 0,39 & 0,18 & 0,86 \\
\hline & Qualidade sono & 6,25 & 0,39 & 6,35 & 0,42 & 0,17 & 0,87 \\
\hline \multirow{6}{*}{ Sexta-feira } & Horário que sentiu sono & $23: 12$ & 18,46 & $23: 43$ & 20,33 & 1,13 & 0,26 \\
\hline & Meio do sono & 3,35 & 1,35 & 4,46 & 1,41 & 3,85 & 0,00 \\
\hline & Facilidade adormecer & 7,74 & 0,36 & 6,71 & 0,40 & 1,91 & 0,06 \\
\hline & Facilidade acordar & 4,67 & 0,45 & 5,30 & 0,48 & 0,97 & 0,33 \\
\hline & Humor & 6,09 & 0,39 & 6,52 & 0,40 & 0,77 & 0,44 \\
\hline & Qualidade sono & 6,37 & 0,37 & 7,23 & 0,35 & 1,66 & 0,10 \\
\hline \multirow{6}{*}{ Sábado } & Horário que sentiu sono & $23: 55$ & 20,18 & $00: 48$ & 24,17 & 1,68 & 0,10 \\
\hline & Meio do sono & 4,98 & 2,09 & 5,37 & 1,87 & 0,92 & 0,36 \\
\hline & Facilidade adormecer & 7,60 & 0,32 & 7,49 & 0,41 & 0,21 & 0,83 \\
\hline & Facilidade acordar & 5,03 & 0,47 & 5,06 & 0,49 & 0,05 & 0,96 \\
\hline & Humor & 6,76 & 0,39 & 6,89 & 0,40 & 0,24 & 0,81 \\
\hline & Qualidade sono & 6,46 & 0,36 & 9,13 & 2,28 & 1,27 & 0,21 \\
\hline \multirow{6}{*}{ Domingo } & Horário que sentiu sono & $23: 56$ & 20,20 & 00:09 & 28,99 & 0,40 & 0,69 \\
\hline & Meio do sono & 4,51 & 1,90 & 5,98 & 2,49 & 3,23 & 0,00 \\
\hline & Facilidade adormecer & 7,60 & 0,40 & 7,93 & 0,34 & 0,62 & 0,54 \\
\hline & Facilidade acordar & 6,23 & 0,42 & 5,38 & 0,54 & 1,26 & 0,21 \\
\hline & Humor & 7,58 & 0,33 & 6,30 & 0,47 & 2,29 & 0,02 \\
\hline & Qualidade sono & 8,63 & 1,08 & 6,67 & 0,42 & 1,58 & 0,12 \\
\hline
\end{tabular}




\subsection{Padrões temporais da sonolência}

Figura 8. Média e erro-padrão da Escala de Sonolência Karolinska, coletada a cada 3 horas por trabalhadores e não-trabalhadores, Ensino Médio, São Paulo, SP.

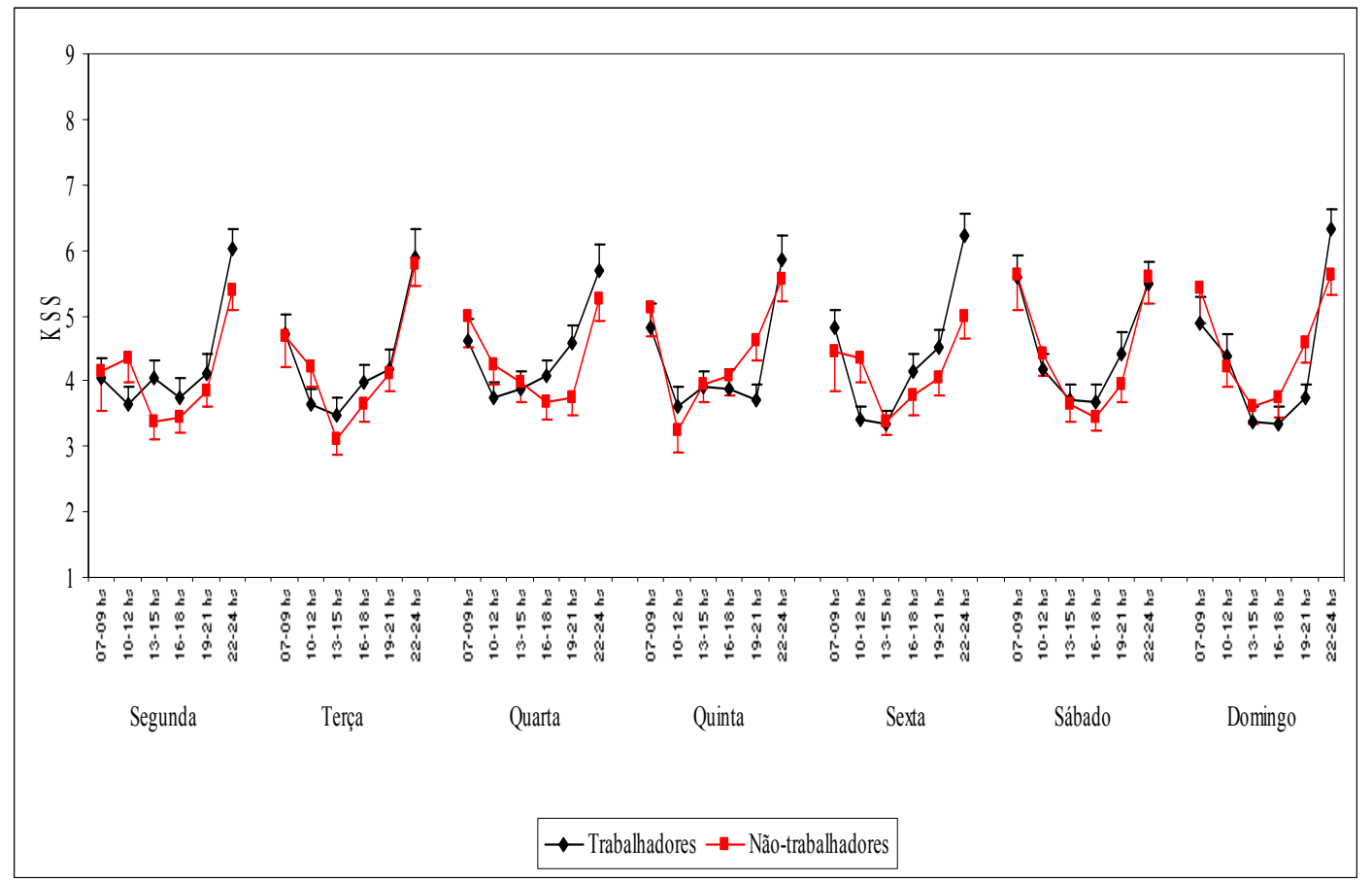

A figura 8 demonstra a média e o erro-padrão da sonolência coletada a cada 3 horas, durante uma semana, pelos estudantes trabalhadores e nãotrabalhadores.

Os padrões de sonolência de estudantes trabalhadores são diferentes dos estudantes não-trabalhadores. Na análise de variância utilizando os fatores grupo (estudantes trabalhadores e não-trabalhadores), dia da semana e horário, foi significante $\mathrm{o}$ fator dia $(4.14 ; \mathrm{p}<0.01)$. A interação do horário e dia $(\mathrm{F}=5.80 ; \mathrm{p}<0.01)$ e grupo, horário e dia $(4.31 ; \mathrm{p}<0.01)$ também foram significantes (Tabela 11). 
Tabela 11. Análise de variância com três fatores para as marcações a cada três horas da Escala de Sonolência Karolinska, durante uma semana.

\begin{tabular}{lllllll}
\hline Fator & $\begin{array}{l}\text { Grau de } \\
\text { liberdade }\end{array}$ & Média & $\begin{array}{l}\text { df } \\
\text { Erro }\end{array}$ & $\begin{array}{l}\text { MS } \\
\text { Erro }\end{array}$ & F & p \\
\hline Trabalho & 1,00 & 72,57 & 90,00 & 21,64 & 3,35 & 0,07 \\
Horário & 5,00 & 6,32 & 450,00 & 6,05 & 1,05 & 0,39 \\
Dia & $\mathbf{6 , 0 0}$ & $\mathbf{1 7 , 0 8}$ & $\mathbf{5 4 0 , 0 0}$ & $\mathbf{4 , 1 3}$ & $\mathbf{4 , 1 4}$ & $\mathbf{0 , 0 0}$ \\
Trabalho e horário & 5,00 & 12,69 & 450,00 & 6,05 & 2,10 & 0,06 \\
Trabalho e dia & 6,00 & 6,66 & 540,00 & 4,13 & 1,61 & 0,14 \\
Horário e dia & $\mathbf{3 0 , 0 0}$ & $\mathbf{2 7 , 5 4}$ & $\mathbf{2 7 0 0 , 0 0}$ & $\mathbf{4 , 7 5}$ & $\mathbf{5 , 8 0}$ & $\mathbf{0 , 0 0}$ \\
Trabalho, dia e horário & $\mathbf{3 0 , 0 0}$ & $\mathbf{2 0 , 4 8}$ & $\mathbf{2 7 0 0 , 0 0}$ & $\mathbf{4 , 7 5}$ & $\mathbf{4 , 3 1}$ & $\mathbf{0 , 0 0}$ \\
\hline
\end{tabular}

Utilizando o teste de Tukey verificamos que os estudantes trabalhadores eram mais sonolentos que os estudantes não-trabalhadores no início $(07+09 \mathrm{~h}) \mathrm{e}$ no fim do dia $(22+24 \mathrm{~h})(\mathrm{p}=0.05)$. Utilizando o teste t-Student verificamos que os estudantes trabalhadores eram mais sonolentos que estudantes não-trabalhadores na segunda-feira após o almoço $(13+15 \mathrm{~h})$, na quarta-feira durante as aulas (19 $21 \mathrm{~h})$ e na sexta-feira antes de dormir (22 - $24 \mathrm{~h})$. Aos domingos, entre 22 - $24 \mathrm{~h}$ foi encontrado o maior nível de sonolência entre os estudantes trabalhadores. Também, neste momento, os trabalhadores eram mais sonolentos que os estudantes não-trabalhadores $(\mathrm{p}<0.01)$. Não foram encontradas diferenças significativas entre os grupos utilizando o sexo e idade como covariáveis.

É importante salientar que o número de observações nos períodos 07 - 09 $\mathrm{h}$ e $22+24 \mathrm{~h}$ são reduzidos devido ao fato que aproximadamente $30 \%$ dos estudantes estavam dormindo nesses momentos. O maior número de respostas no início do dia $(07-09 \mathrm{~h})$ refere-se aos estudantes trabalhadores, e no fim do dia $(22+24 \mathrm{~h})$ aos estudantes não-trabalhadores. 


\section{vigília-sono \\ 5.6 Relação entre a sonolência diurna e as características do ciclo}

A Tabela 12 demonstra um resumo dos principais resultados obtidos a partir da análise de variância para dois fatores (dia da semana e grupo de trabalhadores e não-trabalhadores) e covariáveis relacionadas (duração, eficiência, latência e qualidade do sono, despertares noturnos, facilidade para adormecer e acordar, humor e horário que sentiu sono). A análise completa encontra-se no ANEXO 9.

Fator dia: Foram encontradas diferenças significativas no horário das 07 $09 \mathrm{~h}$ para a facilidade para acordar $(\mathrm{F}=2,13 ; \mathrm{p}=0,05)$ e no horário das $10+12 \mathrm{~h}$ para a latência do sono $(\mathrm{F}=2,82 ; \mathrm{p}=0,01)$. Para os estudantes trabalhadores era mais difícil acordar no domingo e na segunda-feira. No sábado os grupos relataram a mesma facilidade para acordar e nos demais dias era mais difícil para os não-trabalhadores acordarem. Em relação à latência do sono apenas na segunda-feira foram encontradas as maiores médias para os estudantes trabalhadores, nos demais dias a maior latência do sono era dos não-trabalhadores.

Fator dia e trabalho: No horário das $07+09 \mathrm{~h}$ e das $10+12 \mathrm{~h}$ as variáveis eficiência do sono $(\mathrm{F}=2,37 ; \mathrm{p}=0,03)$ e qualidade do sono $(\mathrm{F}=2,32 ; \mathrm{p}=0,03)$ foram significantes. No horário das $10 \vdash 12 \mathrm{~h}$ as variáveis eficiência do sono $(\mathrm{F}=2,66 ; \mathrm{p}=0,02)$, facilidade para adormecer $(\mathrm{F}=2,79 ; \mathrm{p}=0,01)$, facilidade para acordar $(\mathrm{F}=2,68 ; \mathrm{p}=0,01)$ e qualidade do sono $(\mathrm{F}=2,63 ; \mathrm{p}=0,02)$ foram significantes. No horário das $19+21 \mathrm{~h}$ as variáveis horário que sentiu sono $(F=2,39 ; p=0,03)$, eficiência do sono $(F=2,47 ; p=0,02)$, latência do sono $(\mathrm{F}=2,62 ; \mathrm{p}=0,02)$, facilidade para adormecer $(\mathrm{F}=3,25 ; \mathrm{p}=0,00)$, facilidade para acordar $(\mathrm{F}=2,58 ; \mathrm{p}=0,02)$ e qualidade do sono foram significantes $(\mathrm{F}=3,22 ; \mathrm{p}=0,00)$. Para o horário que sentiu sono, apenas na quarta-feira os trabalhadores sentiam sono mais tarde quando comparados com os nãotrabalhadores. A latência do sono era maior na segunda-feira para os estudantes trabalhadores, e nos demais dias, maior para os não-trabalhadores. A eficiência do sono era menor para os estudantes não-trabalhadores na sexta-feira. Nos outros dias da semana os valores eram semelhantes para os grupos. A qualidade do sono 
era semelhante entre os grupos de segunda à quinta-feira. Na sexta-feira e no sábado os trabalhadores relataram pior qualidade do sono ocorrendo o mesmo com os não-trabalhadores no domingo. A facilidade para adormecer era melhor para os trabalhadores de segunda-feira à sábado. Apenas no domingo os estudantes não-trabalhadores relataram maior facilidade para adormecer. A facilidade para acordar era melhor para os trabalhadores de terça à sexta-feira. No sábado não houve diferenças entre os grupos e no domingo os trabalhadores relataram maior dificuldade para acordar.

Sonolência na segunda-feira: Nos horários das $10+12 \mathrm{~h}(\mathrm{~F}=2,53 ; \mathrm{p}=0,03) \mathrm{e}$ das $19+21 \mathrm{~h} \quad \mathrm{~F}=3,28 ; \mathrm{p}=0,01)$ os despertares noturnos foram significantes. Das 13 $15 \mathrm{~h}$ a latência do sono foi significante $(\mathrm{F}=2,94 ; \mathrm{p}=0,01)$. A média dos despertares noturnos era maior para os estudantes não-trabalhadores quando comparados com os trabalhadores. Já a latência do sono era maior para os estudantes trabalhadores quando comparados com os não-trabalhadores.

Sonolência na terça-feira: As variáveis relacionadas ao ciclo vigília-sono dos estudantes não são estatisticamente significantes neste dia da semana.

Sonolência na quarta-feira: No horário das $19+21 \mathrm{~h}$ os despertares noturnos foram significantes $(\mathrm{F}=2,67 ; \mathrm{p}=0,02)$. Neste dia, a maior duração dos despertares noturnos foi verificada para os trabalhadores quando comparados com os não-trabalhadores.

Sonolência na quinta-feira: No horário das $10+12$ h $(\mathrm{F}=2,09 ; \mathrm{p}=0,05)$ e das $19+21 \mathrm{~h}(\mathrm{~F}=2,11 ; \mathrm{p}=0,05)$ a facilidade para adormecer foi significante. No horário das $13+15 \mathrm{~h}(\mathrm{~F}=3,62 ; \mathrm{p}=0,00)$ e das 16 - $18 \mathrm{~h}(\mathrm{~F}=2,94 ; \mathrm{p}=0,01)$ o humor foi significante. Neste dia, os trabalhadores relataram maior facilidade para adormecer quando comparados com os não-trabalhadores. Já a variação no humor foi muito pequena entre os grupos, sendo 6,4 (S.E.=0,36) a média dos trabalhadores e 6,3 (S.E. $=0,39)$ a dos não-trabalhadores.

Sonolência na sexta-feira: No horário das $07+09$ h a eficiência do sono foi significante $(\mathrm{F}=2,37 ; \mathrm{p}=0,03)$. No horário das $22+24 \mathrm{~h}$ a facilidade para 
adormecer $(\mathrm{F}=2,32 ; \mathrm{p}=0,03)$ e acordar $(\mathrm{F}=2,48 ; \mathrm{p}=0,02)$ foram significantes. Neste dia, a eficiência do sono era maior para os trabalhadores quando comparados com os não-trabalhadores. Para os trabalhadores foi relatado maior facilidade para adormecer e maior dificuldade para acordar.

Sonolência no Sábado: No horário das $16+18 \mathrm{~h}$ a facilidade para acordar foi significante $(\mathrm{F}=2,96 ; \mathrm{p}=0,01)$. No horário das $22+24 \mathrm{~h}$ a facilidade para acordar $(\mathrm{F}=2,46 ; \mathrm{p}=0,02)$ e o humor $(3,27 ; \mathrm{p}=0,00)$ foram significantes. A facilidade para acordar foi semelhante para os grupos, sendo 5,03 (S.E.=0,47) a média dos trabalhadores e 5,06 (S.E. $=0,49)$ a média dos não-trabalhadores. Para o humor, os não-trabalhadores eram mais bem humorados.

Sonolência no domingo: No horário das $10+12 \mathrm{~h}$ o horário que sentiu sono foi significante $(\mathrm{F}=2,29 ; \mathrm{p}=0,04)$. No horário das $13+15 \mathrm{~h}$ a eficiência do sono $(\mathrm{F}=2,24 ; \mathrm{p}=0,04)$ e a qualidade do sono $(\mathrm{F}=2,16 ; \mathrm{p}=0,05)$ foram significantes. No horário das $16+18 \mathrm{~h}$ a facilidade para adormecer $(\mathrm{F}=3,91 ; \mathrm{p}=0,00)$ e acordar $(\mathrm{F}=2,97 ; \mathrm{p}=0,01)$ foram significantes. $\mathrm{E}$, no horário das $19+21 \mathrm{~h}$ a facilidade para adormecer foi significante $(\mathrm{F}=2,10 ; \mathrm{p}=0,05)$. No domingo os trabalhadores sentiam sono mais cedo quando comparados com os não-trabalhadores. A eficiência do sono era semelhante para os grupos. A qualidade do sono era melhor para os trabalhadores. Para os trabalhadores foi relatado maior dificuldade para adormecer e maior facilidade para acordar. 
Tabela 12. Tabela-resumo com os resultados da ANOVA para dois fatores (dia e trabalho) e covariáveis relacionadas ao ciclo vigíliasono e escalas visuais analógicas. São demonstradas apenas as associações com $\mathrm{p}<0.05$.

\begin{tabular}{|c|c|c|c|c|c|c|c|c|c|}
\hline Covariáveis & Dia & Segunda-feira & Terça-feira & Quarta-feira & Quinta-feira & Sexta-feira & Sábado & Domingo & Dia x Trabalhar \\
\hline $\begin{array}{l}\text { Horário sentiu } \\
\text { sono }\end{array}$ & & & & & & & & $\begin{array}{c}10-12 \\
(2,29 ; 0,04)\end{array}$ & $\begin{array}{c}19-21 \\
(2,39 ; 0,03) \\
07-09 \\
(2,37 ; 0,03) /\end{array}$ \\
\hline Latência & $\begin{array}{c}10-12 \\
(2,82 ; 0,01)\end{array}$ & $\begin{array}{c}13-15 \\
(2,94 ; 0,01) \\
10-12\end{array}$ & & & & & & & $\begin{array}{c}19-21 \\
(2,62 ; 0,02)\end{array}$ \\
\hline Despertares & & $\begin{array}{c}(2,53 ; 0,03) / \\
19-21 \\
(3,28 ; 0,01)\end{array}$ & & $\begin{array}{c}19-21 \\
(2,67 ; 0,02)\end{array}$ & & & & & \\
\hline $\begin{array}{l}\text { Facilidade para } \\
\text { adormecer }\end{array}$ & & & & & $\begin{array}{c}10-12 \\
(2,09 ; 0,05) / \\
19-21 \\
(2,11 ; 0,05)\end{array}$ & $\begin{array}{c}22-24 \\
(2,32 ; 0,03)\end{array}$ & $16-18$ & $\begin{array}{c}16-18 \\
(3,91 ; 0,00) / \\
19-21 \\
(2,10 ; 0,05)\end{array}$ & $\begin{array}{c}10-12 \\
(2,79 ; 0,01) / \\
19-21 \\
(3,25 ; 0,00) \\
10-12\end{array}$ \\
\hline $\begin{array}{l}\text { Facilidade para } \\
\text { acordar }\end{array}$ & $\begin{array}{c}07-09 \\
(2,13 ; 0,05)\end{array}$ & & & & & $\begin{array}{c}22-24 \\
(2,48 ; 0,02)\end{array}$ & $\begin{array}{c}(2,96 ; 0,01) / \\
22-24 \\
(2,46 ; 0,02)\end{array}$ & $\begin{array}{c}16-18 \\
(2,97 ; 0,01)\end{array}$ & $\begin{array}{c}(2,68 ; 0,01) / \\
19-21 \\
(2,58 ; 0,02)\end{array}$ \\
\hline Humor & & & & & $\begin{array}{c}13-15 \\
(3,62 ; 0,00) / \\
16-18 \\
(2,94 ; 0,01)\end{array}$ & & $\begin{array}{c}22-24 \\
(3,27 ; 0,00)\end{array}$ & & \\
\hline $\begin{array}{l}\text { Qualidade do } \\
\text { sono }\end{array}$ & & & & & & & & $\begin{array}{c}13-15 \\
(2,16 ; 0,05)\end{array}$ & $\begin{array}{c}07-09 \\
(2,32 ; 0,03) / \\
10-12 \\
(2,63 ; 0,02) / \\
19-21 \\
(3,22 ; 0,00)\end{array}$ \\
\hline
\end{tabular}




\subsection{Fatores independentes associados à sonolência}

O Quadro 1 e a Tabela 13 demonstram os principais resultados da análise de regressão logística. O Quadro 1 demonstra as variáveis que são fatores independentes associados à sonolência. A seta para cima indica variáveis com $\mathrm{OR}>2,00, \mathrm{IC}>1 \mathrm{e}$ $\mathrm{p}<0,05$. A seta para baixo indica variáveis com $\mathrm{OR}<1,00$, IC $<1$ e $\mathrm{p}<0,05$. A Tabela 13 demonstra os fatores independentes associados à sonolência para cada dia da semana. A análise de regressão logística para cada dia da semana foi controlada pelas variáveis: trabalho, duração do sono, sexo, faixa etária, fumo, álcool, cafeína e atividade física. A análise completa das análises de regressão para cada dia da semana está no ANEXO 10.

Quadro 1. Resumo da regressão logística para todos os dias da semana.

\begin{tabular}{|c|c|c|c|c|c|c|}
\hline Variável & Categoria & $2^{a}$-feira & $3^{a}-5^{a}$ feira & $6^{\mathrm{a}}$-feira & Sábado & Domingo \\
\hline Trabalha & $\begin{array}{l}\text { Não } \\
\text { Sim }\end{array}$ & & & & $\Uparrow$ & \\
\hline Sexo & $\begin{array}{l}\text { Masculino } \\
\text { Feminino }\end{array}$ & $\Uparrow$ & & & & \\
\hline $\begin{array}{l}\text { Consumo de álcool } \\
\text { ( } \mathrm{g} / \mathrm{kg} / \mathrm{dia})\end{array}$ & $\begin{array}{l}\text { Não bebe } \\
<=0,17 \mathrm{~g} \\
0,18-0,49 \mathrm{~g} \\
0,5-5,0 \mathrm{~g}\end{array}$ & & $\Uparrow$ & & & \\
\hline $\begin{array}{l}\text { Facilidade para } \\
\text { adormecer }\end{array}$ & $\begin{array}{l}7-10 \\
0-6\end{array}$ & & & & $\Uparrow$ & \\
\hline Início do sono & $\begin{array}{l}\text { Até meia-noite } \\
\text { Após meia-noite }\end{array}$ & & & & & $\Uparrow$ \\
\hline
\end{tabular}

Variáveis de controle: trabalho, duração do sono, sexo, faixa etária, fumo, álcool, cafeína e atividade física. 
Tabela 13. Resumo da regressão logística dos fatores independentes associados à sonolência para todos os dias da semana.

\begin{tabular}{|c|c|c|c|c|c|c|c|c|c|c|}
\hline \multirow[t]{2}{*}{ Variável } & \multirow[t]{2}{*}{ Categoria } & & & & \multicolumn{3}{|c|}{$\begin{array}{c}\text { Sem variáveis de } \\
\text { controle }\end{array}$} & \multicolumn{3}{|c|}{ Com variáveis de controle } \\
\hline & & $\mathbf{O R}_{\mathbf{b}}$ & IC $_{95 \%}$ & $\mathbf{p}$ & $\begin{array}{c}\text { OR } \\
\text { aj }\end{array}$ & IC $_{95 \%}$ & $\mathbf{p}$ & $\begin{array}{c}\text { OR } \\
\text { ai }\end{array}$ & IC $_{95 \%}$ & $\mathbf{p}$ \\
\hline \multicolumn{11}{|c|}{ SEGUNDA-FEIRA } \\
\hline Sexo & $\begin{array}{l}\text { Masculino } \\
\text { Feminino }\end{array}$ & $\begin{array}{l}1,00 \\
3,19\end{array}$ & $1,36-7,49$ & 0,01 & $\begin{array}{l}1,00 \\
2,72\end{array}$ & $1,07-6,94$ & 0,04 & $\begin{array}{r}1,00 \\
4,62\end{array}$ & $1,66-12,88$ & $\begin{array}{c}<0,0 \\
1\end{array}$ \\
\hline \multicolumn{11}{|c|}{ TERÇA A QUINTA-FEIRA } \\
\hline $\begin{array}{l}\text { Consumo } \\
\text { de álcool } \\
\text { (g/kg/dia) }\end{array}$ & $\begin{array}{l}\text { Não bebe } \\
<=\mathbf{0 , 1 7 g} \\
0,18-0,49 \mathrm{~g} \\
0,5-5,0 \mathrm{~g}\end{array}$ & $\begin{array}{l}1,00 \\
3,10 \\
0,71 \\
2,04\end{array}$ & $\begin{array}{l}\mathbf{0 , 9 7 - 9 , 9 2} \\
0,22-2,36 \\
0,66-6,34\end{array}$ & $\begin{array}{l}\mathbf{0 , 0 6} \\
0,58 \\
0,22\end{array}$ & & & & $\begin{array}{l}1,00 \\
3,52 \\
0,77 \\
2,31\end{array}$ & $\begin{array}{c}\mathbf{1 , 0 0 - 1 2 , 3 7} \\
0,20-2,92 \\
0,62-8,60\end{array}$ & $\begin{array}{l}\mathbf{0 , 0 5} \\
0,70 \\
0,21\end{array}$ \\
\hline \multicolumn{11}{|c|}{ SEXTA-FEIRA } \\
\hline & & & & & & & & & & \\
\hline \multicolumn{11}{|c|}{ SÁBADO } \\
\hline Trabalha & Não & 1,00 & & & & & & & & \\
\hline Facilidade & $\begin{array}{l}\text { Sim } \\
7-10\end{array}$ & $\begin{array}{l}0,40 \\
1,00\end{array}$ & $0,17-0,94$ & 0,04 & 1,00 & & & $\begin{array}{l}3,19 \\
1,00\end{array}$ & $1,16-8,77$ & 0,02 \\
\hline $\begin{array}{l}\text { para } \\
\text { adormecer }\end{array}$ & $0-6$ & 2,49 & $0,93-6,67$ & 0,07 & 2,49 & $0,93-6,67$ & $\mathbf{0 , 0 7}$ & 4,12 & $1,24-13,73$ & 0,02 \\
\hline \multicolumn{11}{|c|}{ DOMINGO } \\
\hline $\begin{array}{l}\text { Início do } \\
\text { sono }\end{array}$ & $\begin{array}{l}\text { Até meia- } \\
\text { noite } \\
\text { Após meia- } \\
\text { noite }\end{array}$ & $\begin{array}{l}1,00 \\
2,28\end{array}$ & $0,96-5,44$ & 0,06 & $\begin{array}{l}1,00 \\
2,28\end{array}$ & $0,96-5,44$ & 0,06 & $\begin{array}{l}1,00 \\
2,57\end{array}$ & $1,00-6,69$ & 0,05 \\
\hline
\end{tabular}

Variáveis de controle: trabalho, duração do sono, sexo, faixa etária, fumo, álcool, cafeína, atividade física.

1) Fatores associados à sonolência na segunda-feira: Na segunda-feira $28(54,9 \%)$ dos trabalhadores e 19 (46,3\%) dos não-trabalhadores relataram estar sonolentos.

As variáveis que estavam associadas à sonolência foram: ser do sexo feminino $(p=0,01)$ e baixo desempenho escolar $(p=0,03)$.

Fazendo a análise conjunta dos fatores associados, verificou-se que foi fator independentemente associado a estar sonolento na segunda-feira: ser do sexo feminino $(\mathrm{OR}=4,66)$. 
2) Fatores associados à sonolência de terça a quinta-feira: De terça a quinta-feira $25(49,0 \%)$ dos trabalhadores e $17(41,5 \%)$ dos não-trabalhadores estavam sonolentos.

As variáveis que estavam associadas à sonolência foram: duração do estudo fora da escola $\geq 1 \mathrm{~h}(\mathrm{p}=0,04)$.

Fazendo a análise conjunta dos fatores associados, verificou-se que foram fatores independentemente associados a estar sonolento de terça a quinta-feira: beber até $0,17 \mathrm{~g} / \mathrm{kg} /$ dia de álcool $(\mathrm{OR}=3,52)$.

3) Fatores associados à sonolência na sexta-feira: $\mathrm{Na}$ sexta-feira $29(56,9 \%)$ dos trabalhadores e $25(61,0 \%)$ dos não-trabalhadores estavam sonolentos.

Não foram encontrados variáveis que foram fatores associados à sonolência. Fazendo a análise conjunta dos fatores associados, verificou-se que não foram encontrados variáveis que foram fatores associados à sonolência.

4) Fatores associados à sonolência no sábado: No sábado $36(70,6 \%)$ dos trabalhadores e 20 (48,8\%) dos não-trabalhadores estavam sonolentos.

As variáveis que estavam associadas à sonolência foram: trabalhar $(\mathrm{p}=0,04)$, início do sono após meia-noite $(\mathrm{p}=0,03)$ e facilidade para acordar $(\mathrm{p}=0,03)$.

Fazendo a análise conjunta dos fatores associados, verificou-se que foram fatores independentemente associados a estar sonolento no sábado: trabalhar $(\mathrm{OR}=3,37)$ e ter dificuldade para adormecer $(\mathrm{OR}=4,12)$.

5) Fatores associados à sonolência no domingo: No domingo $31(60,8 \%)$ dos trabalhadores e 20 (48,8\%) dos não-trabalhadores estavam sonolentos.

As variáveis que estavam associadas à sonolência foram: duração do tempo livre $>30$ horas semanais $(p=0,004)$ e duração do estudo fora da escola $\geq 2 \mathrm{hs}$ $(p=0,01)$. 
Fazendo a análise conjunta dos fatores associados, verificou-se que ir dormir após a meia-noite $(\mathrm{OR}=2,57)$ foi um fator independentemente associado a estar sonolento no domingo.

As variáveis duração das atividades extracurriculares, das atividades físicas e do transporte, assim como as variáveis relacionadas ao trabalho (local de trabalho, função, salário, acidentes de trabalho e controle no trabalho), hábitos e higiene de sono, IMC e auto-avaliação da saúde não foram associadas à sonolência diurna.

Na Figura 10 encontra-se a súmula dos principais resultados

\subsection{Súmula dos resultados}

Figura 9. Súmula dos resultados relativos à sonolência diurna.
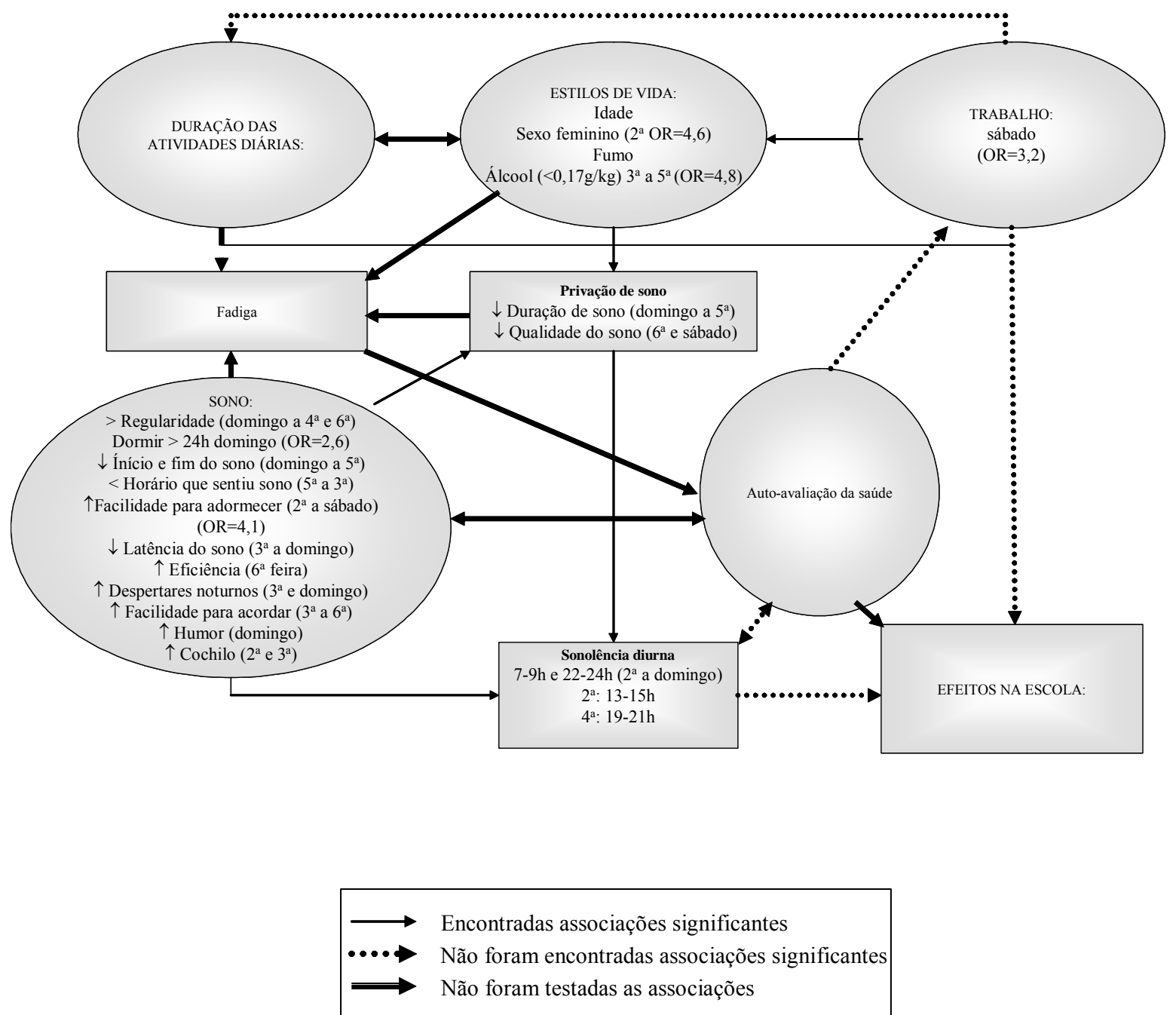


\section{DISCUSSÃO}

A sonolência entre estudantes é um assunto complexo. Por este motivo, a discussão será dividida em blocos. Iniciaremos abordando os fatores sóciodemográficos e continuaremos com os estilos de vida, fatores sociais, fatores relacionados ao ciclo vigília-sono e terminaremos com as diferenças individuais.

\subsection{Diferenças com relação ao sexo}

Neste estudo ser do sexo feminino foi um fator independente associado à sonolência na segunda-feira. Essa associação pode ser explicada pelo acúmulo de atividades realizadas nos fins-de-semana. Além das atividades sociais, muitas adolescentes do sexo feminino auxiliam nos cuidados com a casa e realizam atividades extracurriculares (como cursos de língua inglesa e computação) (TEIXEIRA et al, 2004b). Estudos anteriores demonstraram que as mulheres iniciam o sono e sentem sono mais cedo, e tem maior duração do sono quando comparadas com os homens. Além disso, as jovens têm mais distúrbios de sono durante a adolescência, devido à dificuldade em iniciar o sono, aos despertares noturnos, a pior qualidade do sono e ao se sentir cansada logo após despertar (BEARPARK e MICHIE, 1987; ZEPELIN et al, 1977).

As diferenças na duração do sono em relação ao sexo foram observadas também por ANDRADE, 1991 e LEVY et al, 1986. LEVY et al (1986) verificaram que em todos os grupos de idade, as garotas (12-18 anos de idade) relataram dormir mais horas por semana $(61,2$ horas em média) do que os garotos $(58,6$ horas em média). 


\subsection{Consumo de álcool}

O consumo diário de álcool e café não foi marcado por muitos dos adolescentes no protocolo diário de atividades, então foi utilizado o consumo diário médio de álcool relatado pelos adolescentes no questionário de consumo de cafeína, teobromina e bebidas alcoólicas. Neste estudo, as mulheres não-trabalhadoras relataram maior consumo de bebidas alcoólicas que os outros grupos. Além disso, o consumo médio diário de bebidas alcoólicas relatado pelos estudantes pode ser considerado elevado segundo a OMS (WHO, 2000). HOFFMAN et al (2001) utilizando dados de três estudos populacionais ocorridos na cidade de Nova York em 1983, 1990 e 1994, com estudantes do Ensino Médio demonstraram que as mulheres tinham maior probabilidade de consumir bebidas alcoólicas do que os homens.

É conhecido que o grande consumo de bebidas alcoólicas tem um efeito bifásico no sono. Inicialmente, promovendo a sonolência e o sono, e em seguida, durante a segunda parte do período de sono, interrompendo o sono. Durante o consumo crônico de etanol, o sono é fragmentado, ocorrendo despertares noturnos (ROTH e ROEHRS, 1996). De acordo com ÅKERSTEDT (1996), a sonolência pode piorar devido ao consumo de álcool, ultrapassando sete pontos na escala de sonolência de Karolinska.

Devido aos problemas econômicos e ao estímulo da sociedade em geral e das famílias para o trabalho dos adolescentes, estes podem se sentir pressionados a conseguir um emprego. DOOLEY e PRAUSE (1997) ao analisarem dados do “National Longitudinal Survey of Youth" verificaram que tanto o risco de embriaguez e abuso do álcool aumentou com a precariedade do emprego e o desemprego. 
O consumo de álcool periodicamente traz conseqüências aos jovens, podendo aumentar o risco de problemas sociais e pessoais. Os principais problemas estão relacionados à escola, aos amigos, a polícia, ou então, a aumentar a percepção de que são alcoolistas ou dependentes das drogas (BARNES e WELTE, 1986a). Em outro estudo BARNES e WELTE (1986b) verificaram que os principais fatores que podem levar ao consumo de álcool são: influências durante a socialização com parentes, amigos e namorados(as), bem como os fatores demográficos e problemas de comportamento do adolescente (idade, grupo étnico, proporção de amigos que bebem freqüentemente, atitude dos parentes com relação ao consumo de álcool por crianças e má conduta escolar).

\subsection{Duração do sono}

Em 1973, HARTMANN criou a teoria para restituição do sono explicando quando era necessária maior ou menor duração de sono. A maior duração do sono era necessária para recuperar o corpo e a mente após períodos de estresse, de preocupação, do trabalho cognitivo e emocional, bem como após o trabalho e os exercícios.

Neste estudo, ao compararmos estudantes trabalhadores e não-trabalhadores que freqüentavam as aulas à noite, foram observadas diferenças quanto à duração do sono. Estes resultados corroboram com os achados de vários autores, que demonstram a variação ao longo da semana para a duração do sono dos adolescentes (ALLEN e MIRABLE, 1989; FALLONE et al, 2002; HAWKINS e SHAW, 1991; LEVY et al, 1986; STRAUCH e MEIER, 1988). 
Também verificamos que o horário de dormir e acordar durante a semana são mais tardios para os alunos não trabalhadores. Os estudantes não trabalhadores vão dormir (em média à 1h) e acordam (em média às 9h) mais tarde do que os adolescentes trabalhadores. VINHA et al (2001), também encontraram resultados semelhantes ao analisar o ciclo vigília-sono de estudantes trabalhadores e não trabalhadores que estudavam no período noturno na cidade de Assis-SP. Aparentemente, os estudantes não-trabalhadores possuíam maior liberdade na escolha dos horários de início e fim do sono.

Durante os fins-de-semana, CZEISLER (1997) e VALDEZ et al (1996) sugerem que o atraso de fase representaria a expressão do sistema de temporização da espécie humana e dos fatores psicossociais. Nas situações de enfraquecimento de alguns sincronizadores sociais (trabalho, estudo), o sistema de temporização tenderia a expressar o atraso de fase. Uma outra interpretação para esse fato poderia considerar que nos fins-de-semana, haveria oportunidade de outros tipos de interação social dentro da família, do círculo de amizades e outras atividades de diversão e lazer. Essas possibilidades aliadas ao fato de que não há escola ou trabalho no dia seguinte poderia estender o sono até horários mais tardios, ou em outras palavras, atrasar o fim da fase do sono.

Esta extensão de sono nos fins-de-semana também poderia expressar uma maior privação de sono durante a semana (CARSKADON, 1990). Neste estudo, mesmo com o aumento da duração do sono nos fins-de-semana, a duração do sono durante a semana dos alunos trabalhadores foi em média $2 \mathrm{~h}$ menor do que a dos alunos não-trabalhadores. Os resultados de ANDRADE et al (1993), GAU e SOONG (2003) e STRAUCH e MEIER (1988) demonstram que os adolescentes dormem em 
média 1h30min a menos durante a semana quando comparados aos fins-de-semana. No presente estudo, este fato está relacionado aos alunos trabalhadores acordarem mais cedo ao longo dos dias de trabalho e, portanto, apresentarem menor duração do sono noturno ao longo da semana do que os alunos não-trabalhadores. Enquanto os alunos trabalhadores tenderam a aumentar a duração do sono noturno nos dias de folga, os alunos não-trabalhadores mantiveram similar duração de sono durante a semana e fins-de-semana.

Muitos estudos relatam que a duração do sono nos fins-de-semana é em média 60 minutos a mais que nos dias da semana para crianças com 10 anos de idade; esta diferença na duração aumenta para 90 minutos aos 13 anos de idade, chegando há 3 horas aos 18 anos de idade (CARSKADON, 1990; STRAUCH e MEYER, 1988: WOLFSON e CARSKADON, 1996). De acordo com STRAUCH e MEIER (1988) ao realizar um estudo longitudinal entre 1975 e 1981, verificaram que o desejo de uma maior duração de sono era pronunciado, variando de 54,3\% para $74,5 \%$ no período estudado. Estes resultados demonstram que os adolescentes não obtêm o sono suficiente para satisfazer suas necessidades e possuem uma grande dificuldade de adaptação à redução do tempo total de sono.

\subsection{Regularidade}

Os achados neste estudo mostraram que os adolescentes trabalhadores possuem regularidade nos horários de dormir e acordar durante a semana, sendo a média do meio período do sono em torno das 3:00 h, enquanto o adolescente nãotrabalhador possui a média do meio período do sono próximo às 5:00 h. Do domingo para a segunda-feira a regularidade do sono sofre um arrastamento e o adolescente 
trabalhador tem a média do meio período do sono próximo às 5:00 h e os nãotrabalhadores próximo às 6:00 h. Nossos resultados são semelhantes aos encontrados por BILLIARD et al (1987), que ao estudar jovens trabalhadores do exército, verificou que os fatores independentes associados à sonolência diurna foram: dificuldades de sono, horários irregulares e duração do sono. Para MONK et al (2003) a irregularidade nos horários de dormir e acordar podem ser induzidas por sincronizadores comportamentais no sistema circadiano, como também, ser resultado da privação de sono, onde o indivíduo é forçado a dormir e acordar em diferentes horários ao longo da semana. Neste estudo fica muito claro, que para os adolescentes trabalhadores o trabalho é um forte sincronizador dos horários de dormir e acordar.

\subsection{Eficiência do sono}

Os resultados demonstram que adolescentes trabalhadores demonstram grande eficiência do sono de sexta-feira para sábado quando comparados com nãotrabalhadores. Esses resultados são semelhantes aos encontrados por LEVINE et al (1988) ao comparar um grupo de jovens entre dezoito e vinte e nove anos com um grupo de adultos entre trinta e oitenta anos. Os jovens, principalmente estudantes universitários, são mais sonolentos que adultos mais velhos. Estudantes universitários com elevada eficiência do sono ( $\geq 95 \%)$ mostraram uma latência média diária mais baixa $(8,9 \mathrm{~min})$ do que aqueles com menor eficiência do sono $(\leq 85 \%)$ e maior latência média do sono (14,1 min). A relação entre eficiência do sono noturno e a sonolência diurna sugeriu uma restrição de sono moderada em jovens adultos. 


\subsection{Latência}

$\mathrm{Na}$ segunda-feira foi verificada a maior latência do sono para os estudantes trabalhadores. Provavelmente, os adolescentes trabalhadores atrasam o início e o fim do sono nos fins-de-semana devido às atividades sociais e sentem dificuldade na segunda-feira para adiantar os horários de dormir e acordar. Para o adolescente trabalhador é necessário dormir mais cedo para que acorde descansado e possa enfrentar nova jornada de trabalho. Nos outros dias da semana não foram observadas diferenças significativas entre os grupos de trabalhadores e não-trabalhadores, mas os trabalhadores têm uma média um pouco menor quando comparados com os nãotrabalhadores. FALLONE et al (2002) em seu artigo de revisão demonstra que a diminuição da latência do sono está associada ao aumento da sonolência diurna. CARSKADON et al (1981) e RANDAZZO et al (1998) compararam grupos de sujeitos aos quais era permitido dormir em qualquer horário e grupos de sujeitos aos quais era permitido dormir de 4 a 5 horas por noite. $\mathrm{O}$ grupo privado de sono apresentou menor latência de sono em qualquer momento do dia, aumento significante das medidas subjetivas de sonolência e escores mais baixos em todos os testes cognitivos.

\subsection{Despertares noturnos}

No artigo de revisão de GILLBERG (1995), despertares noturnos maiores que 10 minutos aumentavam a sonolência diurna sem afetar o conteúdo e a duração do sono. Em nosso estudo, verificamos associação da sonolência diurna com os despertares noturnos. Na terça-feira e no domingo, adolescentes trabalhadores têm maior duração média dos despertares noturnos quando comparados com não- 
trabalhadores. Resultados semelhantes foram encontrados por STEPANSKI et al (1984), e STORES et al (1998) ao avaliarem sonolência excessiva, fadiga crônica e cansaço entre jovens.

\subsection{Cochilos}

Os cochilos de acordo com ASCHOFF (1994), podem ter implicações no sono noturno desde que a duração dos cochilos esteja associada com a prévia duração do tempo acordado. Neste estudo a duração dos cochilos apresentou um significante efeito durante os dias da semana. Estudantes trabalhadores tiveram uma duração média maior dos cochilos na segunda e terça-feira quando comparados com os nãotrabalhadores. Os trabalhadores costumam cochilar durante o trabalho e as aulas, e durante o transporte. Durante os fins-de-semana, os trabalhadores tiveram cochilos menores, provavelmente devido aos fatores sociais (lazer e atividades esportivas), mas o débito de sono acumulado durante os dias da semana se manteve. Em estudo anterior, TEIXEIRA et al (2004b) encontrou que adolescentes trabalhadores cochilaram em $45 \%$ dos dias escolares, enquanto não-trabalhadores cochilaram apenas em 16\% dos dias escolares. Nossos resultados não são semelhantes aos publicados por LAWRENCE e SHURLEY, (1972) e VALENCIA-FLORES et al (1998). VALENCIA-FLORES et al (1998) verificaram que somente 16,2\% dos estudantes trabalhadores do México cochilavam, comparados com os nãotrabalhadores (36,9\%). Entre a população mexicana, os estudantes trabalhadores não tinham oportunidade para cochilar. LAWRENCE e SHURLEY, (1972) na Guatemala, também relatou que um grande número de estudantes trabalhavam (79\%), mas que apenas uma pequena proporção dos estudantes cochilava quando comparadas com os estudantes dos Estados Unidos. As diferenças encontradas neste 
estudo e nos conduzidos por LAWRENCE e SHURLEY, (1972) e VALENCIAFLORES et al (1998) demonstraram que múltiplos fatores estão associados aos cochilos.

\subsection{Qualidade do sono}

Foram encontradas diferenças significativas entre a qualidade do sono e a sonolência para os dias da semana e o trabalho. De segunda à quinta-feira não houve diferenças significativas com relação à qualidade do sono relatada pelos dois grupos. Na sexta-feira e no sábado, os trabalhadores relataram pior qualidade do sono, ocorrendo o mesmo para os não-trabalhadores no domingo. Possivelmente as intensas atividades sociais e elevado consumo de bebida alcoólica na sexta-feira e no sábado diminuíram a percepção da qualidade do sono. Compartilham desta opinião MANNI et al (1997) e PILCHER et al (1997). Esses pesquisadores ao verificarem a qualidade do sono de estudantes universitários, que relatavam dormir em média 7 8h por noite, observaram que está mais relacionada a medidas de saúde, bem-estar (balanço afetivo, satisfação com a vida, e sentimentos de tensão, depressão, raiva, fadiga e confusão), sonolência e fadiga, do que a duração do sono. Esta opinião não é compartilhada por HAWKINS e SHAW (1991-1992) que ao pesquisarem a duração e a qualidade de sono subjetiva em estudantes universitários, encontraram diferenças significativas na duração do sono nos dias da semana e fins-de-semana, ocorrendo um aumento na qualidade subjetiva do sono durante os fins-de-semana. Portanto, uma maior duração de sono poderia melhorar a percepção da qualidade do sono. 


\subsection{Humor}

Os estudantes trabalhadores, no domingo, estão mais bem humorados quando comparados com os não-trabalhadores. Provavelmente, devido ao fato de poderem escolher os horários de dormir e acordar livremente. DAHL e LEWIN (2002) discutem a privação de sono e o humor. Para esses autores a privação crônica de sono e a dificuldade para adormecer e acordar podem ser um grande risco para o desenvolvimento de problemas de sono e no humor. Além disso, o desenvolvimento, a regulação do sono, e os horários de dormir e acordar podem ser alterados por problemas comportamentais e/ou emocionais. Para PILCHER e HUFFCUTT (1996) a privação do sono tem um efeito negativo sobre o humor. Além disso, a privação parcial do sono pode ser semelhante à fragmentação do sono, e também ter negativos efeitos sobre o humor. FALLONE et al (2002) demonstra que adolescentes do sexo feminino que atrasam o horário de dormir em 2 horas durante os fins-de-semana possuem pior humor quando comparadas com adolescentes com menor atraso no horário de dormir (1 hora).

\subsection{Sonolência}

O desenvolvimento da sonolência nos grupos estudados parece seguir um padrão regulado pelo aumento da necessidade de sono e o ciclo circadiano (CARSKADON e DEMENT, 1982). O padrão em forma de "U” da sonolência para todos os dias estudados, aparentemente é marcado pela influência circadiana. O rápido aumento da sonolência no período noturno demonstra a necessidade do sono e de acordo com nossos resultados, uma redução do sono entre os adolescentes trabalhadores (CARSKADON e ROTH, 1991). A sonolência coletada em diversos 
dias da semana também demonstra um pico adicional no período da tarde ("postlunch dip"), que possivelmente reflete a queda da temperatura após o almoço (CARSKADON e DEMENT, 1979). Mas na vida real, as medidas de sonolência podem ser reduzidas devido à grande possibilidade dos sujeitos usarem substâncias que alteram a condição de alerta, como o café ou então realizar esforço físico (BROUGHTON, 1982). Portanto, a sonolência pode variar de acordo com as características individuais, como por exemplo, em indivíduos com insônia ou hipersonia, fatores ambientais e genéticos (HEATH et al, 1990; JOHNS, 1994).

$\mathrm{Na}$ segunda-feira, o aumento da sonolência entre trabalhadores está provavelmente associado com as mudanças nos horários de dormir e acordar do fimde-semana. O estudante trabalhador dedica este período para as atividades extracurriculares (cursos de inglês e computação) principalmente aos sábados, porque essas atividades não são bem desenvolvidas nas escolas públicas. Além disso, a prática de atividades físicas e a socialização são concentradas nos fins-de-semana (TEIXEIRA et al, 2004b). Isto pode ser explicado por dois fatores: a) adolescentes não-trabalhadores podem ter menor pressão temporal, expressando o atraso de fase característico da puberdade (CARSKADON et al, 1993); b) adolescentes trabalhadores vão para cama logo que chegam em casa, porque precisam acordar cedo no dia seguinte para ir trabalhar. Portanto, a fadiga devido a dupla jornada trabalhar e estudar associada à sonolência, pode mascarar o atraso de fase característico da puberdade.

Indivíduos submetidos a horários de trabalho ou escolares mais rígidos tenderiam a expressar ritmos com características mais semelhantes (HARRISON e HORNE, 1995). Neste estudo os estudantes trabalhadores possuem um ciclo vigília- 
sono regular quando comparados com os estudantes não-trabalhadores. Os trabalhadores têm uma redução do sono durante todos os dias escolares (cerca de duas horas por dia) quando comparados com os não-trabalhadores. Na revisão feita por GILLBERG (1995), foi observado que uma redução de 2-4 horas por dia na duração do sono noturno reduz o nível de alerta e tem efeito acumulativo. Neste estudo, o efeito acumulativo da privação de sono, entre estudantes trabalhadores, pode ser verificado em todos os dias da semana. Isto poderia explicar as diferenças encontradas nos padrões de sono dos fins-de-semana, onde adolescentes trabalhadores sentem sono mais cedo quando comparados com não-trabalhadores, adiantando o horário de dormir. Além disso, indivíduos submetidos à crônica privação de sono, podem perceber o quão sonolentos se encontram, sentindo dificuldades para expressar seus padrões de sonolência (CLUYDTS et al, 2002; SHEN et al, 2006).

\subsection{Sonolência durante as aulas}

Neste estudo foi verificado que mesmo havendo uma grande diferença na duração média do sono durante os dias da semana, somente na quarta-feira durante as aulas (19 - 21 h) os adolescentes trabalhadores são mais sonolentos que os nãotrabalhadores. Em trabalhos anteriores (CARSKADON et al 1989) observaram que 2 horas de redução na duração do sono noturno de adolescentes entre 14 e 18 anos aumentam os níveis de sonolência durante as aulas e reduzem a percepção do alerta em $32 \%$ dos adolescentes. Uma das possíveis explicações para os resultados obtidos neste estudo é o curto período de tempo na escola. Os adolescentes trabalhadores permaneciam na escola por menor tempo quando comparados com os nãotrabalhadores. Em média, os trabalhadores permaneciam na escola por 2,78 horas em 
média e os não-trabalhadores 3,37 horas (TEIXEIRA et al, 2004b). Normalmente, os trabalhadores chegavam tarde na primeira aula (19:00 horas) e só podiam entrar na escola poucos minutos antes da segunda aula começar (19:50h). Às 20:30h, todos os estudantes iam para o intervalo e retornavam a classe às 21:00 h. Muitas vezes, um dos professores faltava e os estudantes iam para casa antes do término das aulas $(22: 30 \mathrm{~h})$.

Sonolência e fadiga são inevitáveis conseqüências da privação de sono (CARSKADON et al, 1998). São freqüentemente manifestadas através do despertar tardio ou muito cedo, cansaço, cochilos durante as aulas e dificuldades no aprendizado. Desta maneira, estudantes sonolentos ou fatigados provavelmente serão os últimos a tomarem iniciativa quando participarem em tarefas em grupo (DAHL, 1999). Ainda que um adolescente trabalhador não cochile durante as aulas, ele pode experimentar breves lapsos de memória.

Ao se pensar em novos estudos sobre a sonolência, é importante considerar atividades extracurriculares, assim como as atividades sociais. As relações existentes entre o trabalho, a escola, a privação de sono e a sonolência diurna, são assuntos de grande interesse para professores, pedagogos e outros profissionais envolvidos na educação. A dupla jornada para adolescentes trabalhadores pode dificultar a ida a escola e a permanência em todas as aulas. A queixa mais comum manifestada por educadores e especialistas ocupacionais sobre adolescentes trabalhadores envolve problemas associados com o aprendizado escolar, baixo desempenho, perda de concentração, alerta e atenção (FALLONE et al, 2005). Provavelmente, esses problemas são agravados pela privação de sono. Outros problemas enfrentados pelos adolescentes trabalhadores que estudam a noite são a incapacidade de estudar fora do 
horário escolar, faltar às aulas freqüentemente e a evasão escolar, quando comparados aos estudantes não-trabalhadores (FISCHER et al, 2003b).

Apesar das conseqüências da privação de sono sobre a sonolência diurna já terem sido bastante investigadas (CARSKADON et al, 1981), poucos são os estudos que mostram conseqüências sobre o desempenho escolar. Essa dificuldade se deve ao fato de existir muitas variáveis que podem influenciar o desempenho e que dificultam a análise dos dados, principalmente quando os estudos são realizados em pequenas populações.

ALLEN (1992) ao analisar estudantes do Ensino Médio que trabalhavam e GIANNOTTI e CORTESI (1997) ao analisarem estudantes italianos entre 14-20 anos de idade verificaram que as atividades escolares eram prejudicadas quando os estudantes dormiam menos e possuíam irregularidade nos horários de dormir. Esses fatores diminuíam o alerta e aumentavam a sonolência durante as aulas. No presente estudo temos diferenças entre os grupos de trabalhadores e não-trabalhadores com relação à duração de sono e regularidade nos horários de dormir e acordar. Os trabalhadores tinham menor duração do sono e regularidade nos horários de dormir e acordar, ocorrendo o oposto com os não-trabalhadores. Portanto, esses resultados podem indicar que os dois grupos podem ter um baixo rendimento escolar.

As diferentes análises realizadas nesta tese demonstram que a sonolência está associada com variáveis de diferentes naturezas: sexo feminino, trabalhar, consumo de álcool e variáveis do ciclo vigília-sono.

Nas hipóteses iniciais ao delinear esse estudo, o trabalho exerceria um papel central nas repercussões do ciclo vigília-sono e conseqüentemente levaria ao 
aumento da sonolência diurna. Foi uma surpresa verificar que os relatos de sonolência excessiva não se mostraram tão prevalentes como se esperava que fossem. Após as análises verificamos que o trabalho não é o único fator que leva à sonolência diurna. Outros fatores contribuem para a ocorrência da sonolência, o que nos demonstra a complexidade do fenômeno e a complexidade nos processos de intervenção.

\subsection{Limitações do estudo}

Neste estudo foram coletados dados de estudantes de uma única escola pública da cidade de São Paulo. Essa escola possui características sóciodemográficas que podem diferir de outras escolas públicas. Portanto, não se pode esquecer, que os resultados deste estudo, devem ser interpretados apenas para populações da escola analisada. Além disso, esse estudo é do tipo transversal, o qual não permite avaliar a ordem temporal ocorrida entre a sonolência e as outras variáveis estudadas, excluindo-se qualquer inferência causal.

O viés de seleção pode ter ocorrido quando selecionamos indivíduos saudáveis para participarem do estudo. Os sujeitos podem não ter relatado que tinham distúrbios de sono (não detectados pelo questionário de distúrbio de sono e actímetro) e/ou morbidades, como por exemplo, problemas respiratórios, que alteram o ciclo vigília-sono, levando a sonolência diurna. Também não sabemos se indivíduos com distúrbios de sono abandonaram a escola.

Uma outra limitação deste estudo refere-se à possível interferência ao longo das coletas de dados. Os dados de sonolência foram coletados em 2002, 2003 e 2004 e foram comparados seus níveis médios. Não foram encontradas diferenças 
significativas entre os grupos, mas não se pode excluir que tenha havido nas respostas aos protocolos, interferências pela influência dos estudantes com seus colegas que já haviam participado deste estudo.

Duas variáveis que provavelmente estão correlacionadas com a sonolência diurna são estado de saúde e fadiga. Essas variáveis não foram analisadas neste estudo, pois merecem um estudo aprofundado, utilizando-se instrumentos específicos para avaliar as múltiplas dimensões destas variáveis. 


\section{CONCLUSÕES}

1) A duração média do sono nos dias da semana para os estudantes trabalhadores foi em torno de $7 \mathrm{~h}$, enquanto a duração do sono dos não trabalhadores foi em torno de 9h. A duração média dos cochilos, na segunda e terça-feira, é maior para os estudantes trabalhadores e menor na sexta-feira e no domingo quando comparados com os não-trabalhadores. Com relação à regularidade do sono, verificamos que durante os dias da semana o estudante trabalhador possui o sono regular, sendo a média do meio período do sono em torno das 3:00 h, enquanto para o não-trabalhador a média do meio período do sono é próximo às 5:00 $\mathrm{h}$. Do domingo para a segunda-feira a regularidade do sono sofre um arrastamento e o estudante trabalhador tem a média do meio período do sono próximo às 5:00 h e o não-trabalhador próximo às 6:00 h.

2) Os padrões de sonolência de estudantes trabalhadores são diferentes dos não-trabalhadores. Foi verificado que os estudantes trabalhadores são mais sonolentos que os não-trabalhadores no início ( 07 - 09 h) e no fim do dia (22 - 24 h). Os estudantes trabalhadores também são mais sonolentos que não-trabalhadores na segunda-feira após o almoço (13 - $15 \mathrm{~h})$, na quarta-feira durante as aulas (19 $-21 \mathrm{~h}$ ) e na sexta-feira antes de dormir $(22+24 \mathrm{~h})$. Aos domingos, entre $22+24 \mathrm{~h}$ foi encontrado o maior nível de sonolência entre os estudantes trabalhadores. Neste momento, os trabalhadores são mais sonolentos que os não-trabalhadores em todos os outros dias e horários.

3) Com relação à sonolência, segundo dia da semana e trabalho, verificamos que:

a) Para o horário que sentiu sono, apenas na quarta-feira o estudante nãotrabalhador sente sono mais cedo que o trabalhador. Nos outros dias da semana, o estudante trabalhador sente sono mais cedo quando comparado com o nãotrabalhador; 
b) A latência do sono é maior na segunda-feira para os estudantes trabalhadores e nos demais dias são os não-trabalhadores que possuem maior latência do sono;

c) Para a eficiência do sono noturno, apenas da sexta-feira para o sábado, os estudantes trabalhadores apresentaram uma melhor eficiência do sono quando comparados com os estudantes não trabalhadores. Nos outros dias da semana os valores são semelhantes para os grupos;

d) Para os despertares noturnos, os estudantes não-trabalhadores possuem maior média da segunda para a terça-feira quando comparados com os trabalhadores. Da terça para a quarta-feira e do domingo para a segunda-feira, os trabalhadores possuem maior duração dos despertares noturnos quando comparados com os não-trabalhadores;

e) A qualidade do sono é semelhante entre os grupos de segunda à quinta-feira. Na sexta-feira e no sábado os trabalhadores relataram pior qualidade do sono ocorrendo o mesmo com os não-trabalhadores no domingo;

f) A facilidade para adormecer é melhor para os trabalhadores de segunda-feira a sábado. Apenas no domingo os estudantes não-trabalhadores relataram maior facilidade para adormecer;

g) Com relação à facilidade para acordar, é mais fácil para os estudantes trabalhadores acordarem no domingo e na segunda-feira. Na quarta-feira é mais difícil para o trabalhador despertar, e nos demais dias é mais difícil para os nãotrabalhadores acordarem. No sábado os grupos possuem a mesma facilidade para acordar;

h) O humor no sábado é melhor para os não-trabalhadores. No domingo os trabalhadores estão mais bem humorados quando comparados com os nãotrabalhadores.

4) Os fatores independentemente associados a estar sonolento são: trabalhar, ser do sexo feminino, consumir álcool, ter maior dificuldade para adormecer e ir dormir após as $24 \mathrm{~h}$. 
Sumarizando os resultados pode-se afirmar que, os padrões de sonolência de estudantes trabalhadores são diferentes dos não-trabalhadores e as variáveis do ciclo vigília-sono interferem nos níveis de sonolência ao longo do dia. Além dos fatores cronobiológicos outros fatores estão relacionados às mudanças nos níveis da sonolência: a) fatores individuais; b) fatores sociais; c) fatores sócio-demográficos e d) estilos de vida. Essa gama de fatores acaba levando ao aumento da sonolência no início e final do dia para os estudantes trabalhadores, o qual pode interferir no rendimento escolar e prejudicar o desenvolvimento físico e mental característico da adolescência e juventude.

Estudos longitudinais podem trazer importantes informações com relação às conseqüências da sonolência para a saúde e bem-estar dos estudantes trabalhadores, bem como na sua trajetória, desde a entrada no mercado de trabalho e a vida adulta. Programas de intervenção tais como, o conhecimento sobre a higiene do sono e as políticas de inserção social que permitam aos estudantes manter um padrão de vida adequado sem ter que se sujeitar a longas jornadas de trabalho enquanto na adolescência e juventude, devem ser implementados. 


\section{RECOMENDAÇÕES}

Os constantes problemas econômicos no Brasil fizeram com que a sociedade encorajasse os adolescentes e jovens a trabalhar. Deste modo, o trabalho desta população é culturalmente aceito por muitas famílias, tanto das classes populares, quanto para as mais favorecidas economicamente e até mesmo explorado por elas, que consideram ser melhor para a criança e o jovem estar trabalhando do que permanecendo nas ruas, expostos ao crime, marginalidade, dependendo de esmolas e submetendo-se a riscos e atividades laborativas violentas, tal como a prostituição (MINAYO-GOMEZ e MEIRELLES, 1997).

CARSKADON (1991) relata em seu artigo que para a sociedade, os adolescentes necessitam de menor duração de sono, e que os adolescentes desconhecem à fisiologia do ciclo vigília-sono. E, que se não houver o conhecimento sobre os riscos da sonolência excessiva, por muito tempo ainda, um grande número de adolescentes estarão desnecessariamente vulneráveis aos problemas de sono e a trágicos acidentes.

É óbvio que para assegurar que a sonolência excessiva ou fadiga entre os estudantes seja evitada é necessário que educadores utilizem técnicas estimulantes. Como as tarefas escolares são complexas e requerem simultaneamente pensamento abstrato, criatividade, integração e planejamento, devem ser compensadas com estratégias motivadoras (DAHL, 1999). Entretanto, em muitas escolas, a situação oposta é encontrada. Aulas discursivas e atividades monótonas induzem a sensação de sonolência e são um obstáculo ao aprendizado. Nossos dados demonstraram que estudantes trabalhadores têm maiores níveis de sonolência durante o dia e às aulas (TEIXEIRA et al., 2005). Em experimentos onde adolescentes com restrição do sono são submetidos às funções cognitivas, verificou-se que a sonolência induzida pela privação de sono diminui os resultados dos testes (FALLONE et al., 2002). Além disso, a restrição do sono, pelo menos para crianças, tem um rápido efeito negativo nas atividades escolares, segundo avaliação dos professores (FALLONE et al., 2005). 
Segundo MITRU et al. (2002) programas educacionais dedicados à higiene do sono, as conseqüências da privação de sono e a sonolência diurna deveriam ser uma das prioridades dos programas curriculares. Esses programas promoveriam o aprendizado por crianças, adolescentes e jovens de que a adequada duração do sono é crucial para um bom rendimento escolar. Para que esses programas sejam estabelecidos, é necessário que os estudos científicos sobre cronobiologia e sono sejam disseminados entre crianças e adolescentes. Atualmente, há muitos cursos sobre medicina do sono, que poderiam ser cursados por educadores interessados nesta área, principalmente professores de ciência e biologia. Além disso, os impactos do sono sobre o aprendizado e os comportamentos de sono de crianças e adolescentes deveriam ser tópicos de discussão durante as reuniões escolares. Assim, crianças, adolescentes e jovens começariam a entender que a sonolência e a fadiga podem levar aos problemas emocionais, aos distúrbios de sono e ao baixo rendimento escolar. Após a assimilação desse conhecimento, educadores e pais encorajariam crianças e adolescentes a terem uma adequada higiene do sono.

No Brasil já existem publicações voltadas a educadores que são dedicadas ao ensino da cronobiologia e da higiene do sono (LOUZADA e MENNA-BARRETO, 2004). Além desse livro, FISCHER et al. (2005) coordenou a publicação do primeiro livro voltado aos adolescentes, que aborda a saúde no trabalho com uma linguagem voltada aos jovens, e que inclui os aspectos cronobiológicos do ciclo vigília-sono. Com relação às políticas públicas, o Ministério da Saúde (2005) lançou o livro "Diretrizes para Atenção Integral à Saúde de Crianças e Adolescentes Economicamente Ativos". Este guia é utilizado por serviços públicos para padronização da identificação, notificação e proteção das crianças e adolescentes trabalhadores. Neste guia, além da anamnese ocupacional tradicional, há questões relativas à duração do sono nos dias da semana (BRASIL, 2005).

As relações existentes entre o trabalho, a escola, a privação de sono e a sonolência diurna, são assuntos de grande interesse para autoridades, agências nãogovernamentais e o setor privado. O governo e o setor privado deveriam oferecer para os adolescentes e jovens trabalho com jornadas parciais, o que reduziria a privação de sono e promoveria o aprendizado. $\mathrm{O}$ estudante teria oportunidade de ser 
treinado e aprenderia uma profissão e, ao mesmo tempo, teria tempo para as atividades educacionais. Deste modo, o período noturno seria dedicado ao lazer e ao descanso. Além disso, isto poderia aumentar o número de vagas de trabalho e reduzir o desemprego dos adultos, criando profissionais qualificados que quebrariam o "ciclo da pobreza".

Com a criação de políticas públicas voltadas aos efeitos negativos da privação de sono e da sonolência, haveria uma melhora da qualidade de vida da população que já está trabalhando ou que em breve entrará no mercado de trabalho. Como milhões de jovens trabalhadores entram na força de trabalho a cada ano, o tema do sono deveria ser divulgado por pesquisadores, educadores e representantes governamentais. Deste modo, muitas conseqüências negativas poderiam ser evitadas, como a redução da sonolência durante as aulas e no trabalho e a prevenção de acidentes no trabalho. 


\section{REFERÊNCIAS BIBLIOGRÁFICAS}

- Acebo C, Labyak SE, Carskadon MA. Dim light melatonin profiles during constant routines: amplitude and development. Sleep. 2003;26:A113-14.

- Åkerstedt T, Froberg JE. Individual differences in circadian patterns of catecholamine excretion, body temperature, performance and subjective arousal. Biol. Psychol. 1976;4:277-92.

- Åkerstedt T, Gillberg M. Sleep disturbances and shiftwork. In: Reinberg A, Vieux N, Andlauer P, editors. Night and shift work. Biological and Social Aspects (Advances in the Biosciences 30). Oxford: Pergamon Press; 1981; p. 127-137.

- Åkerstedt T, Gillberg M. Subjective and objective sleepiness in the active individual. Intern. J. Neuroscience. 1990;52:29-37.

- Åkerstedt T. Sleepiness as a consequence of shiftwork. Sleep. 1988;11:17-34.

- Åkerstedt, T. Wide awake at odd hours. Stockholm, Swedish Council for Worklife Research. 1996.

- Allen RP, Mirable J. Self-reported sleep/wake patterns for students during the school year from two different senior high schools. Sleep Res. 1989;18:132.

- Allen RP. Social factors associated with the amount of school week sleep lag for seniors in a early starting suburban high school. Sleep Res. 1992;21:114.

- Ambulatory Monitoring, Inc. 1996-2000. ACT Millennium [Computer program manual]. Ardsley, NY USA: Ambulatory Monitoring, Inc. (800) 341-0066, fax: (914) 693-6604.

- Ambulatory Monitoring, Inc. 2001. Action-W version 2.3.01 [Computer program manual]. Ardsley, NY USA: Ambulatory Monitoring, Inc. (800) 341-0066, fax: (914) 693-6604.

- Anders TF, Carskadon MA, Dement WC. Sleep habits of children an the identification of pathologically sleepy children. Child Psychiatry Hum Dev. 1978;9:56-63.

- Andrade MMM, Benedito-Silva AA, Sorahia-Domenice EE, Arnhold IJP, Menna-Barreto L. Sleep characteristics of adolescents: a longitudinal study. J Adolesc Health. 1993;14(5):1-6.

- Andrade MMM, Menna-Barreto L. Diurnal variation in oral temperature, sleepiness and performance of high school girls. Biological Rhythm Res. 1996;27(3):336-42. 
- Andrade MMM. Ciclo vigília/sono de adolescentes: um estudo longitudinal [dissertação de mestrado]. São Paulo: Instituto de Ciências Biomédicas da USP; 1991.

- Andrade MMM. Padrões temporais das expressões da sonolência em adolescentes [tese de doutorado]. São Paulo: Instituto de Ciências Biomédicas da USP;1997.

- Arendt J. Melatonin. Clin Endocrinol. 1988;29:205-29.

- Aschoff, J. On the aging of circadian systems. In: Hiroshige T, Honma K, editors. Evolution of circadian clocks. Sapporo: Hokkaido University; 1994.

- Asmus CIF, Barker SL, Ruzany MH, Meirelles VZ. Riscos ocupacionais na infância e na adolescência: uma revisão. Jornal de Pediatria. 1996;72:203-08.

- Barnes GM, Welte JW. Adolescent alcohol abuse: Subgroup differences and relationships to other problem behaviors. Journal of Adolescent Research. 1986a;1:79-94.

- Barnes GM, Welte JW. Patterns and predictors of alcohol use among 7-12th grade students in New York State. J Stud Alcohol. 1986b;47(1):53-62.

- Bearpark H, Michie P. Changes in morningness-eveningness scores during adolescence and their relationship to sleep/wake disturbances. Chronobiologia. $1987 ; 14: 151$.

- Benedito-silva AA, Menna-Barreto L, Marques N, Terneiro S. A self-assessment questionnaire for the determination of morningness-eveningness types in Brazil. In: Hayes DK, Pauly JE, Reiter RJ (eds.). Chronobiology: its role in clinical medicine, general biology and agriculture. Part B. New York: Wiley-Liss; 1990; p. $89-98$.

- Benoit O, Foret J, Merle B, Reinberg A. Circadian rhythms (temperature, heart rate, vigilance, mood) of short and long sleepers: effects of sleep deprivation. Chronobiologia. 1981;8:341-50.

- Billiard M, Besset A, Zachariev Z, Touchon J, Baldy-Moulinier M, Cadilhac J. Relation of seizure discharges to sleep stages. In: Wolf P, Dam M, Janz D, Dreifuss FE, editors. Advances in epileptology, XVIth Epilepsy International Symposium. New York: Raven Press; 1987; p. 665-70.

- Borbély AA. A two process model of sleep regulation. Human Neurobiology. 1982;1:195-204.

- Borges FNS, Fischer FM. Twelve-hour night shifts of healthcare workers: a risk to the patients? Chronobiology Int. 2003;20(2):351-60.

- Brasil. Conselho Nacional de Saúde. Ministério da Saúde. Decreto lei n. 93.933, de 14 de janeiro de 1987. Resolução 196/96, de 10 de outubro de 1996. Diretrizes 
e normas regulamentadoras de pesquisas envolvendo seres humanos. Diário Oficial da República Federativa do Brasil, Brasília. 12/11/1991.

- Brasil. Constituição da República Federativa do Brasil. Brasília, DF:Senado, 1988.

- Brasil. Ministério da Saúde. Diretrizes para Atenção Integral à Saúde do Trabalhador de Complexidade Diferenciada - Diretriz para a Atenção Integral à Saúde de Crianças e Adolescentes economicamente ativos. 2005

- Braz S, Neumann BRG, Tufik S. Avaliação dos distúrbios de sono: elaboração e validação de um questionário. Revista ABP-APAL. 1987;9(1):9-14.

- Breinbauer C. Youth: Choices and change. Promoting healthy behaviors in adolescents. Washington: PAHO, 2005.

- Broughton, R., 1982. Performance and evoked potential measures of various states of daytime sleepiness. Sleep. 5,S135-146.

- Campos HR, Francischini R. Trabalho infantil produtivo e desenvolvimento humano. Psicologia em Estudo. 2003;8(1):119-29.

- Carskadon MA, Dement WC. Effects of total sleep loss on sleep tendency. Percept Mot Skills. 1979;48(2):495-506.

- Carskadon MA, Dement WC. Nocturnal determinants of daytime sleepiness. Sleep. 1982;5 Suppl 2:S73-81.

- Carskadon MA, Dement WC. Sleep studies on a 90-minute day. Eletroencephalogr. Clin. Neurophysiol. 1975;67:317-26

- Carskadon MA, Harvey H, Dement WC. Sleep loss in young adolescents. Sleep. 1981;4:299-312.

- Carskadon MA, Harvey K, Duke P, Anders TF, Litt IF, Dement WC. Pubertal changes in daytime sleepiness. Sleep. 1980;2(4):453-60.

- Carskadon MA, Mancuso J, Rosekind M. Impact of part-time employment on adolescent sleep patterns. Sleep Res. 1989;18:114.

- Carskadon MA, Roth T. Sleep restriction. In Monk TH, editor. Sleep restriction. Sleep, sleepiness and performance. New York: John Wiley \& Sons; 1991.

- Carskadon MA, Vieira C, Acebo C. Association between puberty and delayed phase preference. Sleep. 1993;16(3):258-62.

- Carskadon MA, Wolfson AR, Acebo C, Tzischinsky O, Seifer R. Adolescent sleep patterns, circadian timing, and sleepiness at a transition to early school days. Sleep. 1998;21(8):871-81. 
- Carskadon MA. Adolescent sleepiness: increased risk in a high-risk population. Alcohol, drugs and driving. 1991;5(4)/6(1):317-28.

- Carskadon MA. Patterns of sleep and sleepiness in adolescents. Pediatrician. 1990;17:5-12.

- Carskadon MA. Sleep difficulties in young people. Arch Pediatr Adolesc Med. 2004;158:597-98

- Ceolim MF. Padrões de atividade e de fragmentação do sono em pessoas idosas [tese de doutorado]. São Paulo: Escola de Enfermagem da USP; 1999.

- Cervini R, Burger, F. O menino trabalhador no Brasil urbano dos anos 80. São Paulo: Cortez; 1996.

- Chipkevitch E. Puberdade e adolescência: aspectos biológicos, clínicos e psicossociais. $1^{\text {a }}$ ed. São Paulo: Roca; 1995.

- Cirelli C. How sleep deprivation affects gene expression in the brain: a review of recent findings. J Appl Physiol. 2002;92:394-400.

- Cluydts R, De Valck E, Verstraeten E, Theys P. Daytime sleepiness and its evaluation. Sleep Med Rev. 2002;6:83-96.

- Cole RJ, Kripke DF, Gruen W, Nava J. Ambulatory monitoring of light exposure comparison of measurements at forehead and wrist. Sleep Res. 1990;19:364.

- Craig CL, Marshall AL, Sjöström M, Bauman AE, Booth ML, Ainsworth BE, Pratt M, Ekelund U, Yngve A, Sallis JF, Oja P, and the IPAQ Consensus Group and the IPAQ Reliability and Validity Study Group. International Physical Activity Questionnaire (IPAQ): 12-country reliability and validity. Med Sci Sports Exerc. 2003;35:1381-395.

- Czeisler CA. Commentary: evidence for melatonin as a circadian phase-shifting agent. J Biol Rhythms. 1997;12:618-23.

- D’Amico RJ. Does employment during high school impair academic progress? Social Educ. 1984;57:2-64

- Dahl RE, Carskadon MA. Sleep and its disorders in adolescents. In: Ferber R, Kryger MH, editors. Principles and Practice of Sleep Medicine in the Child. [S.1.]: W. B. Saunders Company; 1995; p. 19-27.

- Dahl RE, Lewin DS. Pathways to adolescent health sleep regulation and behavior. J Adolesc Health. 2002;31(6 Suppl):175-84.

- Dahl RE. The consequences of insufficient sleep for adolescents: Links between sleep and emotional regulation. Phi Delta Kappan. 1999;80(5):354-359.

- DIEESE / CNTE / OIT. Departamento Intersindical de Estatística e Estudos Sócio-Econômicos/Confederação Nacional dos Trabalhadores em 
Educação/Organização Internacional do Trabalho. O trabalho tolerado de crianças até 14 anos em seis capitais brasileiras. São Paulo; 1996.

- Dinges DF, Kribbs NB. Performing while sleepy: Effects of experimentallyinduced sleepiness. In Monk TH, editor. Sleep. Sleepiness and performance: Human performance and cognition. New York: John Wiley e Sons; 1991; p. 97128.

- Dooley D, Prause J, Effect of underemployment on school-leavers' self-esteem. Journal of Adolescence. 1997 Jun;20(3):243-260.

- Drewnowoski A. Diet image: a new perspective on the Food-Frequency Questionnaire. Nutr Rev. 2001;59:370-4.

- Dunn KA, Runyan MPH, Cohen LR, Schulman MD. Teens at work: a statewide study of jobs, hazards, and injuries. J Adolesc Health. 1998;22:19-25.

- Facchini LA, Fassa AG, Dall'Agnol MM, Maia MDF, Christiani DC. Individuals at risk: the case of child labor. In: Heymann JO, (org). Global inequalities at work. New York: Oxford; 2003.

- Fallone G, Acebo C, Seifer R, Carskadon MA.Experimental restriction of sleep opportunity in children: effects on teacher ratings. Sleep. 2005;1;28(12):1561-7.

- Fallone G, Owens JA, Deane J. Sleepiness in children and adolescents: clinical implications. Sleep Med Rev. 2002;6(4):287-306. Review.

- Fassa AG. Health benefits of eliminating child labor. Geneva, Switzerland: International Labor Organization, 2003.

- Fischer FM (coord.) O trampo, a saúde, o futuro... Trabalho dos adolescentes, problemas e caminhos para uma vida melhor; São Paulo: Faculdade de Saúde Pública da Universidade de São Paulo, Departamento de Saúde Ambiental, 2005.

- Fischer FM, Hofmeister VA, Scatena JC, Bruni AC. Reorganização do trabalho em turno na companhia do metropolitano de São Paulo. In: Anais do Congresso da Associação Nacional de Medicina do Trabalho; 1987. Florianópolis: ANAMT; 1987. v.2, p. 677-92.

- Fischer FM, Martins IS, Oliveira DC, Teixeira LR, Latorre MRDO, Cooper SL. Occupational accidents among middle and high school students of the state of São Paulo, Brazil. Rev Saúde Pública. 2003b;37(3):351-6.

- Fischer FM, Oliveira DC, Nagai R, Teixeira LR, Lombardi-Jr M, Latorre MRDO, Cooper SP. Job control, job demands, social support at work and health among adolescents workers. Rev Saúde Pública 2005;39(2):245-53.

- Fischer FM, Oliveira DC, Teixeira LR, Teixeira MCTV, Amaral MA. Efeitos do trabalho sobre a saúde de adolescentes. Ciência \& Saúde Coletiva. 2003a;8(4):973-84. 
- Fitzgerald ST, Laidlaw AD. Adolescent and work: risks and benefits of teenage employment. AAOHN J. 1995;43:185-9.

- Forastieri V. Children at work. Health and safety risks. ILO Child Labour Collection. Geneva: International Labour Office; 1997.

- Foret J, Benoit O, Royant-Parola S. Sleep schedules and peaktimes of oral temperature and alertness in morning and evening types. Ergonomics. $1982 ; 25: 821-7$.

- Fundação SEADE. Anuário estatístico do Estado de São Paulo: 1996. São Paulo; 1997.

- Gau SF, Soong WT. The transition of sleep-wake patterns in early adolescence. Sleep. 2003;26:449-454.

- Giannotti F, Cortesi F, Sebastiani T, Ottaviano S. Circadian preference, sleep and daytime behaviour in adolescence. J Sleep Res. 2002;11:191-9.

- Giannotti F, Cortesi F. Sleep pattern and daytime functions in Italian Adolescents. In: International Symposium Contemporary perspectives on adolescent sleep; 1997 April 17-20; Marina del Rey, California. [acesso em 22fev 2001]. Disponível em http://www.websciences.org/adolescentsleep/giannotti.htm

- Gibson RS. Principles of nutritional assessment. New York: Oxford University Press; 1990.

- Gillberg M, Kecklund G, Åkerstedt T. Relations between performance and subjective ratings of sleepiness during a night awake. Sleep. 1994;17(3):236-41.

- Gillberg M. Sleepiness and its relation to the length, content, and continuity of sleep. J Sleep Res. 1995;4(S2):37-40.

- Greydanus DE, Patel DR, Luckstead EF, Pratt HD. Value of sports preparticipation examination in health care for adolescents. Med Sci Monit. 2004;10:RA204-14.

- Griefahn B, Bröde P, Blaszkewicz M, Remer T. Melatonin production during childhood and adolescence: a longitudinal study on the excretion of urinary 6hydroxymelatonin sulphate. J Pineal Res. 2003;34:26-31.

- Gupta NK, Mueller WH, Chan W, Meininger JC. Is obesity associated with poor sleep quality in adolescents? Am J Human Biol. 2002;14:762-68.

- Harrison Y, Horne JA. Should we be taking more sleep? Sleep. 1995;18(10):90111.

- Hartmann EL. The Functions of Sleep. New Haven: Yale University Press; 1973.

- Hawkins J e Shaw P. Self-reported sleep quality in college students: a repeated measures approach. Sleep. 1992;15:545-49. 
- Hawkins J, Shaw P. College students sleep more (and enjoy sleep more) on weekends. Sleep Res. 1991;20:122.

- Heath AC, Kendler KS, Eaves LJ, Martin NG. Evidence for genetic influences on sleep disturbance and sleep pattern in twins. Sleep. 1990;13:318-35.

- Hoffman JH, Welte JW, Barnes GM.Co-occurrence of alcohol and cigarette use among adolescents. Addict Behav. 2001 Jan-Feb;26(1):63-78.

- Horne JA, Ostberg O. A self-assesment questionaire to determine morningnesseveningness in human circadian rhythms. Int. J Chronobiology. 1976;4:97-110.

- Hulley SB, Cummings SR. Designing Clinical Research. Baltimore: Williams \& Wilkins; 1988.

- IBGE - Instituto Brasileiro de Geografia e Estatística. Pesquisa Nacional por Amostra de Domicílios: Trabalho Infantil 2001. Rio de Janeiro: Instituto Brasileiro de Geografia e Estatística, 2003. 245 p.

- ILO - International Labour Organization. Occupational health problems of young workers. Geneva: International Labour Organization; 1975.

- ILO - International Labour Organisation. Child labour [governing body paper, 264th Session]. Geneva: ILO; 1995. Doc.GB264/ESP/1.

- ILO - International Labour Organization. Every child counts: New global estimates on child labour. Geneva: International Labour Organization; 2002. April 2002.

- Johns MW. Sleepiness in different situations measured by the Epworth Sleepiness Scale. Sleep. 1994;17:703-10

- Johns MW, Gay TJA, Goodyear MDE, Masterton JP. Sleep habits of healthy young adults: use of a sleep questionnaire. Brit J Prev Soc Med. 1971;25:236-41.

- Karasek R. The job content questionnaire (JCQ): an instrument for internationally comparative assessments of psychosocial job characteristics. J Occup Health Psychology. 1985;3(4):322-55.

- Kleitman, N. Sleep and wakefulness. Chicago: University of Chicago Press; 1963.

- Knauth P, Kieswetter E, Ottman W, Karvonen M, Rutenfranz J. Time-budget studies of policement in weekly or swiftly rotating shift systems. Appl Ergon. $1983 ; 14(4): 247-52$.

- Kolata G. Puberty mystery solved. Science. 1984;223:272.

- Lack L. Delayed sleep and sleep loss in University students. J Am Coll Health. 1986;35:105-10. 
- Lavie P, Scherson A. Ultrashort sleep waking schedule. I - evidence of ultradian rhythmicity in 'sleepability'. Eletroencephalogr. Clin. Neurophysiol. 1981;52(2):163-74.

- Lavie P e Segal LS. 24-h structure of sleepiness in morning and evening persons investigated by the ultra short sep-wake cycle. Sleep. 1989;12(6):522-8.

- Lavie P. To nap, perchance to sleep - ultradian aspects of napping. In: Dinges DF, Broughton RJ, editors. Sleep and Alertness. Chronobiological, behavioral and medical aspects of napping. New York: Raven Press; 1989; p. 99-120.

- Lawrence B, Shurley JT. Comparison of sleep habits of American and Guatemalan students. Sleep Res. 1972;1:95.

- Levine B, Roehrs T, Zorick F, Roth T. Daytime sleepiness in young adults. Sleep. 1988;11(1):39-46.

- Levy D, Gray-Donald C, Leech J, Zvagulis I, Pless B. Sleep patterns and problems in adolescents. J Adolesc Health Care. 1986;7(6):386-89.

- Louzada F, Orsoni A, Mello L, Benedito-Silva AA, Menna-Barreto L. A longitudinal study of the sleep-wake cycle in children living on the same school schedules. Biol. Rhythm. Res. 1996;27(3):390-97.

- Louzada FM, Menna-Barreto L. Relógios Biológicos e aprendizagem. $1^{\mathrm{a}}$ ed. São Paulo: Ed. Instituto Esplan, 2004.

- Louzada FM, Menna-Barreto L. Sleep wake cycle expression in adolescence: influences of social context. Biol. Rhythm Res. 2003;34(2):129-36.

- Machado ERS, Varella VBR, Andrade MMM. The influence of study's schedule and work on the sleep-wake cycle of college students. Biol Rhythm Res. 1998;29:578-84.

- Manber R, Bootzin RR, Acebo C, Carskadom MA. The effects of regularizing sleep-wake schedules on daytime sleepiness. American Sleep Disorders. 1996;19(5):432-41.

- Manni R, Ratti MT, Marchioni E, Castelnovo G, Murelli R, Sartori I, Galimberti CA, Tartara A. Poor sleep in adolescents: a study of 869 17-year-old Italian secondary school students. J Sleep Res. 1997;6:44-9.

- Marcondes E, Setian N, coordenadores. Endocrinologia Pediatrica: Aspectos físicos e metabólicos do recém-nascido ao adolescente. São Paulo: Sarvier; 1989.

- Marques N, Menna-Barreto L. Cronobiologia: princípios e aplicações. São Paulo: Edusp; 1997.

- Marx K. O capital: crítica da economia política. Livro 1: O processo de produção do capital. Rio de Janeiro: Bertrand Brasil; 1996. 
- Matsudo SM, Matsudo VK, Andrade DR, Rocha JR. Physical fitness and time spent watching TV in children from low socioeconomic region. Medicine and Science in Sports and Exercise, 1997;29:S237.

- Mechanic D e Hansell S. Adolescent competence, psychological well-being, and self-assessed physical health. J Health Soc Behav. 1987;28:364-74.

- Mello LC. A influência dos horários escolares sobre a ritmicidade biológica de adolescentes [dissertação de mestrado]. São Paulo: Instituto de Psicologia da USP; 1999.

- Menna-Barreto L, Montagner H, Soussignan R, Koch P. The sleep-wake cycle in 4 - to 14-month old children: general aspects and sex differences. Braz. J. Med. Biol. Res. 1989;22:103-6.

- Mielnik I. O adolescente, a escola e o trabalho. Pediatria Moderna. 1987;23(8):278-91.

- Minayo-Gomez C, Meirelles ZV. Crianças e adolescentes trabalhadores: um compromisso para a saúde coletiva. Cad. Saúde Pública. 1997;13(2):135-40.

- Ministério da Educação. Relatório Final do Exame Nacional do Ensino Médio (ENEM) 2003. Instituto Nacional de Estudos e Pesquisas Educacionais Anísio Teixeira. Brasília. 2004.

- Mitru G, Millrood DL, Mateika JH. The impact of sleep on learning and behavior in adolescents. The Teachers College Record. 2002;104(4):704-726.

- Monk CS, McClure EB, Nelson EE, Zarahn E, Bilder RM, Leibenluft E, Charney DS, Ernst M, Pine DS. Adolescent immaturity in attention-related brain engagement to emotional facial expressions. Neuroimage. 2003;20(1):420-8.

- Monk T, Buysse DJ, Rose LR, Hall JA, Kupfer D. The sleep of healthy people a diary study. Chronobiology Int. 1987;17(1):49-60.

- Monk TH. A visual analogue scale technique to measure global vigor and affect. Psychiatry Res. 1989;27:89-99.

- Montagner H, Restoin A, de Roquefeuil G, Djakovic M. Biological, behavioral and intellectual activity rhythms of the child during its development in different educational environments. In: Touitou Y, Haus E, editors. Biologic rhythms in clinical and laboratory medicine. $2^{\mathrm{a}}$ ed. Berlin: Springer-Verlag; 1994; p. 214-29.

- Moreno CRC, Matuzali L, Carvalho FA, Pasqua IC, Alves R, Lorenzi-Filho G. Truck drivers sleep-wake time arrangements. Biol Rhythm Res. 2003;34:137-43.

- Mortimer JT, Finch MD, Seongryeol R et al. The effects of work intensity on adolescent mental health achievement, and behavioral adjustment: new evidence from a prospective study. Child Devel. 1996;67:1243-61. 
- Nérici IG. Adolescência, o drama de uma idade. Rio de Janeiro: Fundo de Cultura; 1969.

- NIOSH - National Institute for Occupational Safety and Health. Child labor research needs. Recommendations from NIOSH child labor working team. 1997. (DHHS-NIOSH publication $\mathrm{N}^{0}$ 97-143).

- Nutbeam D, Aar L, Catford J. Understanding childrens' health behaviour: the implications for health promotion for young people. Soc Sci Med. 1989;29:31725.

- OIT - Organização Internacional do Trabalho. Trabajo Infantil: Que Hacer? Genebra: OIT; 1996.

- Oliveira DC, Fischer FM, Martins IS, Teixeira LR, Sá CP. Futuro e Liberdade: o trabalho e a instituição escolar nas representações sociais adolescentes. Revista Estudos de Psicologia. Natal. 2001;6(2):245-58.

- OPAS - Organização Panamericana de Saúde. Programa de saúde maternoinfantil. O marco conceptual da saúde integral do adolescente e de seu cuidado. [S.1.]: OPAS, 1990.

- Pasqua IC. Comportamento alimentar e estado nutricional de trabalhadores em turnos: uma abordagem cronobiológica [dissertação de mestrado]. São Paulo: Faculdade de Saúde Pública da USP; 2003.

- Pátkai P. Interindividual differences in diurnal variations in alertness, performance and adrenaline excretion. Acta Physiol. Scand. 1971;81:35-46.

- Pilcher JJ, Ginter DR, Sadowsky B. Sleep quality versus sleep quantity: relationships between sleep and measures of health, well-being and sleepiness in college students. J Psychosomatic Res. 1997;42(6):583-96.

- Pilcher JJ, Huffcutt AI. Effects of sleep deprivation on performance: a metaanalysis. Sleep. 1996;19(4):318-26.

- Pinheiro AB, Lacerda EMA, Benzecry EH, Gomes MCS, Costa VM. Tabela para avaliação de consumo alimentar em medidas caseiras. Rio de Janeiro: UFRJ; 1994.

- Randazzo AC, Muehlbach MJ, Schweitzer PK, Walsh JK. Cognitive fuction following acute sleep restriction in children ages 10-14. Sleep. 1998;21:861-68.

- Reiter RJ. Melatonin, active oxygen species and neurological damage. Drug News Perspect. 1998;11:291-6

- Richter ED, Jacobs J. Work injuries and exposures in children and young adults: Review and recommendations for action. Am J Ind Med. 1991;19:747-69. 
- Robazzi MLCC, Cano MAT, Fávero M. O trabalho da criança e do adolescente no Brasil: acidentes ocupacionais e programas de prevenção existentes. Rev Bras Saúde Escolar. 1996;4(1/2):57-9.

- Roberts RE, Roberts CR e Chen R. Suicidal thinking among adolescents with a history of attempted suicide. J Am Acad Child Adolesc. Psychiatry. 1998;37: 1294-300.

- Roehrs T, Timms V, Zwyghuizen-doorenbs A, Buzenski R, Roth T. Polysomnographic, performance and personality differences of sleepy and alert normals. Sleep. 1990;13(5):395-402.

- Roenneberg T, Kuehnle T, Pramstaller PP, Ricken J, Havel M, guth A, Merrow M. A marker for the end of adolescence. Curr Biol. 2004;R1038-9.

- Roth T, Roehrs TA. Etiologies and sequelae of excessive daytime sleepiness. Clin Ther. 1996 Jul-Aug;18(4):562-76; discussion 561. Review.

- Rowland D, Arkkelin D, Crisler L. Computer-based data analysis: using SPSSx in the social and behavioral sciences. Chicago: Nelson-Hall; 1991.

- Sadeh A. Evaluating night waking in sleep-disturbed infants: a methodological study of parental reports and actigraphy. Sleep. 1996;19(10):757-62.

- Saito MI e Silva LEV. Adolescência: prevenção e risco. Atheneu. São Paulo. 2001.

- Sallis JF, Owen N. Physical Activity \& Behavioral Medicine. Thousand Oaks: Sage Publications; 1999.

- Santana VS, Cooper SP, Roberts RE, Aráujo-Filho JB. Adolescent students who work: gender differences in school performances and self-perceived health. Int J Occup Environ Health. 2005;11:294-301.

- Sarti CA. As crianças, os jovens e o trabalho. In: Westphal M. O compromisso da saúde no campo do trabalho infanto-juvenil: Proposta de atuação. São Paulo: Faculdade de Saúde Pública - USP, 1999; p. 39-43.

- Schill WJ, McCartin R e Meyer K. Youth employment: Its relationship to academic and family variables. J Vocational Behaviour. 1985;26:155-63.

- Shen J, Barbera J, Shapiro CM. Distinghishing sleepiness and fatigue: focus on definition and measurement. Sleep Med Rev. 2006;10:63-76.

- Silva RCR e Malina RM. Nível de atividade física em adolescentes do município de Niterói, Rio de Janeiro, Brasil. Cad Saúde Pública. 2000;1091-7.

- Souza L. Validação da actigrafia nos estudos de sono [dissertação de mestrado]. São Paulo: Departamento de Psicobiologia da Universidade Federal de São Paulo; 1999. 
- Spiegel K, Leproult R, Van Cauter E. Impact of sleep debt on metabolic and endocrine function. Lancet. 1999;354:1435-39.

- Spiegel K, Sheridan JF, Van Cauter E. Effect of sleep deprivation on response to immunization. JAMA. 2002;288:1471-72.

- Stampi C. Evolution, chronobiology, and gunctions of polyphasic and ultrashort sleep: main issues. In: Stampi C (Ed.) Why we nap? Boston: Birkhauser; 1992. 279 p.

- Stepanski, E., Lamphere, J., Badia, P., Zorick, F., Roth, T. Sleep fragmentation and daytime sleepiness. Sleep, 1984, 7: 1826.

- Steriade M, McCormick DA, Sejnowski TJ. Thalamocortical oscillations in the sleeping and aroused brain. Science. 1993;262:679-85.

- Stickgold R, Whidbee D, Schirmer B, Patel V, Hobson JA. Visual discrimination task improvement: a multi-sleep process occurring during sleep. J Cogn Neurosci. 2000;12:246-54.

- Stores G, Fry A, Crawford C. Sleep abnormalities demonstrated by home polysomnography in teenagers with chronic fatigue syndrome. J Psychosom Res. 1998;45:67-76.

- Strauch I, Meier B. Sleep need in adolescents: a longitudinal approach. Sleep. 1988;11(4):378-86.

- Strogatz SH. The mathematical structure of the human sleep-wake cycle. Berlin: Springer-Verlag; 1986. 239p.

- Takeuchi H, Inoue M, Watanabe N, Yamashita Y, Hamada M, Kadota G, Harada T. Parental enforcement of bedtime during childhood modulates preference of Japanese junior high school students for eveningness chronotype. Chronobiology Int. 2001;18:823-29.

- Teixeira LR, Fischer FM, Andrade MMM, Louzada FM, Nagai R. Sleep patterns of day-working, evening high-schooled adolescents of São Paulo, Brazil. Chronobiology Int. 2004a;21(2):239-52.

- Teixeira LR, Fischer FM, Nagai R, Souza LC, Turte SL, Repullo-Jr R, Lowden A . Patterns of sleepiness among high schoolers who work and don't work. Shiftwork International Newsletter. 2005;22:148.

- Teixeira LR, Fischer FM, Nagai R, Turte SL. Teen at work: the burden of a double shift on daily activities. Chronobiology Int. 2004b;21(6):845-858.

- Terman LM, Hocking A. The sleep of school children: its distribution according to age, and its relation to physical and mental efficiency. J Education Psychology (parts I, II and III). 1913;4:138-47,199-208,269-82. 
- Tetsuo M, Poth M, Markey SP. Melatonin metabolite excretion during childhood and puberty. J Clin Endocrinol Metab. 1982;55:311-13.

- Thompson EP. A Formação da Classe Operária Inglesa. Rio de Janeiro: Paz e Terra; 1987.

- Thompson FE, Byers T. Dietary assessment resource manual. American Institute of nutrition. J Nutr. 1994;124:2245S-2317S.

- Thorpy MJ, Korman E, Spielman AJ, Glovinsky PB. Delayed sleep phase syndrome in adolescents. J Adolesc Health Care. 1988;9:22-7.

- Valdez P, Ramírez C, García A. Delaying and extending sleep during weekends: sleep recovery or circadian effect? Chronobiology Int. 1996;13(3):191-98.

- Valencia-Flores M, Castaño VA, Campos RM, Rosenthal L, Resendiz M, Vergara P, Aguilar-Roblero R, Ramos GG, Bliwise DL. The siesta culture concept is not supported by the sleep habits of urban mexican students. J Sleep Res. 1998;7:21-9.

- Van Dongen HPA, Dinges DF. Circadian rhythms in fatigue, alertness, and performance. In: Kryger MH, Roth T, Dement WC, (eds). Principles and practice of sleep medicine. $3^{\text {rd }}$ ed. Philadelphia: W.B. Saunders; 2000. p. 391-99.

- Victora CG, Barros FC, Lima RC, Behague DP, Gonçalves H, Horta BL, Gigante DP, Vaughan JP. The Pelotas Birth cohort Study, Rio Grande do Sul, Brazil, 1982-2001. Cad Saúde Pública. 2003;19(5):1241-56.

- Vieira N. Jovens brasileiros: o conflito entre o estudo e o trabalho e a crise de desemprego [tese de doutorado]. Piracicaba, São Paulo: Escola Superior de Agricultura “Luiz de Queiroz" da USP; 2001.

- Vinha D, Cavalcante JA, Andrade MMM. Sleep wake cycle patterns of worker students. Inc: Program and abstracts of the VI Latin American Symposium of Chronobiology; 2001 May 9-13; Natal - RN. Brazil. 2001. p. 59.

- Waldhauser F, Dietzel M. Daily and annual rhythms in human melatonin secretion: role in puberty control. Ann N Y Acad Sci. 1985;453:205-14.

- Walker MP, Brakefield T, Morgan A, Hobson JA, Stickgold R. Practice with sleep makes perfect: sleep-dependent motor skill learning. Neuron. 2002;35:20511.

- Webb WB, Agnew H. Sleep latencies in human subjects: age, prior wakefulness, and reliability. Psychonomic Science. 1971;24:253-4.

- Webb WB, Agnew Jr HW. Sleep stage characteristics of long and short sleepers. Science. 1970;168:146-7.

- Webb WB. An objective behavioral model of sleep. Sleep. 1988;11(5):488-96. 
- Webb WB. Are short and long sleepers different? Psychol. Rep. 1979;44:259-64.

- Webb WB. Sleep: an experimental approach. New York: Macmillan; 1968.

- Wever RA. Sex differences in human circadian rhythms: intrinsic periods and sleep fractions. Experientia. 1984;40:1226-34.

- WHO - World Health Organization. The World Health Report 2000: Health Systems - Improving Performance. Geneva: WHO; 2000.

- Willett WC. Reproducibility and validity of food-frequency questionnaires. $2^{\text {nd }}$ ed. Oxford: University Press; 1998. Nutritional Epidemiology; p.101-47.

- Wolfson AR e Carskadon MA. Early school start times affect sleep and daytime functioning in adolescents. Sleep Res. 1996; 25: 117.

- Wolfson AR, Carskadon MA. Sleep schedules and daytime functioning in adolescents. Child Dev. 1998;69:875-87.

- Zeitzer JM, Daniels JED, Duffy JF, Kleman EB, Shanahan TL, Dijk Derk-Jan, Czeisler CA. Do Plasma Melatonin Concentrations Decline with Age? Am. J Med. 1999;107:432-36.

- Zepelin H, Hamilton P, Wanzie FJ. Sleep disturbance in early adolescence. Sleep Res. 1977;6:183. 
